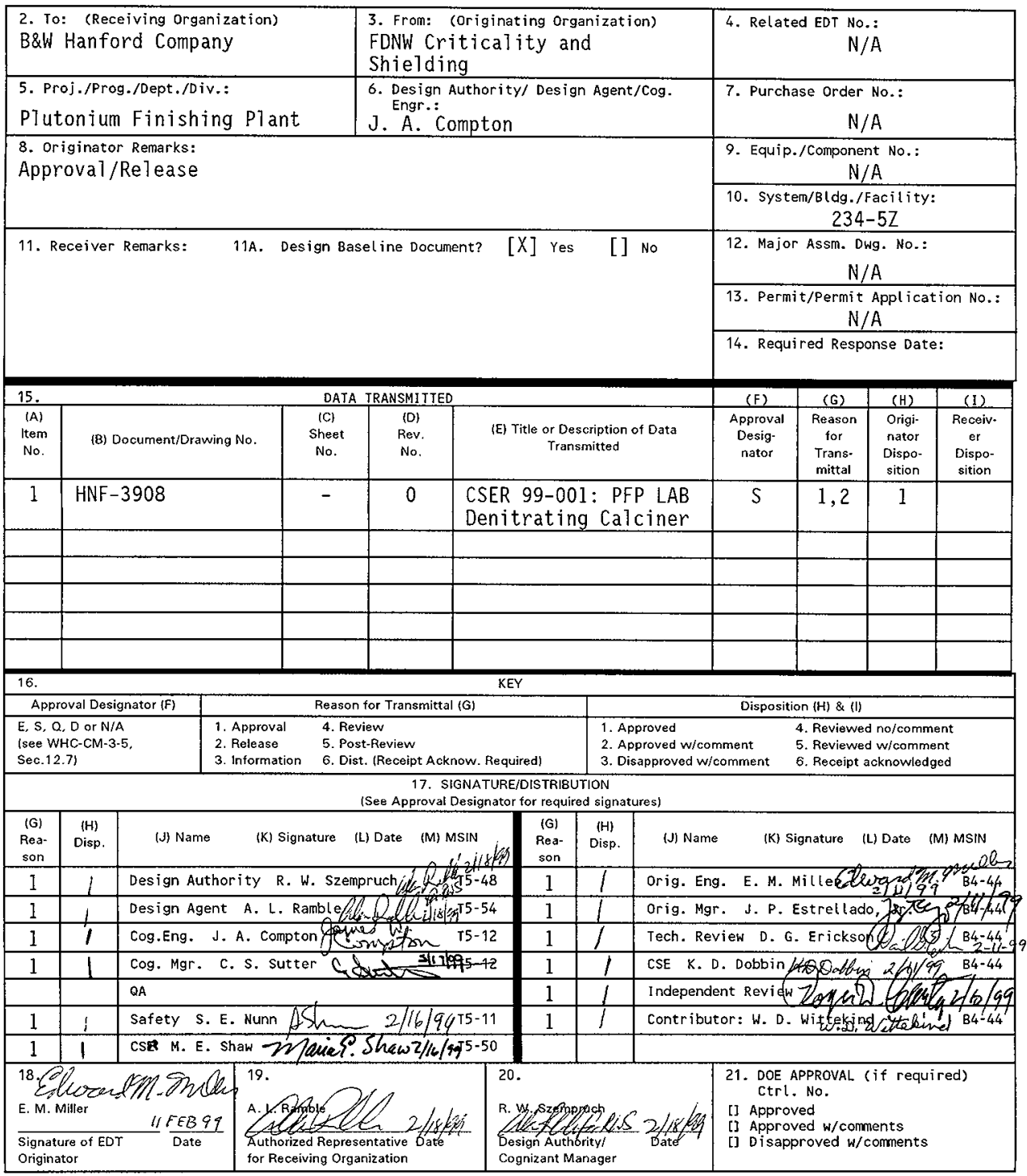


HNF-3908, Rev. 0

\section{CSER 99-001: PFP LAB DENITRATING CALCINER}

E. M. Miller, K. D. Dobbin and W. D. Wittekind

Fluor Daniel Northwest, Richland, WA 99352

U.S. Department of Energy Contract DE-AC06-96RL13200

$\begin{array}{ll}\text { EDT/ECN: } 623022 & \text { UC: } \\ \text { Org Code: } 403 & \text { Charge Code: } 101417 / \mathrm{AJ} 60 \\ \text { B\&R Code: EW7002010 } & \text { Total Pages: } 147 \text { 145 }\end{array}$

Key Words: Calciner, PFP, Criticality Safety Fissile Material

Abstract: A criticality safety evaluation report was prepared for the Plutonium Finishing Plant (PFP) laboratory denitrating calciner, located in Glovebox 188-1, that converts $\mathrm{Pu}\left(\mathrm{NO}_{3}\right)_{4}$ solutions to the high fired stable oxide $\mathrm{PuO}_{2}$. Fissile mass 7 imits and volume 7 imits are set for the glovebox for testing operations and training operators using only nitric acid feed to a plutonium oxide bed in the calciner.

TRADEMARK OISCLAIMER. Reference herein to any specific comercial product, process, or service by trade name, trademark, manufacturer, or otherwise, does not necessarily constitute or imply its endorsement, recomendation, or favoring by the United States Government or any agency thereof or its contractors or subcontractors.

Printed in the United States of America. To obtain copies of this document, contact: Document Control Services, P.O. Box 950, Mailstop H6-08, Richland WA 99352, Phone (509) 372-2420; Fax (509) 376-4989.
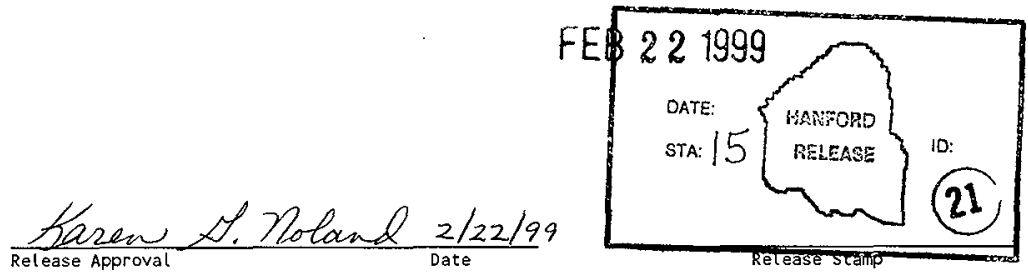


\section{CSER 99-001}

\section{PFP LAB DENITRATING CALCINER}

Prepared by Equarel it. 9 hath

Date: $/ / F E B 99$

E. M. Miller

Criticality and Shielding

Prepared by: $/ 2 \otimes D$ Dofien

K. D. Dobbin

Criticality and Shielding

Prepared by: Warrew D. Wittekind

W. D. Wittekind

Date: //Febwary 1999

Criticality and Shielding

Reviewed by: Said \& z

D.G. Erickson

Date: $2 / 11 / 99$

Criticality and Shielding

Date: $2-11-99$

Approved by:

T.P. Estrellado, Jy., Manager

Date: $02 / 11 / 99$

Criticality and Shielding 
HNF-3908 Rev. 0

This page intentionally left blank. 
HNF-3908 Rev. 0

\section{EXECUTIVE SUMMARY}

CSER 99-001 analyzes the criticality safety of Phase 1, Operation of the Plutonium Finishing Plant (PFP) vertical denitrating calciner in Glovebox 188-1. The Plutonium Process Support Laboratories will operate the glovebox/calciner system which is located in the PFP 234-5Z building. The calciner is to be run with nitric acid feed to check out the calciner operation and train technical personnel to operate it. No new plutonium oxide product is to be made or added to the $4.1 \mathrm{~kg}$ of plutonium oxide already in the calciner. The only other fissile material inventory in the glovebox or room is $17 \mathrm{~g}$ of plutonium in a half liter slip lid can and up to $14 \mathrm{~g}$ of plutonium holdup in the glovebox. This CSER uses a modified hazards analysis to determine the abnormal conditions that can increase reactivity. The purpose of this CSER is to demonstrate that the nitric acid feed operation meets the requirements of HNF-PRO-334, CRITICALITY SAFETY: GENERAL REQUIREMENTS, for operations with more than $15 \mathrm{~g}$ of fissile material. A combination of new calculations and summarizing those in CSER 95-005 (Geiger 1995a) and its addendum (Geiger 1995b) is used to demonstrate conformance to requirements.

This CSER shows that normal conditions, normal plus expected abnormal conditions, and contingencies are within allowables. These results also indicated that only extraordinary changes to the present configuration of less than $4.5 \mathrm{~kg}$ of $\mathrm{Pu}$, all in oxide form inside the calciner, can make a critical configuration. To create a critical configuration, the plutonium would have to be removed from the calciner, dissolved or energetically mixed with water to a lower density than presently expected for calcine, reflected by several inches of water, and confined to a spherical shape to reach criticality. Even the seismic analysis does not project that these conditions could be met. As summarized in the double contingency documentation forms, the contingencies of adding plutonium feed solution, of dissolving the plutonium in the calciner, of dropping the calcine out of the calciner onto the product tray, even if saturated with plutonium solution, of increasing the calcine density, or of bringing in bottles of plutonium solution are all within allowables. Normal operation of the calciner containing $4.5 \mathrm{~kg}$ of plutonium oxide for the nitric acid feed test has large margins of safety and no credible event or casual action could result in a criticality. The analysis in this CSER has shown that the Phase I operations of the calciner with nitric acid feed meets the requirements of HNF-PRO-334. 
HNF-3908 Rev. 0

\section{TABLE OF CONTENTS}

EXECUTIVE SUMMARY iii

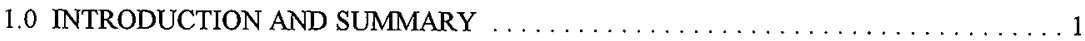

1.1 INTRODUCTION ...............................

1.2 DOUBLE CONTINGENCY DOCUMENTATION $\ldots \ldots \ldots \ldots \ldots \ldots \ldots$

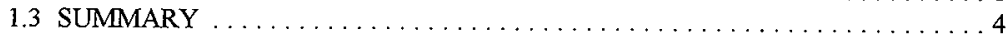

2.0 SYSTEM DESCRIPTION AND NORMAL OPERATIONS $\ldots \ldots \ldots \ldots \ldots \ldots \ldots 4$

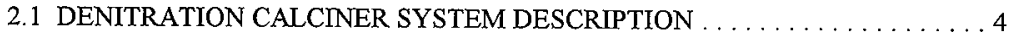

2.1.1 Concentration and Composition of the Fissile Material $\ldots \ldots \ldots \ldots \ldots 4$

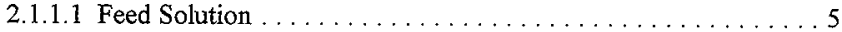

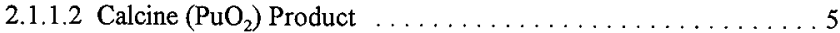

2.1.1.3 Precipitated Pu Solids in Scrubber Tank . . . . . . . . . . . . 5

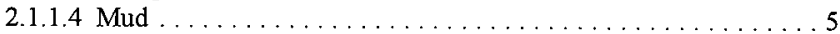

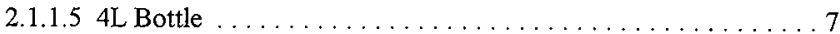

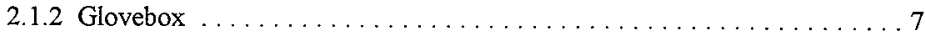

2.1.2.1 Criticality Drain ...................... 8

2.1.2.2 Accumulation of Fissile Material on Glovebox Floor . . . . . 8

2.1.2.3 Water Flooding the Glovebox . . . . . . . . . . . . . . . . .8

2.1 .3 Vertical Calciner . . . . . . . . . . . . . . . . . . . . . . 9

2.1.3. I The Lower Section . . . . . . . . . . . . . . . . . . . . . . 9

2.1.3.2 The Upper Section ....................... 11

2.1.3.3 Product Collection Tube . . . . . . . . . . . . . . . . 11

2.1.3.4 Internal Flooding . . . . . . . . . . . . . . . . . 11

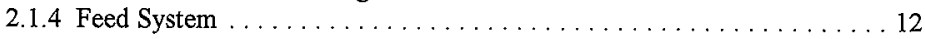

2.1.4.1 Feed Polybottle . . . . . . . . . . . . . . . . . . 12

2.1.4.2 Feed Tank .......................... 12

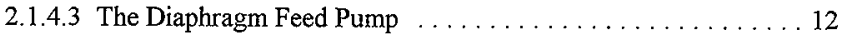

2.1 .5 Scrubber System . . . . . . . . . . . . . . . . . . . . 12

2.1.5.1 Scrubber Tank ........................ . 12

2.1.5.2 Spent Scrubber Receipt Tanks . . . . . . . . . . . . . 13

2.1.5.3 Scrubber Chilled Water Supply .... . . . . . . . . . . . . 13

2.1.5.4 Spent Scrub Solution Vacuum Trap . . . . . . . . . . . . 13

2.1.5.5 Scrubber Solution Supply . . . . . . . . . . . . . . . . 13

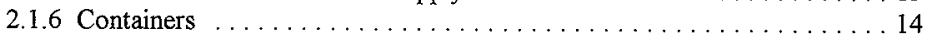

2.1.6.1 The Product Receiver . . . . . . . . . . . . . . . . . 14

2.1.6.2 The Load out Container . . . . . . . . . . . . . . . . 14

2.1.6.3 Other Containers ...................... 14

2.2 NORMAL OPERATION DESCRIPTION $\ldots \ldots \ldots \ldots \ldots \ldots \ldots \ldots \ldots$

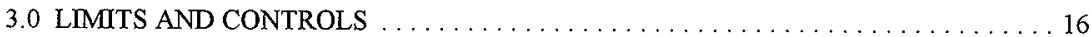

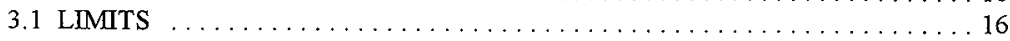

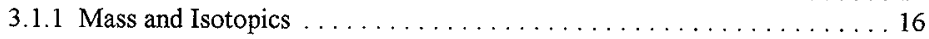

3.1 .2 Moderation ............................. 16 


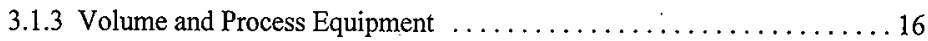

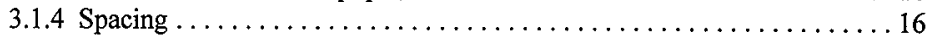

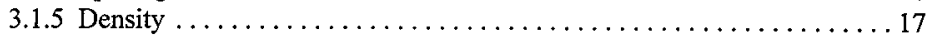

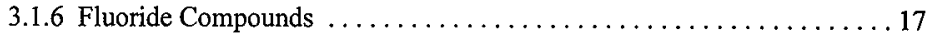

3.1.7 Disassembly of calciner ......................... 17

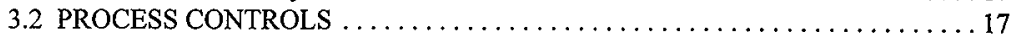

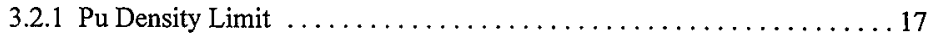

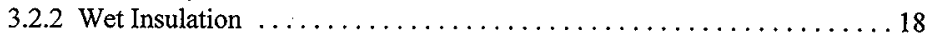

3.2.3 Plutonium Solutions or Plutonium Materials . . . . . . . . . . . 18

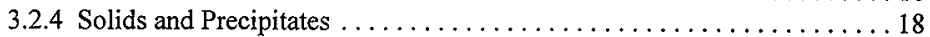

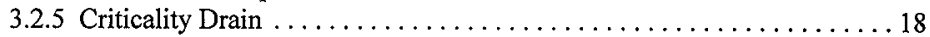

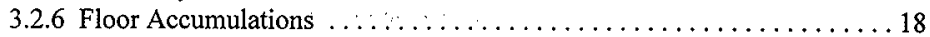

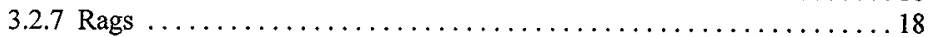

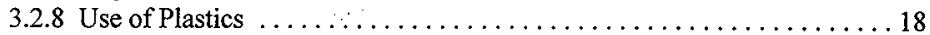

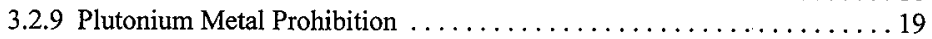

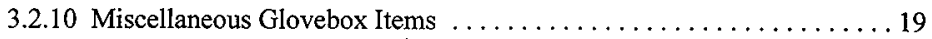

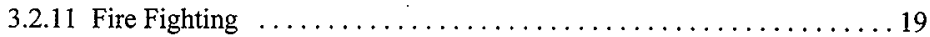

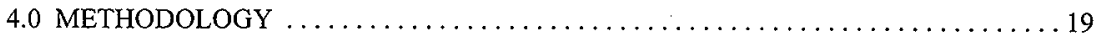

4.1 REQUIREMENTS AND EXEMPTIONS $\ldots \ldots \ldots \ldots \ldots \ldots \ldots \ldots \ldots \ldots \ldots$

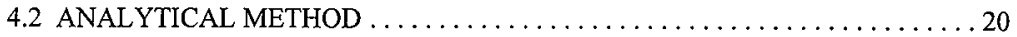

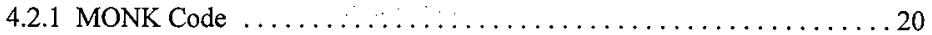

4.2.2 MCNP Code ............................... 20

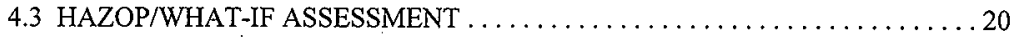

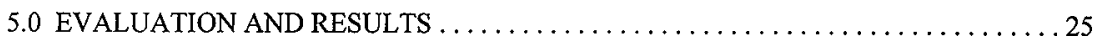

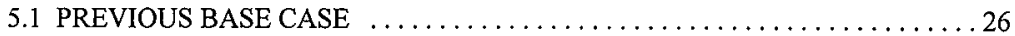

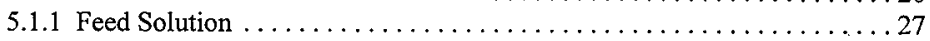

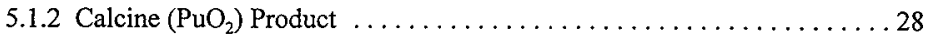

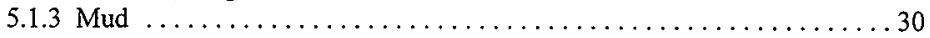

5.1.4 Precipitated Pu Solids in Tanks ....................... 30

5.1 .5 Glovebox ........................................ 30

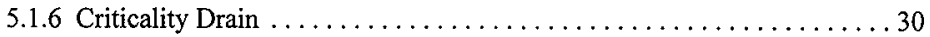

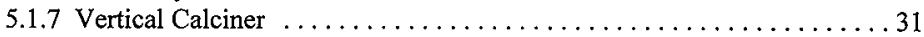

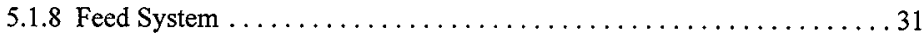

5.1.8.1 Feed Polybottle ........................... 31

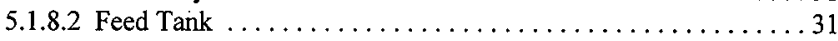

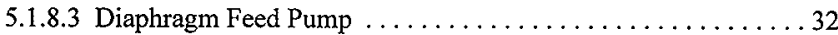

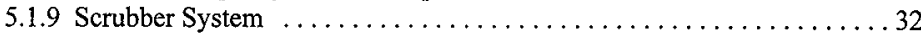

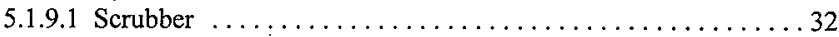

5.1.9.2 Scrub Solution Catch Tanks ...................... 32

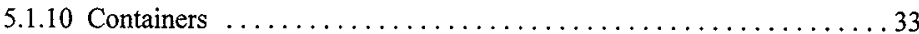

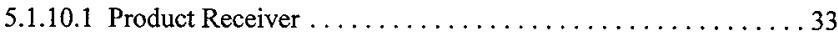

5.1.10.2 Load Out Container. . . . . . . . . . . . . . . . . . 33

5.1 .10 .3 Other Containers . . . . . . . . . . . . . . . . . . . 33

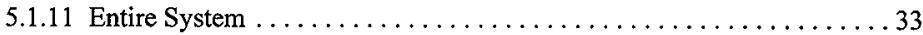




\section{HNF-3908 Rev. 0}

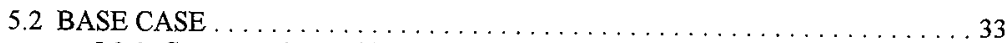

5.2.1 Concentration and isotopic composition of the fissile material . . . . . 34

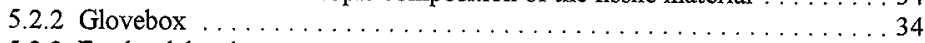

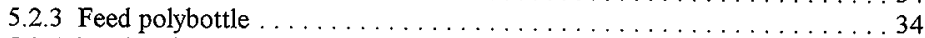

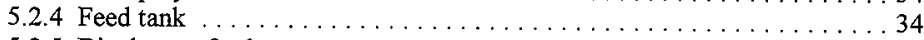

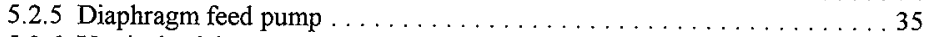

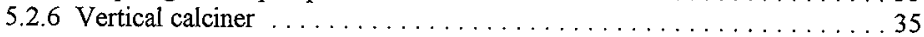

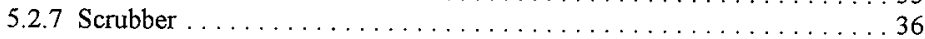

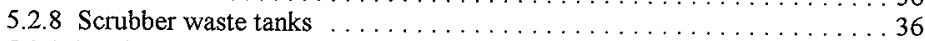

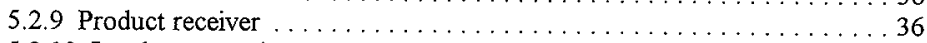

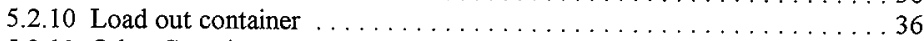

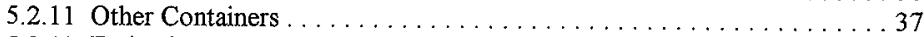

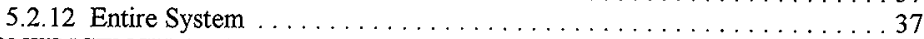

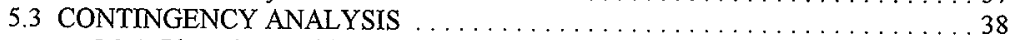

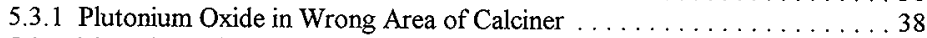

5.3 .2 Plutonium Nitrate Added Instead of Nitric Acid $\ldots \ldots \ldots \ldots \ldots \ldots . \ldots . \ldots$

5.3 .3 Oxide Spill . . . . . . . . . . . . . . . . . . . . . . 39

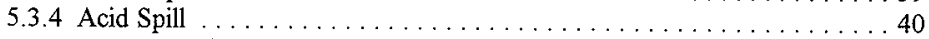

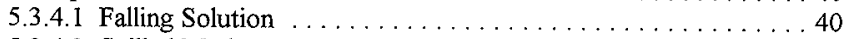

5.3 .4 .2 Spilled Mud . . . . . . . . . . . . . . . . . 40

5.3 .4 .3 Lower Density Mud . . . . . . . . . . . . . . . 41

5.3 .4 .4 Wet Lower Insulation . . . . . . . . . . . . . . . . . 41

5.3.4.5 Spilled Acid Conclusion . . . . . . . . . . . . . . 42

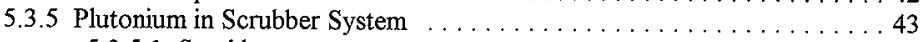

5.3 .5 .1 Scrubber . . . . . . . . . . . . . . . . . . 43

5.3.5.2 Scrub Solution Catch Tanks . . . . . . . . . . . . . 43

5.3.5.3 Scrubber Chilled Water Supply . . . . . . . . . . . . . . 44

5.3.5.4 Spent Scrub Solution Vacuum Trap . . . . . . . . . . . . . 44

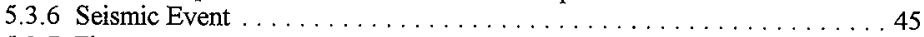

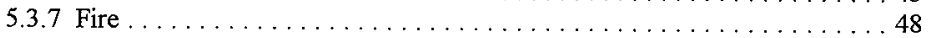

5.3.7.1 Water Ingress into Glovebox . . . . . . . . . . . . 48

5.3.7.2 Fire Fighting Category . . . . . . . . . . . . . . . . . 49

5.3 .8 Criticality Drain $\ldots \ldots \ldots \ldots \ldots \ldots \ldots \ldots \ldots \ldots \ldots . \ldots \ldots$

5.3 .9 Acid Fed Too Quickly $\ldots \ldots \ldots \ldots \ldots \ldots \ldots \ldots \ldots \ldots \ldots \ldots$

5.3 .10 Second $4 \mathrm{~L}$ Bottle of Acid in Glovebox . . . . . . . . . . . . 50

5.3 .11 Plutonium-bearing Drum Brought into Room $188 \ldots \ldots \ldots \ldots \ldots$

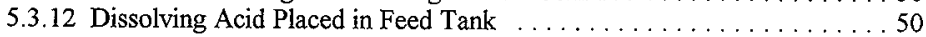

5.3 .13 Oxide Density Exceeded . . . . . . . . . . . . . . . . 51

5.3.13.1 Pu Density Determination . . . . . . . . . . . . . . 51

5.3.13.2 Maximum Calcine Density Expected . . . . . . . . . . 51

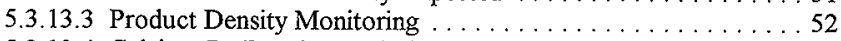

5.3.13.4 Calciner Pu Density Analysis . . . . . . . . . . 52

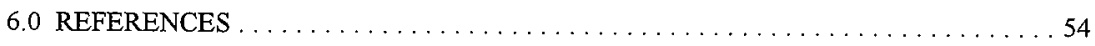

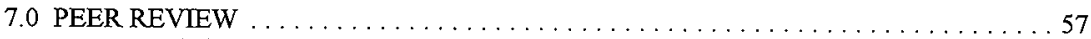

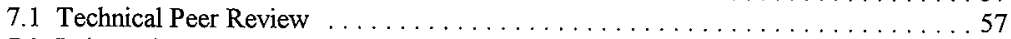

7.2 Independent Technical Peer Review $\ldots \ldots \ldots \ldots \ldots \ldots \ldots \ldots \ldots \ldots$ 
HNF-3908 Rev. 0

APPENDIX A. MCNP 4B COMPUTER CODE VALIDATION

APPENDIX B. MONK6B COMPUTER CODE VALIDATION

APPENDIX C. MCNP INPUT FILES

APPENDIX D. CRITICALITY HAZARDS IDENTIFICATION AND ASSESSMENT D-1

APPENDIX E. SEISMIC MCNP CASE INPUTS E-1

APPENDIX F. CORRESPONDENCE F-1

\section{LIST OF TABLES}

Table 1. PFP Lab Denitrating Calciner, Acid Feed Testing - Base Case Summary . . . . . . . . . 2

Table 2. PFP Lab Denitrating Calciner, Acid Feed Testing - Contingency Summary . . . . . . . . 3

Table 3. Reactivity for Various Forms of "Mud"

Results in this table used $5 \%{ }^{240} \mathrm{Pu}$ and $2 \%{ }^{241} \mathrm{Pu}$ in plutonium

Table 4. Assessment of "PFP Vertical Denitration Calciner."

Activity Assessment Team: Jim Compton, Maria Shaw, Warren Wittekind, Edward

Miller, Ken Dobbin, and Dennis Clapp.

Assessment Conducted: January 16, $1999 \ldots \ldots \ldots \ldots \ldots \ldots \ldots \ldots \ldots \ldots \ldots 21$

Table 5. Controlled Parameters, Controls, Limits and Contingency Analyses . . . . . . . . . 25

Table 6. Previous Base Case Model from CSER 95-005 . . . . . . . . . . . . . . . . . . . . 26

Table 7. Plutonium Isotopic Analysis

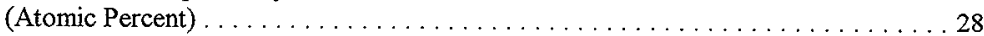

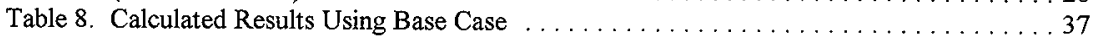

Table 9. Caiciner Filled with Calcine and Flooded with Feed

Lower Insulation Saturated With Water . . . . . . . . . . . . . . . . . . . . . . . . . 39

Table 10. MONK6B Contingency Analysis Results . . . . . . . . . . . . . . . . . . . 40

Table 11. Addendum 1 of CSER 95-005 Contingency Analysis for a Feed Spill ${ }^{1} \ldots \ldots \ldots .42$

Table 12. Calculated $\mathrm{k}_{\text {eff }}$ for $4500 \mathrm{~g}$ of Plutonium in Spherical Geometry,

Fully Water Reflected

Table 13. Calciner Flood with a $6.0 \mathrm{~kg}$ Mass Limit

\section{LIST OF FIGURES}

Figure 1. Prototype Calciner Glovebox $188-1 \ldots \ldots \ldots \ldots \ldots \ldots \ldots \ldots \ldots \ldots \ldots \ldots \ldots$

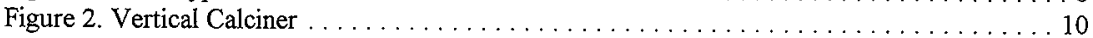

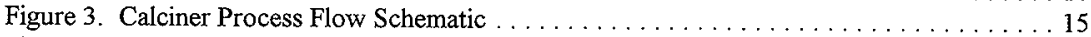

Figure 4. Effective Multiplication Factor, $\mathrm{k}_{\mathrm{eff}}$, vs. Plutonium Oxide Density.

Fully Reflected Spherical Geometry - Water Penetrates All Void Space in Oxide . . . 46

Figure 5. Effective Multiplication Factor, $\mathrm{k}_{\mathrm{eff}}$, vs. Hydrogen-to-Plutonium Atom Ratio.

Fully Reflected Spherical Geometry - Water Penetrates All Void Space in Oxide . . . 48 
HNF-3908 Rev. 0

This page intentionally left blank. 
HNF-3908 Rev, 0

\subsection{INTRODUCTION AND SUMMARY}

\subsection{INTRODUCTION}

The vertical denitrating calciner in Glovebox 188-1, which is located in Room 188 in the PFP 234-5Z building, is run by the Plutonium Process Support Laboratories. This CSER is to cover operation of the calciner with nitric acid feed to check out the calciner operation and train technical personnel to run the calciner. No fissile material is to be added to the $4.1 \mathrm{~kg}$ of plutonium oxide already in the calciner, glovebox, or room. The only other fissile material inventory in the glovebox or room is $17 \mathrm{~g}$ of plutonium in a half liter slip lid can and up to $14 \mathrm{~g}$ of plutonium holdup in the glovebox (Hieb 1995). This CSER uses a modified hazards analysis to determine the abnormal conditions that can increase reactivity. The purpose of this CSER is to demonstrate that the nitric acid feed operation meets the requirements of HNF-PRO-334 (FDH 1997a) for operations with more than $15 \mathrm{~g}$ of fissile material. A combination of new calculations and summarizing those in CSER 95-005 (Geiger 1995a) and its addendum (Geiger 1995b) is used to demonstrate conformance to requirements.

\subsection{DOUBLE CONTINGENCY DOCUMENTATION}

This section presents a summary description of expected operations, expected normal conditions, base case of normal conditions plus expected off-normal conditions. The results of the contingency analyses are presented in Table 2 .

\section{Expected Operation:}

For Phase I calciner operation, equipment will be started and system operation checked using non-fissile bearing nitric acid solution. Pumps, heaters, stirrer, airflow, interlock, scrubber, and filter backflow will be operated. Nitric acid will be injected into the hot powder bed from below via the feed tank, pump and nozzle as the plutonium oxide already present in the powder bed is stirred. Offgas will be processed in the scrubber system.

\section{Expected Normal Conditions:}

The powder bed in the lower calciner annulus contains less than $4.1 \mathrm{~kg}$ plutonium as plutonium oxide and is limited to not more than $4.5 \mathrm{~kg}$. There are 17 grams of plutonium in one of four $0.5 \mathrm{l}$ containers and up to $14 \mathrm{~g}$ of holdup in Glovebox 188-1. Nitric acid will be brought into the glovebox in a $4 \mathrm{~L}$ bottle, maintaining $25.4 \mathrm{~cm}$ (10 in.) spacing from plutonium-bearing components, and poured into the feed tank, located $40.6 \mathrm{~cm}$ (16 in.) from the calciner. The nitric acid is fed into and oxidized in a hot calciner using a diaphragm feed pump. Off-gases are drawn into a scrubber system containing a water-based neutralizing solution. No additional plutonium-bearing compounds are to be brought into Room 188, but there may be plutonium stored in adjacent rooms and the hallway. An extremely conservative estimate of the reactivity for the normal condition is the first of two base cases, presented in Section 5.1 , that used calcine at $5 \mathrm{~g} \mathrm{Pu} / \mathrm{cm}^{3}$ and filled all tanks with $140 \mathrm{~g} \mathrm{Pu} / \ell$ to calculate a $\mathrm{k}_{\mathrm{eff}}$ of 0.815 . The plutonium solution used in this case is a conservatism, not a normal condition. 
HNF-3908 Rev. 0

\section{Base Case Conditions:}

The calciner is filled with $5.5 \mathrm{~g} \mathrm{Pu} / \mathrm{cm}^{3}$ plutonium as plutonium oxide at $\mathrm{H} / \mathrm{X}=2$. The filtering, upper, section of the calciner has a volume of $4.2 \ell$ available to the calcined powder, and can therefore contain $23.1 \mathrm{~kg}$ of plutonium at $5.5 \mathrm{~g} \mathrm{Pu} / \mathrm{cm}^{3}$. The calcination, lower, section has an available volume of $2 \mathrm{l}$ and a capacity of $11 \mathrm{~kg}$. Therefore, the calciner can hold a total of $34.1 \mathrm{~kg}$ of calcined plutonium. There are four $0.5 \ell$ polyjars containing less than $100 \mathrm{~g}$ plutonium at $\mathrm{H} / \mathrm{X}=20$ among them as oxide. The feed tank and $4 \mathrm{~L}$ bottle will contain at least $5.2 \ell$ and $4.2 \ell$, respectively, of nitric acid. The scrubber and scrubber tanks will contain water. A water saturated insulation will surround the lower region of the calciner and damp metal insulation (10\% steel, $10 \%$ water) surrounds the upper section. The entire calciner and its insulation are surrounded by a $2.54 \mathrm{~cm}(1 \mathrm{in}$.) water reflector. The other plutonium-bearing containers also are surrounded with $2.54 \mathrm{~cm}$ (1 in.) of water. The glovebox will have $30.4 \mathrm{~cm}$ ( $12 \mathrm{in}$.) of water reflection on all sides with $2.54 \mathrm{~cm}$ ( $1 \mathrm{in}$.) water reflection top and bottom. Table 1 summarizes the base case conditions. An extremely conservative base case model is described in Section 5.2. This model which included calcine at $5.5 \mathrm{~g} \mathrm{Pu} / \mathrm{cm}^{3}$ and filled all tanks with $140 \mathrm{~g} \mathrm{Pu} / \ell$ solution, resulted in a $\mathrm{k}_{\mathrm{eff}}$ of 0.88 .

\begin{tabular}{|c|c|c|}
\hline $\begin{array}{l}\text { Controlled } \\
\text { Parameter }\end{array}$ & Limit & $\begin{array}{l}\text { Abnormal but Anticipated } \\
\text { Conditions (Conservatism for } \\
\text { Analysis) } \\
\end{array}$ \\
\hline Mass & $4.5 \mathrm{~kg} \mathrm{Pu}$ & \\
\hline Volume & $\begin{array}{l}\text { One } 4 \mathrm{~L} \text { bottle, Four } 0.5 \text { \& polyjars, } 750 \mathrm{~m} \ell \text { of } \\
\text { maintenance fluids, twenty } 30 \mathrm{~m} \ell \text { sample bottles }\end{array}$ & \\
\hline Moderation & $\begin{array}{l}\mathrm{H} / \mathrm{X}=2 \text { for calcine, } \\
\mathrm{H} / \mathrm{X}=20 \text { in sweeps } \\
\text { No fissile solution added to calciner }\end{array}$ & \\
\hline Interaction & $\begin{array}{l}\text { Minimum } 25.4 \mathrm{~cm}(10 \mathrm{in} .) \text { spacing between } \mathrm{Pu} \\
\text { bearing containers and other Pu containers and } \\
\text { process equipment (and Section 3.1.4) }\end{array}$ & \\
\hline Reflection & $\begin{array}{l}30.4 \mathrm{~cm} \text { (12 in.) water around glovebox and } \\
2.54 \mathrm{~cm} \text { ( } 1 \text { in.) water around containers. } \\
\text { Criticality drain visibly unobstructed } \\
\text { Metal skirt covering insulation in place }\end{array}$ & $\begin{array}{l}\text { Nitric acid feed bottle is } \\
\text { modeled adjacent to calciner }\end{array}$ \\
\hline Geometry & $\begin{array}{l}\text { Equipment and plutonium bearing containers } \\
\text { diameter } 15.2 \mathrm{~cm} \text { ( } 6 \text { in.) nominal or less }\end{array}$ & \\
\hline Enrichment & $\begin{array}{l}\text { Minimum } \mathrm{Pu}-2403 \% \\
\text { Maximum } \mathrm{Pu}-241 \mathrm{1} / 5 \text { of } \mathrm{Pu}-240\end{array}$ & \\
\hline Density & $5.5 \mathrm{~g} \mathrm{Pu} / \mathrm{cm}^{3}$ & \\
\hline Concentration & N/A & \\
\hline Poisons & $\mathrm{N} / \mathrm{A}$ & \\
\hline
\end{tabular}




\section{Contingency Summary:}

Table 2 summarizes the analysis of contingencies that challenge the barriers to criticality for each of the standard criticality parameters. The table references the sections in this CSER that presents the analysis. For the nitric acid run, there are no credible contingencies involving enrichment.

\begin{tabular}{|c|c|c|c|}
\hline $\begin{array}{l}\text { Contingeney } \\
\text { Description }\end{array}$ & $\begin{array}{l}\text { Affected } \\
\text { Paraneter(s) }\end{array}$ & $\begin{array}{l}\text { Barrers That Make Contingency } \\
\text { Unilkely }\end{array}$ & $\begin{array}{l}\text { K.p Bounding } \\
\text { Contingeney (ease IO) }\end{array}$ \\
\hline $\begin{array}{l}\text { Plutonium oxide in } \\
\text { wrong area of } \\
\text { calciner }\end{array}$ & Geometry & $\begin{array}{c}\text { Equipment design; gravity } \\
\qquad\end{array}$ & $\mathrm{k}_{\mathrm{eff}}=0.88$ (Note 1$)$ \\
\hline $\begin{array}{l}\text { Nitric acid fed to cold } \\
\text { calciner, or fed to } \\
\text { calciner too quickly } \\
\text { or through relief port }\end{array}$ & Moderation & $\begin{array}{l}\text { Equipment interlock; operator training; } \\
\text { operations procedures }\end{array}$ & $\mathrm{k}_{\mathrm{eff}}=0.91($ Note 2$)$ \\
\hline $\begin{array}{l}\text { Plutonium nitrate } \\
\text { added instead of } \\
\text { nitric acid }\end{array}$ & Mass & Mass limit; operator training & $\mathrm{k}_{\mathrm{cff}}=0.88$ (Note 1) \\
\hline $\begin{array}{l}\text { Spill wets calciner } \\
\text { insulation }\end{array}$ & Reflection & $\begin{array}{l}\text { Operator training; skirting prevents } \\
\text { significant moisture wetting insulation }\end{array}$ & $\mathrm{k}_{\mathrm{eff}}=0.88($ Note 1$)$ \\
\hline $\begin{array}{l}\text { Significant plutonium } \\
\text { in scrubber system }\end{array}$ & Interaction & $\begin{array}{l}\text { Requires filter failure, failure to observe } \\
\text { scrubber solution color change, and failure } \\
\text { to stop operation, scrubber tank } \\
\text { geometrically favorable }\end{array}$ & $\mathrm{k}_{\mathrm{efr}}=0.88$ (Note 1$)$ \\
\hline Seismic & Geometry & $\begin{array}{l}\text { Earthquake that would cause all fissile } \\
\text { material to accumulate at one corner of } \\
\text { glovebox is unlikely }\end{array}$ & $\mathrm{k}_{\text {eff }}=0.914$ (Note 3$)$ \\
\hline Fire & $\begin{array}{l}\text { Moderation } \\
\text { Reflection }\end{array}$ & $\begin{array}{l}\text { Melt glovebox panels; skirting prevents } \\
\text { sprinklers from dampening calciner } \\
\text { insulation; covers on polyjars limits water }\end{array}$ & $\mathrm{k}_{\mathrm{eff}}=0.912$ (Note 4$)$ \\
\hline $\begin{array}{l}\text { Plutonium oxide } \\
\text { density exceeded }\end{array}$ & Density & $\begin{array}{l}\text { Periodic density measurements, slow } \\
\text { increase in density per unit time }\end{array}$ & $\mathrm{k}_{\mathrm{eff}}=0.934($ Note 5$)$ \\
\hline $\begin{array}{l}\text { Second } 4 \mathrm{~L} \text { bottle of } \\
\text { acid in glovebox }\end{array}$ & Reflection & Operator training; operations procedures & $\mathrm{k}_{\mathrm{eff}}=0.88($ Note 1$)$ \\
\hline Significant spill of & Geometry & Operator training; operations procedures & $\mathrm{k}_{\mathrm{eff}}=0.87$ (Note 6$)$ \\
\hline $\begin{array}{l}\text { Plutonium-bearing } \\
\text { drum brought into } \\
\text { room } 188\end{array}$ & $\begin{array}{l}\text { Interaction } \\
\text { [plus Mass and } \\
\text { Volume] }\end{array}$ & Operator training; operations procedures & $\mathrm{k}_{\text {eff }}=0.88$ (Note 7$)$ \\
\hline $\begin{array}{l}\text { Dissolving plutonium } \\
\text { oxide in calciner }\end{array}$ & $\begin{array}{l}\text { Moderation } \\
\text { Geometry }\end{array}$ & $\begin{array}{l}\text { Incredible contingency: Two independent } \\
\text { errors of operator training and procedures }\end{array}$ & Calciner subcritical (Note 8) \\
\hline
\end{tabular}

Note 1: Section 5.2, MCNP case inpgc Note 2: Section 5.2, MCNP case inpge Note 3: Section 5.3.6, MCNP case pu_sph1.inp Note 4: Section 5.3.7
Note 5: Section 5.2, MCNP case inpgd

Note 6: Section 5.3.3

Note 7: Section 5.2, MCNP cases inpgc3p and inpgc3p450

Note 8: Section 5.3.12 


\subsection{SUMMARY}

The analysis in this CSER has shown that operations of the calciner with nitric acid feed meets the requirements of HNF-PRO-334, CRITICALITY SAFETY: GENERAL REQUIREMENTS (FDH 1997a). The analysis of normal conditions, normal plus expected abnormal conditions, and contingencies are within allowables. These results also indicated that only extraordinary changes to the present configuration can make a critical configuration. The plutonium would have to be removed from the calciner, dissolved or energetically mixed with water to a lower density than presently expected for calcine, reflected by several inches of water, and confined to a spherical shape to reach criticality. Even the seismic analysis in Section 5.3.6 does not predict that these conditions would be met. As summarized in the double contingency documentation (DCD) forms, the following contingencies are within allowables: adding plutonium feed solution; dissolving the plutonium in the calciner; dropping the calcine out of the calciner onto the product tray, even if saturated with plutonium solution; increasing the calcine density; bringing in bottles of plutonium solution. These results show that the calciner operations for acid feed are double contingent. Normal operation of the calciner containing $4.5 \mathrm{~kg}$ of plutonium oxide for the nitric acid feed testing has been found to have large margins of safety and no credible event or casual operator action would result in a criticality.

\subsection{SYSTEM DESCRIPTION AND NORMAL OPERATIONS}

\subsection{DENITRATION CALCINER SYSTEM DESCRIPTION}

The denitrating calcination system resides in the old 34-1 glovebox at the Plutonium Finishing Plant (PFP), which has been renamed 188-1. The process begins when a $4 \mathrm{~L}(4.2 \ell)$ nominal polybottle of solution is loaded into the glovebox. The nitric acid solution is then poured into the feed tank. A diaphragm pump slowly injects the solution from the feed tank into the hot calcine bed from below. The nitric acid produces no new calcine. The calciner outlet is closed to prevent loss of the calcine out of the calciner. The off-gases (water vapor, nitrogen oxides, and air injected into the calciner) are drawn through filters to the scrubber tank. In the scrubber tank, which operates at a negative pressure, the gases bubble through a chilled basic solution. The chilled solution condenses water vapor and removes nitrogen oxides from the off-gases. The scrubbed gases pass through the building vacuum system. The overflow from the scrubber flows to one of the catch tanks, from which the spent scrub solution is transferred out of the glovebox after testing for plutonium content and dispositioned based on the results. For acid test operations, only nitric acid will be added to this system. CSER 95-005 analyzed previous calciner operation and evaluates much more plutonium than will be present for the nitric acid run. Because these previous analyses are referenced, Section 2 describes the calciner system with the much more conservative CSER 95-005 analyzed system.

\subsubsection{Concentration and Composition of the Fissile Material}

${ }^{240} \mathrm{Pu}$ is less reactive than ${ }^{239} \mathrm{Pu}$, whereas ${ }^{241} \mathrm{Pu}$ is more reactive. In the base case analysis using MONK, the plutonium is considered to contain $3 \%{ }^{240} \mathrm{Pu}$ and approximately $1 \%{ }^{241} \mathrm{Pu}$ by weight of plutonium. Because some of the cases (Geiger 1995b) referenced in the CSER used $3 \%{ }^{240} \mathrm{Pu}$ and 
$0.6 \%{ }^{241} \mathrm{Pu}$, a minimum ${ }^{240} \mathrm{Pu}$ content of $3 \mathrm{wt} \%$, and a maximum ${ }^{241} \mathrm{Pu}$ content of $1 / 5{ }^{240} \mathrm{Pu} w \mathrm{wt} \%$ is specified as a limit on the $\mathrm{Pu}$ in the calciner for acid feed operation. The plutonium isotopic composition already present in the calciner has a ${ }^{241} \mathrm{Pu}$ content of $\sim 0.5 \%$.

2.1.1.1 Feed Solution. For the operations being allowed in this analysis, the feed solution is nitric acid. However, for the purposes of consistency with past analysis, the solution in the feed tank is often plutonium nitrate solution. While not expected to be the normal operation, the use of plutonium nitrate in place of a nitric acid is conservative from a criticality safety standpoint. Furthermore, this assumption helps to defend against the credible abnormal upset condition of mistakenly adding a plutonium nitrate solution instead of a plain nitric acid solution.

Feed solution at PFP may vary in plutonium concentration up to the allowable fissile concentration of $450 \mathrm{~g}$ Pu/ $/ \mathrm{in}$ PFP and PUREX solution processes (Hillesland 1997). Solubility problems are encountered above $450 \mathrm{~g} / \ell$ of plutonium nitrate and at less than $1 \mathrm{M}$ nitric acid. The specifications for the $P R$ solutions call for a maximum of $450 \mathrm{~g} / \ell$ plutonium nitrate and a minimum nitric acid concentration of $1 \underline{\mathrm{M}}$. At $450 \mathrm{~g} \mathrm{Pu} / \mathrm{l}$, the density of plutonium nitrate solution is $1.75 \mathrm{~g} / \mathrm{cm}^{3}$, based on theoretical density of $5.629 \mathrm{~g} / \mathrm{cm}^{3}$ for plutonium nitrate.

2.1.1.2 Calcine $\left(\mathrm{PuO}_{2}\right)$ Product. The maximum expected tap density of the calcine product is $5.0 \mathrm{~g} \mathrm{Pu} / \mathrm{cm}^{3}$, or $5.67 \mathrm{~g} \mathrm{PuO}_{2} / \mathrm{cm}^{3}$ for the oxide under normal operating conditions. This is based on experience with the PFP laboratory calciner, where normal product tap density was found to be 4.0 to $4.3 \mathrm{~g} \mathrm{Pu} / \mathrm{cm}^{3}$. A product density of $4.75 \mathrm{~g} \mathrm{Pu} / \mathrm{cm}^{3}$ was reached when it was continuously heated and stirred without addition of fresh feed solution (Nirider 1997).

Calcine product densities of $5.0,5.5,6.0$ and $6.5 \mathrm{Pu} / \mathrm{cm}^{3}$ were used for conservative evaluation of the calciner. However, operation of the calciner above $5.5 \mathrm{~g} \mathrm{Pu} / \mathrm{cm}^{3}\left(6.24 \mathrm{~g} \mathrm{PuO} / \mathrm{cm}^{3}\right.$ oxide) is not expected and is not justified by this CSER. The maximum theoretical calciner density possible is expected (Compton 1999b) to be $5.56 \mathrm{~g} \mathrm{Pu} / \mathrm{cm}^{3}\left(6.30 \mathrm{~g} \mathrm{PuO}_{2} / \mathrm{cm}^{3}\right)$.

2.1.1.3 Precipitated Pu Solids in Scrubber Tank. Precipitation of plutonium solids from nitrate solution which could pass through the intact calciner filters is modeled as plutonium nitrate at $2 \mathrm{~g} \mathrm{Pu} / \mathrm{cm}^{3}$ mixed with water in the scrubber tank. This gives a total density of $4.35 \mathrm{~g} / \mathrm{cm}^{3}$ based on a theoretical density of $5.629 \mathrm{~g} / \mathrm{cm}^{3}$ for plutonium nitrate, filling the remaining interstitial volume with water. The $2 \mathrm{~g} \mathrm{Pu} / \mathrm{cm}^{3}$ is considered a reasonable value. In general, the densest precipitate is plutonium oxide (Miller 1997). Plutonium oxide formed from plutonium nitrate at temperatures below $400^{\circ} \mathrm{C}$ has a bulk density of no more than $2 \mathrm{~g} \mathrm{PuO}_{2} / \mathrm{cm}^{3}$ according to page III.C.2-2 of ARH-600 (Carter 1968).

With $450 \mathrm{~g} \mathrm{Pu} / \ell$ solution in the scrubber tank, the $10 \mathrm{lnominal}$ volume holds $4.5 \mathrm{~kg}$ of plutonium. The plutonium mass for $2 \mathrm{~g} \mathrm{Pu} / \mathrm{cm}^{3}$ at the allowable $25.4 \mathrm{~cm}$ (10 in.) height of precipitate amounts to a total mass of $9.8 \mathrm{~kg}$ in each tank. Therefore, the density for the precipitate together with the allowable height is considered conservative.

2.1.1.4 Mud. Earthquake and fire scenarios may cause water flooding. Feed solution could be injected into a cold calciner (not credible for the nitric acid run). Each of these events allows for the formation of "mud" by mixing the liquid with the $\mathrm{PuO}_{2}$ product. In this section, it will be shown, 
using MONK6B results from Table 1 in CSER 97-004 (Hillsland 1997) presented in Table 3, that complete saturation of maximum density plutonium oxide with maximum concentration feed solution yields the most reactive mud composition.

\begin{tabular}{|c|c|c|c|c|c|c|c|}
\hline \multicolumn{8}{|c|}{$\begin{array}{l}\text { Table } 3 \text {. Reactivity for Various Forms of "Mud" } \\
\text { Results in this table used } 5 \%{ }^{240} \mathrm{Pu} \text { and } 2 \%{ }^{24 t} \mathrm{Pu} \text { in plutonium }\end{array}$} \\
\hline Case & $\begin{array}{l}\text { Product } \\
\text { Density } \\
\left(\mathrm{g} \mathrm{Pu} / \mathrm{cm}^{3}\right)\end{array}$ & $\begin{array}{l}\text { Total } \mathrm{Pu} \\
\text { Density } \\
\left(\mathrm{g} \mathrm{Pu} / \mathrm{cm}^{3}\right)\end{array}$ & Liquid & $\begin{array}{l}\text { Percent } \\
\text { Saturation }\end{array}$ & $\mathrm{H} / \mathrm{Pu}$ & $k_{\text {eff }}$ & $\begin{array}{l}\text { Std. } \\
\text { Dev. }\end{array}$ \\
\hline solsp50 & 5.00 & 5.23 & Pu solution ${ }^{(1)}$ & $100 \%$ & 2.51 & 0.9438 & 0.0029 \\
\hline sol55n & 5.50 & 5.71 & Pu nitrate ${ }^{(2)}$ & $100 \%$ & 1.78 & 0.9443 & 0.0029 \\
\hline solsp 55 & 5.50 & 5.71 & $\mathrm{Pu}_{\text {solution }}{ }^{(1)}$ & $100 \%$ & 2.07 & 0.9650 & 0.0029 \\
\hline solsp & 6.00 & 6.18 & Pu solution ${ }^{(1)}$ & $100 \%$ & 1.71 & 0.9807 & 0.0029 \\
\hline HPU $50 \mathrm{~s}$ & 6.00 & 6.09 & Pu solution ${ }^{(1)}$ & $44 \%$ & 0.85 & 0.9354 & 0.0029 \\
\hline HPu25s & 6.00 & 6.05 & Pu solution ${ }^{(1)}$ & $22 \%$ & 0.43 & 0.9243 & 0.0029 \\
\hline HPUO & 6.00 & 6.00 & (none) & $0 \%$ & 0.00 & 0.8997 & 0.0029 \\
\hline HPu $50 w$ & 6.00 & 6.00 & Water & $49 \%$ & 0.88 & 0.9254 & 0.0029 \\
\hline HPulOOw & 6.00 & 6.00 & Water & $100 \%$ & 1.80 & 0.9673 & 0.0029 \\
\hline HPu450w & 4.00 & 4.00 & Water & $100 \%$ & 4.01 & 0.9027 & 0.0029 \\
\hline HPul200w & 2.00 & 2.00 & Water & $100 \%$ & 10.6 & 0.8486 & 0.0029 \\
\hline
\end{tabular}

I $450 \mathrm{~g} \mathrm{Pu} / \mathrm{l}$ plutonium water mixture in interstitial space

$2450 \mathrm{~g} \mathrm{Pu} / \ell$ plutonium nitrate solution

The theoretical density of plutonium oxide is $11.46 \mathrm{~g} / \mathrm{cm}^{3}$ (Carter 1968). Given an assumed product density, one may calculate the interstitial volume available for liquid saturation. For example, an assumed product density of $6.0 \mathrm{~g} \mathrm{Pu} / \mathrm{cm}^{3}$ corresponds to a total $\mathrm{PuO}_{2}$ product density of $6.80 \mathrm{~g} / \mathrm{cm}^{3}$. Comparison of this density to the theoretical density for $\mathrm{PuO}_{2}$ indicates a void fraction of 0.406 in the product. Filling this void space with liquid would be considered full saturation.

The cases listed in Table 3 were modeled (Hillesland 1997) with the calciner full of mud, the calciner filters filled with $450 \mathrm{~g} \mathrm{Pu} / \ell$ feed solution and the calciner lower insulation saturated with water. The floor is covered with $0.953 \mathrm{~cm} \mathrm{(3/8} \mathrm{in.)} \mathrm{of} \mathrm{the} \mathrm{same} \mathrm{mud} \mathrm{as} \mathrm{in} \mathrm{the} \mathrm{calciner,} \mathrm{and} \mathrm{above} \mathrm{it,}$ $4.45 \mathrm{~cm}$ (1-3/4 in.) of $450 \mathrm{~g}$ Pu/l feed solution, which reaches to the top of the criticality drain. The scrubber tank and two feed tanks are modeled with $25.4 \mathrm{~cm}$ (10 in.) of Pu particulates, and then are filled to the top with $140 \mathrm{~g} \mathrm{Pu} / \ell$ feed solution. The product receiver vessels are filled with the same mud as in the calciner, two are under the calciner and two $25.4 \mathrm{~cm}(10 \mathrm{in}$.) away towards the scrubber tank. The calciner mud was made of various density calcine, $450 \mathrm{~g}$ Pu/l feed solution or water, and at different saturations to vary the $\mathrm{H} / \mathrm{Pu}$ to find the most reactive mud. For the dry case, the calciner and product receiver containers hold dry product and the filters are full, but the tanks are as described above and the mud on the floor is saturated with $450 \mathrm{~g}$ Pu/ $\ell$ solution. As internal flooding of the calciner is considered an independent event from flooding external to the calciner, these cases represent 
higher $\mathrm{H} / \mathrm{Pu}$ ratios, it is necessary to reduce the plutonium oxide density because of the limited volume in the calciner.

Most cases were run for plutonium solution (plutonium and water only), excluding the nitrate in feed solution. This is conservative in comparison to an equivalent case using plutonium nitrate, and allows for easier comparison to the cases involving water saturation. Case sol55n shows that the reactivity drops over 0.020 in $\mathrm{k}_{\text {eff }}$ when nitrate is included at a total plutonium density of $5.71 \mathrm{~g} \mathrm{Pu} / \mathrm{cm}^{3}$.

Table 3 indicates that for product densities up to $6.0 \mathrm{~g} \mathrm{Pu} / \mathrm{cm}^{3}$, the most reactive mud is formed with the highest density $\mathrm{PuO}_{2}$ fully saturated with $450 \mathrm{~g} \mathrm{Pu} / \mathrm{l}$ solution, forming the material with the highest plutonium density.

2.1.1.5 4L Bottle. Nitric acid solutions are expected to be handled in $4 \mathrm{~L}$ bottles. The $4 \mathrm{~L}$ bottle is made of low-density polyethylene and has a capacity of $4.2 \ell$, with a wall thickness of approximately $0.16 \mathrm{~cm}(0.063 \mathrm{in}$.). The inside diameter is $11 \mathrm{~cm}(4.33 \mathrm{in}$.), and the outside height is assumed to be $24.33 \mathrm{~cm}(9.58 \mathrm{in}$.).

\subsubsection{Glovebox}

Glovebox $188-1$ at PFP is described in drawings H-2-3712, $\mathrm{H}-2-28536, \mathrm{H}-2-28584$, $\mathrm{H}-2-33764$. The main section of the glovebox measures $244 \mathrm{~cm}(8 \mathrm{ft})$ long by $112 \mathrm{~cm}(3 \mathrm{ft}-8 \mathrm{in}$.) wide by $211 \mathrm{~cm}(6 \mathrm{ft}-11 \mathrm{in}$.) high. At one end, there are two narrower sections $91 \mathrm{~cm}(3 \mathrm{ft})$ wide by $94 \mathrm{~cm}$ ( $3 \mathrm{ft}-1 \mathrm{in}$.) long. The upper narrower section (attic) is $84 \mathrm{~cm}$ ( $2 \mathrm{ft}-9 \mathrm{in}$.) tall with a ceiling continuous with the main box. The lower narrow section (annex of the basement) is $91 \mathrm{~cm}(3 \mathrm{ft}$ ) tall, with a floor continuous with the floor of the main box. There is an intermediate floor in the main section, $152 \mathrm{~cm}$ $(5 \mathrm{ft})$ below the ceiling. This leaves approximately $58 \mathrm{~cm}(1 \mathrm{ft}-11 \mathrm{in}$.) below the intermediate (main) floor that the calciner rests upon. The downcomer empties into the product receiver, which is below the intermediate floor of the calciner section, but suspended above a tray that is also above the bottom floor of the calciner section. A sketch of the glovebox is given in Figure 1. 
Figure 1. Prototype Calciner Glovebox 188-1.
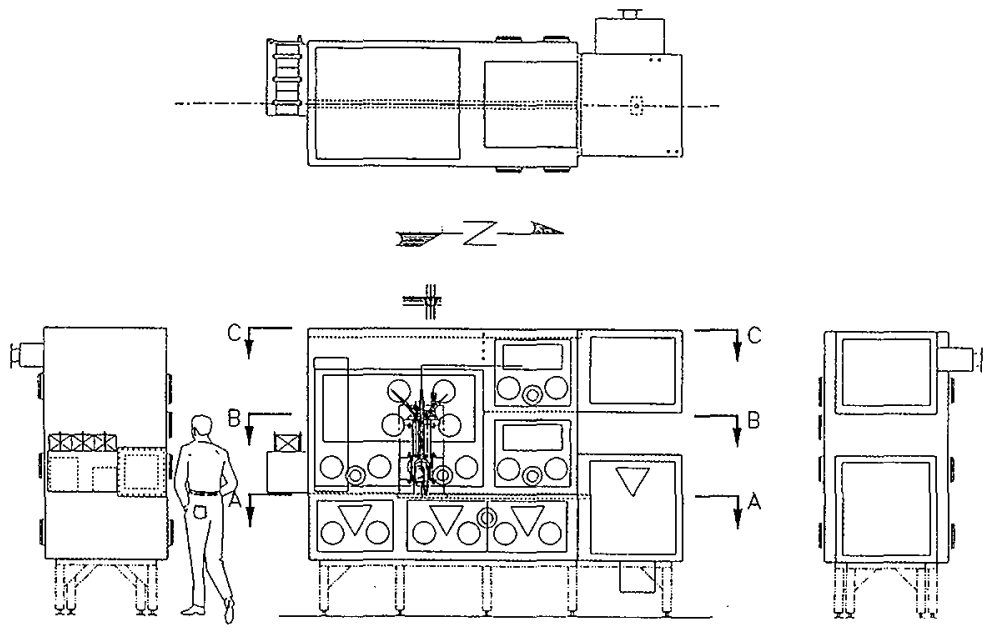

2.1.2.1 Criticality Drain. To protect against spills, the glovebox contains a bottom-mounted criticality drain, described in $\mathrm{H}-2-28536$, as changed by ECN-125369 and ECN-185589. This $7.62 \mathrm{~cm}$ (3 in.) diameter drain projects $5.08 \mathrm{~cm}$ (2 in.) into the glovebox. The criticality drain is located underneath the scrubber in the basement. The criticality drain limits the flooding of the glovebox to a static depth of $5.08 \mathrm{~cm}(2 \mathrm{in}$.).

2.1.2.2 Accumulation of Fissile Material on Glovebox Floor. The present (27 January 1999) plutonium inventory assigned to glovebox holdup is up to $14 \mathrm{~g} \mathrm{Pu}$ (Hieb 1995). Previous analyses (Hess 1995, Geiger 1995a) assumed substantial thickness of fissile material on the glovebox floor. This analysis assumes that any spill will be cleaned up soon after the spill, so that there will be no noticeable accumulation of solid fissile material on the glovebox floor.

2.1.2.3 Water Flooding the Glovebox. There is water flowing through the scrubber system from a closed system in a neighboring room with a capacity of approximately $20 \ell(5 \mathrm{gal}$.). If this total inventory were flooded into the calciner section of the glovebox, the flooded thickness would be $0.559 \mathrm{~cm}(0.220 \mathrm{in}$.) water.

There is a limited volume water bottle extinguishing system for fires inside the glovebox, as well as a fire extinguishing spray outside the glovebox. The unlimited volume water supply would remain outside the glovebox as long as the glovebox maintains its structural integrity. If the fire extinguishing spray was turned on and some breach was created in the glovebox to let water in, but not out, then the liquid depth would be limited to a $5.7 \mathrm{~cm}$ ( $2.2 \mathrm{in}$.) depth due to the criticality drain as determined in Section 5.3.8 in this CSER. 
HNF-3908 Rev. 0

\subsubsection{Vertical Calciner}

The calciner is depicted in several drawings (H-2-95609). Due to the high temperatures employed in the calcination process and the presence of nitrates and nitrogen oxides in the off-gases, the structure of the calciner is made of 310 stainless steel. The calciner consists of two functional units, bolted together to form a continuous void space. The lower calcining section should normally be the only part of the calciner with any significant quantity of calcine in it. The upper filtration section houses the off-gas filters. A stirring assembly (agitator blade in Figure 2) in the lower calcining section is driven via a steel shaft, which passes through the centerline of the upper filtration section. Figure 2 illustrates the conceptual design of the calciner. The calciner is mounted on the intermediate (main) floor of the glovebox (noted as bottom plate in Figure 2) at a distance of no less than $40.64 \mathrm{~cm}$ (16 in.) from both the feed tank and the scrubber. The downcomer penetrates the intermediate (main) floor into the lower (basement) section of the glovebox.

2.1.3.1 The Lower Section. Calcination is accomplished in an annulus between the inner and outer walls of the lower calcining section. The outer wall is a $22.86 \mathrm{~cm}$ (9 in.) long section of $6 \mathrm{in}$. Schedule 10 pipe made of 310 stainless steel, with flanges on each end. The inner wall is a 4 in. Schedule 10,310 stainless steel pipe with a pipe cap on the top. A stirrer, made of a section of pipe welded to a pipe cap and with several pieces cut out to produce long prongs, agitates the calcine. The top of the stirrer is welded to a power shaft that extends through the upper filtration section.

The lower section of the calciner is wrapped in insulation. The outer wall is surrounded by a heating element cast in porous insulation. The insulation has an inside diameter of $20 \mathrm{~cm}(7-7 / 8 \mathrm{in}$.$) ,$ an outside diameter of $39.7 \mathrm{~cm}$ (15-5/8 in.), and a height of $20.2 \mathrm{~cm}$ ( $8 \mathrm{in}$.$) . As described in$ Appendix E of CSER 95-005 (Geiger 1995a), the insulation is easily saturable with water. To protect the insulation from falling water, a metal skirt covers the lower insulation. It begins inside the upper "mirror" insulation and extends below the insulation to form a drip end to prevent wicking up into the insulation. Falling water would not get into the insulation. However, because it can not be confirmed that the insulation is dry, analyses model this insulation as saturated with water.

Inside the inner annulus wall are a heating element and a calcine overflow downcomer. The downcomer is made of $1 \mathrm{in}$. schedule 10,310 stainless steel pipe. The top of the downcomer is capped with a piece of 310 stainless steel plate. Where the downcomer parallels the inner annulus wall, the downcomer is sliced and bent open to form straight rectangular walls, separated to the dimension of the inside diameter of the pipe. The straight walls are welded to a same-sized rectangular opening in the inner annulus wall. The downcomer protrudes through the bottom of the calciner. A 1 in. tube, attached to the product receiver, fits into the downcomer and sets the overflow level for the calciner. By raising or lowering the overflow tube inside the downcomer, the overflow level is changed by the level of the overflow tube top. This is how the calcine upper bed level is controlled. 
HNF-3908 Rev. 0

Figure 2. Vertical Calciner

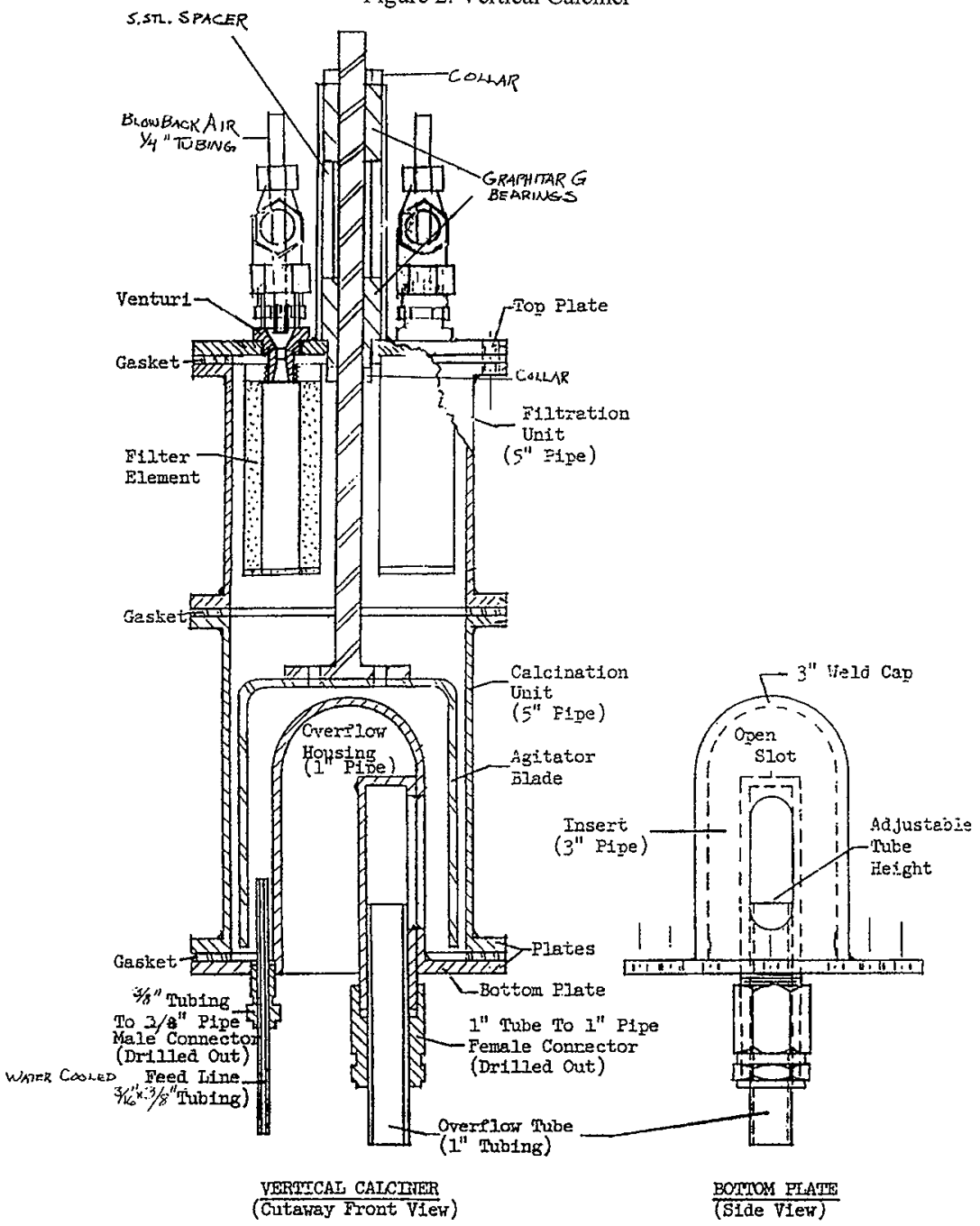


2.1.3.2 The Upper Section. The upper filtration section is a 6-inch schedule 10 pipe made of 310 stainless and surrounded with non-water absorbing insulation. A $2.54 \mathrm{~cm}$ (1 in.) diameter shaft passes down the centerline of this section to drive the stirrer in the lower section. The pipe is $30.48 \mathrm{~cm}$ (12 in.) long, with flanges on each end. Two plates are above the upper flange, the upper plate is $2.54 \mathrm{~cm}(1 \mathrm{in}$.) thick, while the lower is $5.08 \mathrm{~cm}(2 \mathrm{in}$.) thick and holds the three silicon carbide filters, which extend the length of the filtration section. In place of a fourth filter is a covered pressure relief opening for the filtration section. A beveled weight sits above the opening and will lift up to relieve pressure at 1.3 psig. The filters are back-pulsed by a preset timer to clear them of dust.

This section is wrapped in 304 stainless steel reflective "mirror" insulation that does not absorb liquids (see Appendix B of Geiger 1995b). The bulk of the insulation consists of concentric cylinders of foil, separated by thin strips of foil. The "mirror" insulation is made of two concentric right circular cylinders with the inner cylinder directly attached to the outer. The cylinders are made in semicircular halves to allow assembly and disassembly on the calciner. The outer cylinder has a 40 -cm outside diameter and 25.4-cm inside diameter, which is also the OD of the inner cylinder. The inner cylinder's ID is $19.7 \mathrm{~cm}$. The outer cylinder is $37.1 \mathrm{~cm}$ tall. The inner cylinder is $21.6 \mathrm{~cm}$ tall and attached with its top $10.8 \mathrm{~cm}$ beneath the top of the outer cylinder. The total volume of the insulation is $32.2 \mathrm{l}$ with $27.8 \ell$ of that volume in the outer cylinder. The unit has a mass of approximately $10 \mathrm{~kg}(22 \mathrm{lb})$, and an average density of $0.32 \mathrm{~g} / \mathrm{cm}^{3}$.

The inner and outer cylinders are subdivided internally into 15 concentric chambers separated by sheet metal. Eleven of those chambers are in the outer cylinder. Additional narrow sheet metal sections are formed into numerous zig-zig-shaped lengths that extend from the top to the bottom of each internal chamber. These narrow strips of metal create a "honeycomb" effect in each chamber, creating many spaces of dead air to decrease heat transfer through this all-metal insulation.

Appendix B of the Addendum to CSER 95-005 (Geiger 1995b) contains a test showing the "mirror" insulation, used in the upper section of the calciner, drains at a rate of $25 \mathrm{l} /$ minute. This indicates that a fill rate of at least $25 \mathrm{\ell}$ minute is required to cause accumulation of liquid in the insulation. Consequently, to fill the insulation on the upper section with water is considered incredible.

2.1.3.3 Product Collection Tube. A product collection tube (over flow to be on Figure 2) is used to feed the final product from the calciner into product receiver vessel. The top of the tube is inside the center dome of the calciner. There is a $11.43 \mathrm{~cm}(4.5 \mathrm{in}$.$) tall slot in the side of the dome to$ allow product to flow from the calciner down the tube into an attached product receiver vessel. The top of the tube forms a weir to control the height of the product inside the calciner. A valve attached to the product collection tube controls the flow of product. The tube was found to adjust such that the bottom may range between $12.7 \mathrm{~cm}(5 \mathrm{in}$.) to $30.48 \mathrm{~cm}$ (12 in.) from the glovebox floor.

2.1.3.4 Internal Flooding. Flooding can be caused by many scenarios such as: feeding a nitric acid solution into a cold calciner; feeding a nitric acid solution into the calciner too quickly; or pouring the nitric acid into the calciner through a relief port. 


\subsubsection{Feed System}

2.1.4.1 Feed Polybottle. The feed is contained in the $4 \mathrm{~L}$ polybottles. Lab measurements (Compton 1999e) show that the actual volume for a nominal 4L narrow mouth polybottle is $4.2 \mathrm{l}$. The polybottle has an outer diameter of $15.2 \mathrm{~cm}(6.0 \mathrm{in}$.) and an effective height of $26.7 \mathrm{~cm}(10.5 \mathrm{in}$.) up to the bottom to the outlet neck. The inside dimension of the polybottle is expressed as $425 \mathrm{~g}$ of water per inch of height (Hess 1994). The tare mass of the polybottle is given as $420 \mathrm{~g}$ low density polyethylene. The feed polybottle size allows it to be moved around the glovebox.

2.1.4.2 Feed Tank. The feed tank is depicted in drawing SK-2-300307. The feed tank is made from a $30.48 \mathrm{~cm}$ (12 in.) section of 6 in. borosilicate glass pipe (inside radius of $7.856 \mathrm{~cm}$, wall thickness of $0.502 \mathrm{~cm}$ ). The top of the tank is open. The contained volume of the feed tank is modeled as $5.9 \ell$. The feed tank is mounted on the intermediate (main) floor of the glovebox, at a distance of at least $40.64 \mathrm{~cm}$ (16 in.) from both the calciner and the scrubber. The measured feed tank inside diameter was $14.92 \mathrm{~cm}(5.88 \mathrm{in}$.) and the volume was determined to be $5.2 \mathrm{l}$, which is less than the modeled 5.9 l. Spilling the feed tank contents on the glovebox floor, calculates to a $0.145 \mathrm{~cm}$ (0.057 in.) possible depth of the liquid.

2.1.4.3 The Diaphragm Feed Pump. The solution is fed from the feed tank into the calciner by a Milton Roy Liquid Metronics Division series $\mathrm{C}$ electronic metering pump. According to the drawings in the catalogue, the liquid end has a diameter of $14.63 \mathrm{~cm}(5.76 \mathrm{in}$.) and a thickness of $5.3 \mathrm{~cm}(2.1 \mathrm{in}$.). The feed pump is located on the bottom floor of the glovebox.

\subsubsection{Scrubber System}

The scrubber scrubs the acid vapors out of the calciner off-gas. The calciner off-gas is acidic (from the $\mathrm{HNO}_{3}$ and $\mathrm{NO}_{\mathrm{x}}$ vapors that may react with $\mathrm{H}_{2} \mathrm{O}$ ) and the scrub solution is caustic. The heated calciner off-gas is also cooled in the scrubber. The spent scrubber solution is drained from the scrubber to the spent scrubber solution catch (or receipt) tanks.

The scrubber system is composed of:

- The scrubber, a 6 inch diameter, $117.76 \mathrm{~cm}$ (46-5/8 in.) high borosilicate pipe used as approximately a $20 \ell$ tank,

- The scrub solution catch tanks, two 6 inch nominal diameter, 22 l tanks receiving spent scrub solution,

- A chilled water supply with a 19 e (5-gal) capacity,

- A vacuum trap that connects to the plant process vacuum system, and

- A scrub solution reservoir and scrub solution pump

2.1.5.1 Scrubber Tank. The off-gas scrubber is a vertical section of 6-inch diameter Pyrex ${ }^{1 T M}$ glass pipe (SK-2-300306), filled with an alkaline scrub solution. The scrub solution is cooled by a $91.44 \mathrm{~cm}$ ( $36 \mathrm{in}$.) tall cooling coil of $1.27 \mathrm{~cm}(1 / 2$ in.) diameter 304 stainless steel tubing with a $.089 \mathrm{~cm}$

${ }^{1}$ Pyrex is a trademark of Corning Glass works, Coming, N.Y. 
( 0.035 in.) wall. The inside diameter of the cooling coil is $9.84 \mathrm{~cm}(3-7 / 8 \mathrm{in}$ ); the outside, $12.38 \mathrm{~cm}$ (4-7/8 in.). The off-gas flows from the top of the scrubber through a pipe and a porous quartz glass (drawing SK-2-300306) plate into the scrub solution below the cooling coil. The gas bubbles entrain the scrub solution, flow up the inside of the cooling coil, and disengage at the top of the scrubber. The liquid flows down around the outside of the cooling coil. The scrubbed off-gas exits the top of the scrubber. A stand pipe of stainless steel tube (same specifications as the cooling coil) located between the cooling coil and the scrubber outer wall, protrudes $15.24 \mathrm{~cm}(6 \mathrm{in}$.) above the cooling coil and conducts scrub solution overflow out of the scrubber and into the scrub solution catch tanks. The scrubber is mounted on the intermediate floor, no less than $40.64 \mathrm{~cm}$ (16 in.) from both the calciner and the feed tank.

The silicon carbide filters in the calciner should prevent significant fissile contamination of the scrubber. Human observation provides manual system shutoff upon failure of a filter.

2.1.5.2 Spent Scrubber Receipt Tanks. Each scrub solution receipt tank is a $122 \mathrm{~cm}$ (4 ft) section of 6 in. borosilicate glass pipe. The axes of the two tanks are aligned along the long axis of the glovebox. These tanks are located on the bottom floor in the annex, with a minimum of $40.64 \mathrm{~cm}$ (16 in.) between their outer surfaces.

The scrub solution catch tanks accept and retain the spent scrub solution from the scrubber and give the non-condensible exhaust gases a path to the vacuum trap then to the plant process vacuum system. Periodically the scrub solution catch tanks are drained from Glovebox 188-1 into the building radioactive drain system after being sampled for plutonium content. These spent scrub solution catch tanks have also been referred to as "phase disengaging tanks" (Compton 1997). As phase disengaging tanks, they allow gases to exit from the top of these tanks through a vacuum trap (SK-2-300310) locared in the glovebox, and the liquids to collect at the bottom of the slightly sloped catch tanks. The plant 26 in. Hg process vacuum draws the air injected into the calciner through the filters, scrubber, scrub catch tanks, and vacuum trap.

2.1.5.3 Scrubber Chilled Water Supply. The scrubber tank is cooled by chilled water flowing through cooling coils in the scrubber tank. The cooling water comes from a $19 \ell$ (5-gal) reservoir that is located in an adjacent room, Room 187. The $19 l$ (5-gal) reservoir, a non-favorable geometry reservoir is analyzed in Section 5.3.5.3.

2.1.5.4 Spent Scrub Solution Vacuum Trap. The two $22 l$ spent scrubber solution storage tanks are connected through a vacuum trap to the PFP $234-5 \mathrm{Z}$ plant 26 in. $\mathrm{Hg}$ process vacuum system. The vacuum trap in Glovebox 188-1 that is on the flow path between the spent scrubber solution storage tanks and the 234-5Z process vacuum system is (per drawing SK-2-300310, sheets 1 and 2) a 6 in. length of nominal 3 in. diameter Pyrex ${ }^{\mathrm{TM}}$ glass pipe. A polyethylene ball floats up against the trap's outlet if liquid fills the trap. If the ball floats up to the trap outlet, the sealing action ends the vacuum to the off-gas system, and, in turn, ends off-gas flow through the system. When the off-gases stop flowing through the scrubber, its liquid level drops, ending the flow of liquid to the disengaging tank in use (Compton 1997). The vacuum trap is redundant to the demisters built into the plant 26 in. $\mathrm{Hg}$ process vacuum system which also shuts off the gas flow to the plant vacuum system.

2.1.5.5 Scrubber Solution Supply. A scrubber solution reservoir and scrubber solution pump form the scrubber solution supply system (Compton 1997). The caustic solution enters the scrubber at 
the top, but is discharged 15 in. below the entry point on the inside of the cooling coils, where the rising calciner off-gas bubbles are mixing with the scrubber solution.

Room 188 contains a $55-$ Gallon drum of 30 weight percent $(10 \mathrm{M})$ sodium hydroxide that is pumped into Glovebox 188-1 for fresh scrubbing solution in the scrubber (Compton 1997). A positive displacement pump reduces the possibility of back flow from the scrubber to the caustic solution reservoir pump. There is also a check valve in the line at the outlet to the pump as an additional means to prevent the highly unlikely backflow of scrubber solution back into the caustic supply drum. A ball valve also exists between the caustic drum pump and the scrubber that is normally closed, and must be opened to permit flow into the scrubber (Compton 1997).

\subsubsection{Containers}

2.1.6.1 The Product Receiver. The product receiver is an advertised $500 \mathrm{ml}$ nominal (1 pt) borosilicate glass reaction kettle with a rounded bottom. The product receiver volume was measured to be $850 \mathrm{ml}$. The inside height is $15.24 \mathrm{~cm}$ (6.0 in.), and the inside diameter is $8.89 \mathrm{~cm}(3.5 \mathrm{in}$.), which gives a volume of $945 \mathrm{ml}$ for a flat bottomed cylinder. The glass walls are about $0.476 \mathrm{~cm}$ (3/16 in.) thick. The bottom is more rounded on the sides than a standard beaker, but is flat in the middle. The product receiver is removable from the calciner downcomer to allow emptying into the load out container.

2.1.6.2 The Load out Container. The load out container for this system is part number 42-1500-300, commonly known as a "1 pound can." The $1 \mathrm{lb}$ slip lid can has a nominal capacity of $0.5 \ell$ and an actual volume of $0.55 \ell$. A pan located under the calciner includes storage spots for two of these containers to keep their normal spacing at no less than $40.64 \mathrm{~cm}$ (16 in.). Each load out container can be moved to glovebox ports to exit the glovebox. A maximum of 2 cans are allowed in the basement, one on the main level and 2 in the attic.

2.1.6.3 Other Containers. There can be twenty $30 \mathrm{ml}$ sample vials of up to $0.6 \mathrm{l}$ volume, containers of lubricants of up to $750 \mathrm{ml}$ volume, and small measurement containers of up to $30 \mathrm{~m} \ell$ volume.

\subsection{NORMAL OPERATION DESCRIPTION}

The intended initial laboratory calciner operation is for operator training in the complex calciner operation, and to demonstrate hardware functioning. It is not intended to process or calcine new fissile material solutions into $\mathrm{PuO}_{2}$ or other fissile oxides.

The normal operation planned for the initial operation is that the $4.05 \mathrm{~kg} \mathrm{Pu}$ in the calciner will remain in place. Figure 3 demonstrates the normal calciner process flow schematic (Compton 1997, Stubbs 1997). The feed tank will be filled with $\mathrm{HNO}_{3}$ from $4 \mathrm{~L}$ polybottles that are transferred into the glovebox through the air lock. The calciner will be heated, and the feed $\mathrm{HNO}_{3}$ will be pumped into the calciner, the boiled off $\mathrm{HNO}_{3}$ off-gas and any other vapors will be neutralized and cooled in the scrubber. The scrubber overflow and escaping neutralized gases will proceed to the spent scrubber 
HNF-3908 Rev. 0

Figure 3. Calciner Process Flow Schematic

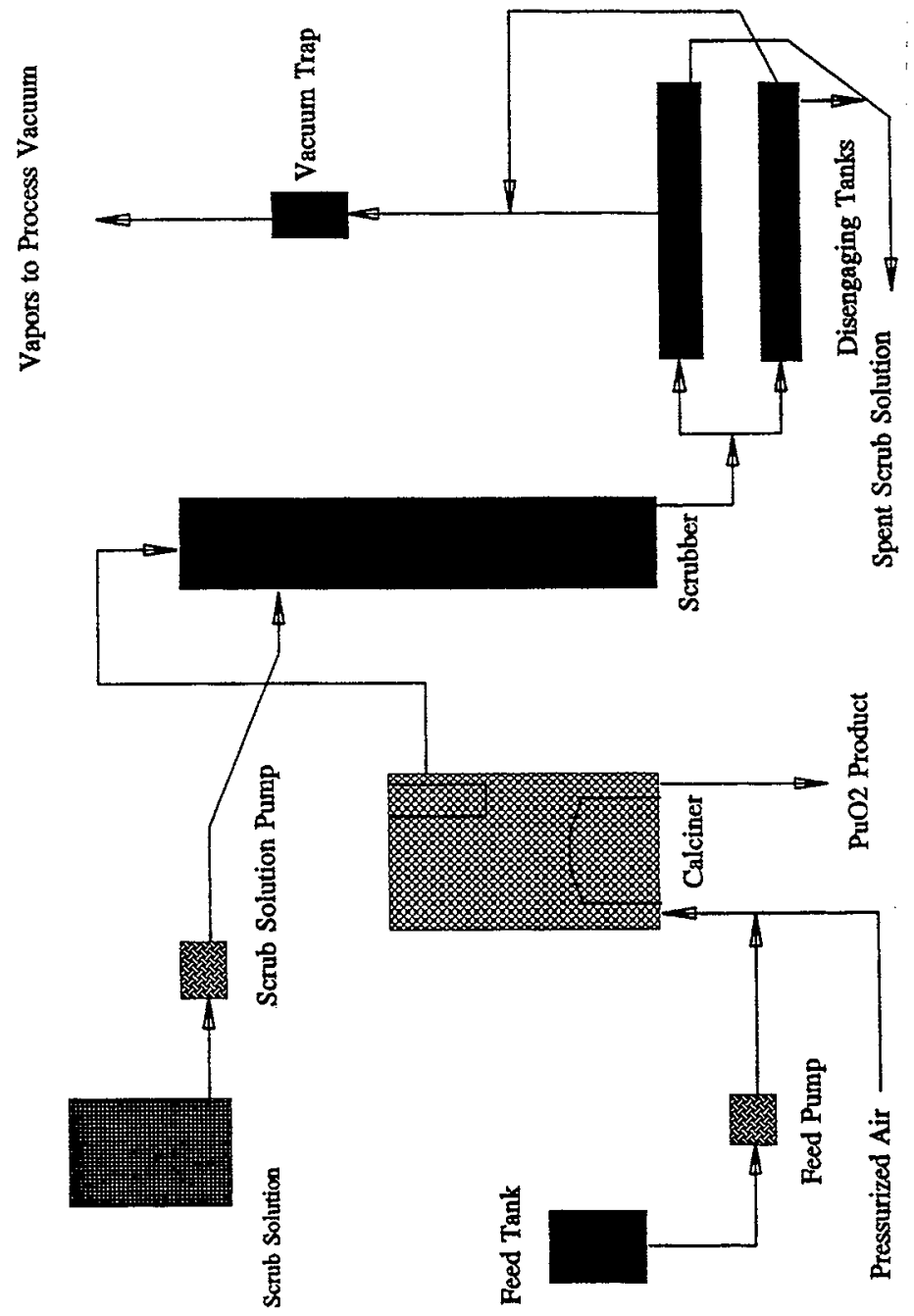


storage tanks, also called phase disengaging tanks, where the gas will exit the glovebox through the plant vacuum system, while the liquid will be transferred out in batches. The re-calcined $\mathrm{PuO}_{2}$ residing in the calciner may become denser, and some of it may be spilled into the product receiver but this is not expected because the receiver tube will be pushed up so as to confine the calcine to the calciner and prevent it overflowing into the product receiver. This $\mathrm{PuO}_{2}$ overflow from the calciner into the product receiver may be collected into a $0.5 \ell$ slip lid can that could be bagged out of the glovebox.

\subsection{LIMITS AND CONTROLS}

\subsection{LIMITS}

\subsubsection{Mass and Isotopies}

The total plutonium mass in the glovebox shall be limited to $4.5 \mathrm{~kg}$. The plutonium is to contain at least $3 \mathrm{wt} . \%{ }^{240} \mathrm{Pu}$, and a maximum ${ }^{241} \mathrm{Pu}$ content of one-fifth $(1 / 5)$ of the ${ }^{240} \mathrm{Pu}$. Uranium enriched to $1.25 \mathrm{wt} \%{ }^{235} \mathrm{U}$ may be processed in the calciner.

\subsubsection{Moderation}

Hydrogenous material except lubricants and feed solutions are prohibited from the interior of the calciner. Feed shall not be added to a cold calciner. The combined volume of all lubricants and their containers is limited to $0.75 \ell$.

\subsubsection{Volume and Process Equipment}

Volume is to be controlled by allowing only the following containers in the glovebox that have capacity to hold fissile material:

Process equipment: calciner, product receiver jar ( $0.85 \ell)$, feed tank (5.2 l), vacuum trap, and the vessels of the scrubber system. Containers: one polybottle of 4.2 liters maximum, four $0.5 \ell$ polyjars or slip lid containers, twenty $30 \mathrm{~m} \ell$ sample bottles or small measurement containers, and up to $750 \mathrm{~m} \ell$ of containers of maintenance fluids in the glovebox. Total allowed volumes of $0.5 \ell$ containers: $1.1 \ell$ in attic, $0.55 \ell$ on main floor, and $1.1 \ell$ in basement.

\subsubsection{Spacing}

a. Containers of fissile material shall be spaced a minimum of $25.4 \mathrm{~cm}$ (10 in.) from any other containers of fissile material.

b. Only one container may be within $25.4 \mathrm{~cm}$ (10 in.) of the calciner.

c. No spacing is required to transfer material from one container to another or to clean up a spill. 


\subsubsection{Wet Insulation}

Calciner operation is allowed only with dry calciner insulation. If the calciner insulation is known to be wet, stop or prohibit addition of feed to the calciner. If there are no spills on or splashes of liquids at or steam around the insulation, it may be considered dry.

\subsubsection{Plutonium Solutions or Plutonium Materials}

No additional fissionable materials or fissionable solutions shall be introduced into the calciner or the glovebox. Plutonium spilled or removed from the calciner may be put back into the calciner.

\subsubsection{Solids and Precipitates}

The depth of solids and precipitates in the scrubber tank in the glovebox is limited to a total height of $25.4 \mathrm{~cm}(10 \mathrm{in}$.). Any solids accumulation height in excess of $25.4 \mathrm{~cm}$ shall be removed from the tank in accordance with an approved written plan prior to continuing operations.

\subsubsection{Criticality Drain}

The $7.6 \mathrm{~cm}$ ( 3 in.) diameter criticality drain in the glovebox shall not be obstructed and shall be in operable condition.

\subsubsection{Floor Accumulations}

Any spill of fissile material shall be expeditiously cleaned up before further operations.

\subsubsection{Rags}

Clean-up rags are limited to up to $1 \mathrm{ft}^{2}$ area each and $6 \mathrm{ft}^{2}$ total in the glovebox at a time. Only one rag is allowed adjacent to a given piece of equipment or a given container with fissile material at a time.

\subsubsection{Use of Plastics}

Use of plastic bags, sleeves or sheets inside or outside of Glovebox 188-1 shall be approved by operating procedure, or approved work plan which conforms to the general limits as listed in PFP Criticality Prevention Specifications, CPS-165-80010.

containers or tissile material.

b. Only one container may be within $25.4 \mathrm{~cm}(10 \mathrm{in}$.) of the calciner.

c. No spacing is required to transfer material from one container to another or to clean up a spill. 
HNF-3908 Rev. 0

d. Containers may be placed on the glovebox decking, product tray, or shelves, but not on the calciner insulation horizontal surfaces.

e. Ten $30 \mathrm{ml}$ sample jars may be stored in a group spaced a minimum of $25.4 \mathrm{~cm}(10 \mathrm{in}$.) from other containers or fissile bearing objects.

f. No stacking containers.

g. One open or closed $30 \mathrm{ml}$ sample vial may be anywhere in the glovebox.

\subsubsection{Density}

Plutonium density shall be limited to $5.5 \mathrm{~g} \mathrm{Pu} / \mathrm{cm}^{3}$.

\subsubsection{Fluoride Compounds}

Fluoride compounds and similarly strong dissolving compounds are prohibited in the feed solution and the interior of the calciner. (Nitric acid is not a strong dissolver of plutonium.)

\subsubsection{Disassembly of calciner}

Additional limits for disassembly of the calciner:

a. The top plate and attached filters and piping shall be removed first.

b. Remove loose fissile material from above the junction of the upper and lower spool pieces before removing the upper spool piece.

c. If there is a spill of fissile material in the glovebox, discontinue disassembly operations until the spill has been cleaned up.

\subsection{PROCESS CONTROLS}

\subsubsection{Pu Density Limit}

The plutonium density limit of $5.5 \mathrm{~g} \mathrm{Pu} / \mathrm{cm}^{3}$ shall be met by frequent measurements of the calcine bulk density. If measurements approach a Pu density of $5.5 \mathrm{~g} \mathrm{Pu} / \mathrm{cm}^{3}$, cease calciner operation or add impurities, such as magnesium nitrate, to the feed to dilute the plutonium. 
HNF-3908 Rev. 0

\subsubsection{Plutonium Metal Prohibition}

No plutonium metal shall be introduced into the Glovebox 188-1.

\subsubsection{Miscellaneous Glovebox Items}

A scale, non-container equipment, and non-container tools are allowed in the glovebox.

\subsubsection{Fire Fighting}

Fire fighting designation for the glovebox is Fire Fighting Category C.

\subsection{METHODOLOGY}

\subsection{REQUIREMENTS AND EXEMPTIONS}

This analysis must meet the requirements of HNF-PRO-537, Rev. 0 Criticality Safety Control of Fissionable Material (FDH 1997b), and HNF-PRO-539, Criticality Safety Evaluations (FDH 1997c). No exemptions apply to the evaluation in this document.

HNF-PRO-539 states that for all new operations and changes pertinent to criticality issues in existing operations, the CSER is required to "demonstrate that there is an acceptable margin of subcriticality for all normal and credible abnormal conditions" being considered.

The criteria used to demonstrate that subcriticality margins are acceptable, in this document, are given in HNF-PRO-537. The HNF-PRO-537 states that "the fraction of a critical dimension, volume, mass, etc. including allowance for accuracy, is equal to or less than 0.90 . When mass control is used and maintained only by administrative controls, the fraction of a critical mass set as the operational limit shall be $\leq 0.45$, unless double batching is not credible." The limits on $\mathrm{k}_{\text {eff }}$ calculated for systems is 0.95 for cases with limited experimental data and with relatively large but reasonable interpolations or extrapolations. All analyzed cases have materials whose cross sections were tested against benchmarked data. HNF-PRO-537 specifies a $0.90 \mathrm{k}_{\text {eff }}$ limit where no applicable experimental data exists.

The double contingency principle states: "Process designs shall incorporate sufficient factors of safety to require at lease two unlikely, independent and concurrent changes in process conditions 
before a criticality accident is possible." A criticality accident is interpreted to mean that critical mass or volume has been reached or exceeded. The CSER must show that the allowed fissile material configurations and any credible single contingency will not reach or exceed the critical mass or volume.

\subsection{ANALYTICAL METHOD}

\subsubsection{MONK Code}

The MONK6B code was used for the analyses in CSER 95-005 and its addendum. The MONK6B code is commercially licensed from the British ANSWERS organization. The MONK6B code uses cross sections from a point energy library based on the UKNDL and JEF evaluations. It was verified and validated on the Sun3 workstation in the Scientific Engineering Computer Center (SECC).

Appendix B provides a standardized summary for the documentation of the validation (Macklin and Miller 1992; Miller 1994) carried out for the MONK6B Monte-Carlo code, and its predecessor versions, as applicable to plutonium materials encountered at PFP. With the cross-section library supplied, the MONK6A/6B validation calculations indicate an allowed maximum $\mathrm{k}_{\text {eff }}$ value of 0.935 for new system calculations to assure subcriticality with an acceptable margin, including the uncertainties in the analytical methods and benchmark experimental data.

\subsubsection{MCNP Code}

The Monte Carlo code MCNP 4B was used in this criticality analysis for the base case calculations. MCNP 4B was certified by Schwinkendorf (1998). Values of $\mathrm{k}_{\text {eff }}$ in Table 8, Calculated Results Using MCNP Base Case, are from MCNP 4B. The plutonium validation is in Erickson (1998) and Lan (1999). A summary of the validation of MCNP 4B is included in Appendix A, MCNP 4B Computer Code Validation, which determines a maximum allowable $k_{\text {eff }}$ value of 0.942 for new system calculations with statistical uncertainties $\leq \pm 0.002$ to assure subcriticality with an acceptable margin, including the uncertainties in the analytical methods and benchmark experimental data.

\subsection{HAZOP/WHAT-IF ASSESSMENT}

Identification of contingencies for the operation described in Section 2.0 used a modified combination of the Hazard and Operability (HazOp) study technique and the What-If technique. The goal of the study is to identify deviations from the planned operation. The identified deviations may pose a challenge to criticality safety. Analysis is done as necessary to demonstrate that each identified condition satisfies the criticality safety criteria.

In a $\mathrm{HazOp}$, an interdisciplinary team uses a disciplined, systematic approach to identify hazard and operability deviations that could lead to undesirable consequences. Because the criticality safety concerns usually arise from deviations from the process design, an experienced team leader 
systematically guides the team through the plant design. The result is the "What-If" and "Hazard/Consequences" columns in the following assessment table, Table 4. The third column gives the safeguard determined in the comment column.

Appendix D, Criticality Hazards Identification and Assessment, contains a more complete discussion of the methods used in the HazOp as well information about the assessment team.

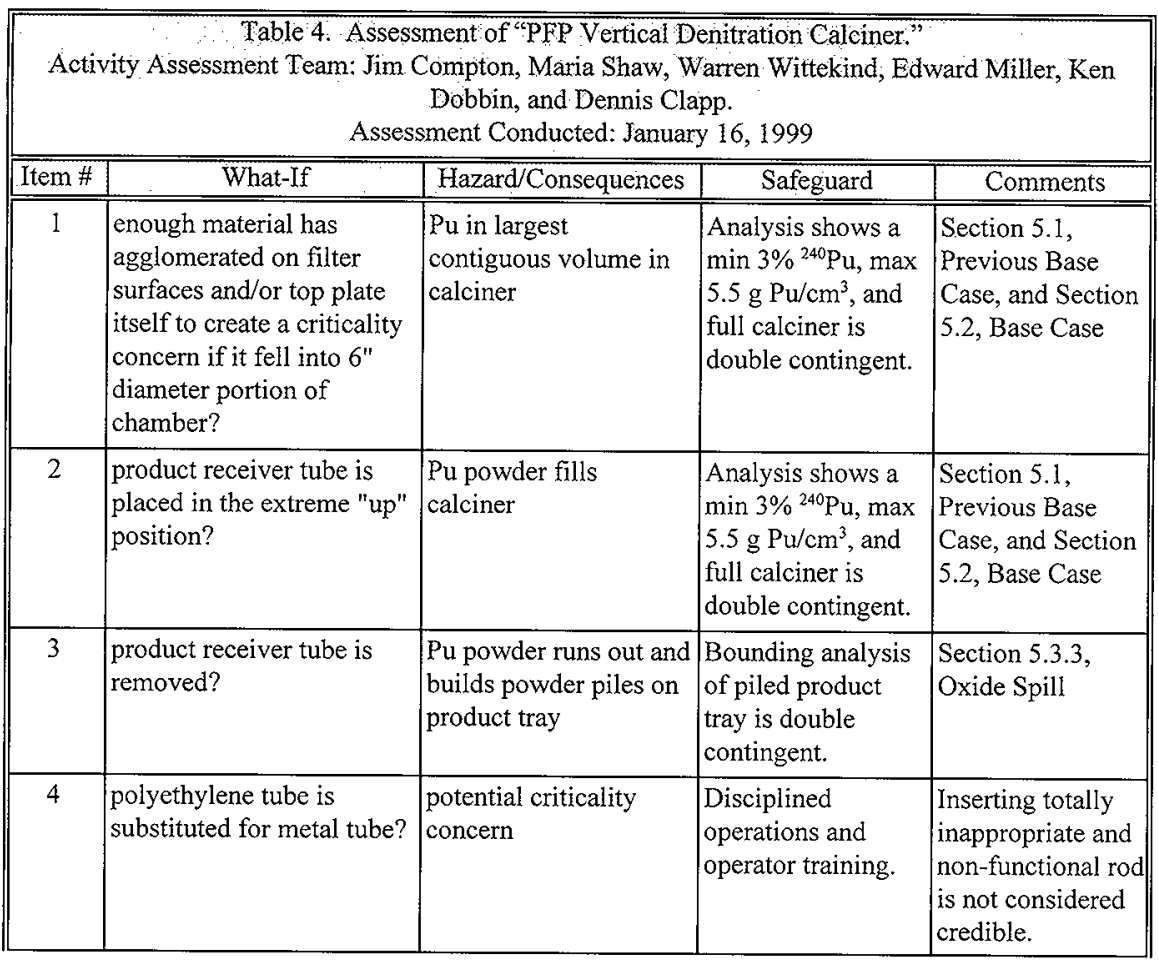




\begin{tabular}{|c|c|c|c|c|}
\hline \multicolumn{5}{|c|}{$\begin{array}{l}\text { Table 4. Assessment of "PFP Vertical Denitration Calciner" } \\
\text { Activity Assessment Team: Jim Compton, Maria Shaw, Warren Wittekind, Edward Miller, Ken } \\
\text { Dobbin, and Dennis Clapp. } \\
\text { Assessment Conducted: January } 16,1999\end{array}$} \\
\hline Item \# & What-If & Hazard/Consequences. & Safeguard & Comments \\
\hline 5 & $\begin{array}{l}\text { valve is operated at the } \\
\text { wrong time? }\end{array}$ & $\begin{array}{l}\text { A. Calciner filled with } \\
\text { Pu if closed when } \\
\text { calcining. } \\
\text { B. Spill Pu onto } \\
\text { product tray and floor } \\
\text { if opened and product } \\
\text { collection pot is not in } \\
\text { place }\end{array}$ & $\begin{array}{l}\text { A. Analysis shows } \\
\text { a min } 3 \%{ }^{240} \mathrm{Pu}, \\
\mathrm{max} 5.5 \mathrm{~g} \mathrm{Pu} / \mathrm{cm}^{3} \text {, } \\
\text { and full calciner is } \\
\text { double contingent. } \\
\text { B. Bounding } \\
\text { analysis of piled } \\
\text { product tray is } \\
\text { double contingent. }\end{array}$ & $\begin{array}{l}\text { A. Section } 5.1 \text {, } \\
\text { Previous Base } \\
\text { Case, and Section } \\
\text { 5.2, Base Case } \\
\text { B. Section 5.3.3, } \\
\text { Oxide Spill }\end{array}$ \\
\hline 6 & $\begin{array}{l}\text { product collection pot } \\
\text { breaks while operating or } \\
\text { filled? }\end{array}$ & $\begin{array}{l}\mathrm{Pu} \text { powder spills on } \\
\text { product tray/floor }\end{array}$ & $\begin{array}{l}\text { Bounding analysis } \\
\text { of piled product } \\
\text { tray is double } \\
\text { contingent. }\end{array}$ & $\begin{array}{l}\text { Section } 5.3 .3 \\
\text { Oxide Spill }\end{array}$ \\
\hline 7 & $\begin{array}{l}\text { clean acid is spilled on } \\
\text { main level floor? }\end{array}$ & $\begin{array}{l}\text { spill runs down to } \\
\text { basement floor with } \\
\text { entrained } \mathrm{Pu}\end{array}$ & $\begin{array}{l}\text { Bounding analysis } \\
\text { of } 3 / 8^{\prime \prime} \mathrm{Pu} \text { depth } \\
\text { and } 2^{\prime \prime} \text { of water is } \\
\text { double contingent }\end{array}$ & $\begin{array}{l}\text { Section } 5.1, \\
\text { Previous Base } \\
\text { Case, and Section } \\
5.2, \text { Base Case }\end{array}$ \\
\hline 8 & $\begin{array}{l}\text { acid bottle contents is } \\
\text { moved too close to } \\
\text { calciner body? }\end{array}$ & $\begin{array}{l}\text { increased reflection of } \\
\text { calciner }\end{array}$ & $\begin{array}{l}\text { Bounding analysis } \\
\text { of calciner with } \\
\text { wetted upper or } \\
\text { lower insulation is } \\
\text { double contingent. }\end{array}$ & $\begin{array}{l}\text { Section 5.1, } \\
\text { Previous Base } \\
\text { Case, and Section } \\
\text { 5.3.4, Acid Spill }\end{array}$ \\
\hline 9 & $\begin{array}{l}\text { acid is mistakenly added } \\
\text { to calciner through } \\
\text { pressure relief port? }\end{array}$ & $\begin{array}{l}\text { increasing moderation } \\
\text { in calciner }\end{array}$ & $\begin{array}{l}\text { Bounding analysis } \\
\text { of full calciner } \\
\text { flooded with } \mathrm{Pu} \\
\text { solution is double } \\
\text { contingent. }\end{array}$ & $\begin{array}{l}\text { Section } 5.1, \\
\text { Previous Base } \\
\text { Case, and Section } \\
\text { 5.2, Base Case }\end{array}$ \\
\hline 10 & $\begin{array}{l}\text { heater only is run without } \\
\text { feed input? }\end{array}$ & $\begin{array}{l}\text { heat may shrink Pu } \\
\text { crystals in calciner bed } \\
\text { with powder density } \\
\text { increase }\end{array}$ & $\begin{array}{l}\text { For less than } 6 \mathrm{~kg} \\
\text { in the calciner, up } \\
\text { to } 8 \mathrm{~g} \mathrm{Pu} / \mathrm{cm}^{3} \text { is } \\
\text { double contingent. }\end{array}$ & $\begin{array}{l}\text { Section } 5.3 .13, \\
\text { Oxide Density } \\
\text { Exceeded }\end{array}$ \\
\hline
\end{tabular}




\begin{tabular}{|c|c|c|c|c|}
\hline \multicolumn{5}{|c|}{$\begin{array}{l}\text { Table 4. Assessment of "PFP Vertical Denitration Calciner." } \\
\text { Activity Assessment Team: Jim Compton, Maria Shaw, Warren Wittekind, Edward Miller, Ken } \\
\text { Dobbin, and Dennis Clapp. } \\
\text { Assessment Conducted: January } 16,1999\end{array}$} \\
\hline Item \# & What-If & Hazard/Consequences & Safeguard & Comments \\
\hline 11 & $\begin{array}{l}\text { agitator is run without feed } \\
\text { input? }\end{array}$ & $\begin{array}{l}\text { comminuted crystals } \\
\text { with powder density } \\
\text { increase }\end{array}$ & $\begin{array}{l}\text { For less than } 6 \mathrm{~kg} \\
\text { in the calciner, up } \\
\text { to } 8 \mathrm{~g} \mathrm{Pu} / \mathrm{cm}^{3} \text { is } \\
\text { double contingent. }\end{array}$ & $\begin{array}{l}\text { Section } 5.3 .13 \\
\text { Oxide Density } \\
\text { Exceeded }\end{array}$ \\
\hline 12 & $\begin{array}{l}\text { liquid (of different } \\
\text { chemical composition) is } \\
\text { added to feed tank? }\end{array}$ & $\begin{array}{l}\text { dissolves } \mathrm{Pu} \text { oxide in } \\
\text { calciner }\end{array}$ & $\begin{array}{l}\text { Analysis shows a } \\
\min 3 \%{ }^{240} \mathrm{Pu} \text {, max } \\
5.5 \mathrm{~g} \mathrm{Pu} / \mathrm{cm}^{3} \text {, and } \\
\text { full calciner is } \\
\text { double contingent. }\end{array}$ & $\begin{array}{l}\text { Section } 5.1 \text {, } \\
\text { Previous Base } \\
\text { Case (Reactivity } \\
\text { is decreased by } \\
\text { dissolving } \\
5.5 \mathrm{~g} \mathrm{Pu} / \mathrm{cm}^{3} \text { in } \\
\text { solution that then } \\
\text { must be of lower } \\
\text { density) }\end{array}$ \\
\hline 13 & $\begin{array}{l}\text { fissile solution rather than } \\
\text { clean acid is added to the } \\
\text { calciner feed tank? }\end{array}$ & $\begin{array}{l}\text { increased mass and } \\
\text { moderation of } \mathrm{Pu} \text { in } \\
\text { calciner }\end{array}$ & $\begin{array}{l}\text { Analysis shows a } \\
\min 3 \%{ }^{240} \mathrm{Pu} \text {, max } \\
5.5 \mathrm{~g} \mathrm{Pu} / \mathrm{cm}^{3} \text {, and } \\
\text { full calciner is } \\
\text { double contingent. }\end{array}$ & $\begin{array}{l}\text { Section } 5.1, \\
\text { Previous Base } \\
\text { Case, and Section } \\
5.2 \text {, Base Case }\end{array}$ \\
\hline 14 & $\begin{array}{l}\mathrm{Pu} \text { is driven into the } \\
\text { scrubber? }\end{array}$ & $\begin{array}{l}\text { increasing } \mathrm{Pu} \\
\text { concentration in } \\
\text { scrubber and scrubber } \\
\text { system as a whole }\end{array}$ & $\begin{array}{l}\text { Bounding Analysis } \\
\text { filling scrubber } \\
\text { tanks with } \mathrm{Pu} \\
\text { solution and } 10^{\prime \prime} \text { of } \\
\text { Pu solids is double } \\
\text { contingent }\end{array}$ & $\begin{array}{l}\text { Section } 5.3 .5, \\
\text { Plutonium in } \\
\text { Scrubber System }\end{array}$ \\
\hline 15 & the feed system leaks? & $\begin{array}{l}\text { acid solution is spilled } \\
\text { to basement }\end{array}$ & $\begin{array}{l}\text { Bounding analysis } \\
\text { of } 3 / 8 \text { " Pu depth } \\
\text { and } 2 " \text { of water is } \\
\text { double contingent }\end{array}$ & $\begin{array}{l}\text { Section 5.1, } \\
\text { Previous Base } \\
\text { Case, and Section } \\
5.2, \text { Base Case }\end{array}$ \\
\hline 16 & there is excess air flow? & $\mathrm{Pu}$ cloud in calciner & $\begin{array}{l}\text { Analysis shows a } \\
\mathrm{min} 3 \%{ }^{240} \mathrm{Pu} \text {, max } \\
5.5 \mathrm{~g} \mathrm{Pu} / \mathrm{cm}^{3} \text {, and } \\
\text { full calciner is } \\
\text { double contingent. }\end{array}$ & $\begin{array}{l}\text { Section 5.1, } \\
\text { Previous Base } \\
\text { Case, and Section } \\
5.2, \text { Base Case }\end{array}$ \\
\hline
\end{tabular}




\begin{tabular}{|c|c|c|c|c|}
\hline \multicolumn{5}{|c|}{$\begin{array}{c}\text { Table 4. Assessment of "PFP Vertical Denitration Calciner," } \\
\text { Activity Assessment Team: Jim Compton; Maria Shaw, Warren Wittekind, Edward Miller, Ken } \\
\text { Dobbin, and Dennis Clapp. } \\
\text { Assessment Conducted January 16, 1999 }\end{array}$} \\
\hline Item \# & What-If & Hazard/Consequences. & Safeguard & Comments \\
\hline 17 & $\begin{array}{l}\text { more liquid volume than } \\
\text { heaters can handle? }\end{array}$ & $\begin{array}{l}\text { A. Flooding calciner } \\
\text { with acid solution and } \\
\text { increased moderation - } \\
\text { potential criticality } \\
\text { concern. } \\
\text { B. Overflow } \\
\text { production collection } \\
\text { pot. } \\
\text { C. Pu cloud in calciner } \\
\text { (too much feed } \\
\text { evaporating at once } \\
\text { with a steam pressure } \\
\text { buildup.) }\end{array}$ & $\begin{array}{l}\text { A. Bounding } \\
\text { analysis of full } \\
\text { calciner flooded } \\
\text { with Pu solution is } \\
\text { double contingent. } \\
\text { B. Bounding } \\
\text { analysis of piled } \\
\text { product tray is } \\
\text { double contingent. } \\
\text { C. Analysis shows } \\
\text { a min } 3 \%{ }^{240} \mathrm{Pu}, \\
\text { max } 5.5 \mathrm{~g} \mathrm{Pu} / \mathrm{cm}^{3} \text {, } \\
\text { and full calciner is } \\
\text { double contingent. }\end{array}$ & $\begin{array}{l}\text { B. Section 5.3.3, } \\
\text { Oxide Spill } \\
\\
\text { C. Section 5.1, } \\
\text { Previous Base } \\
\text { Case, and Section } \\
\text { 5.2, Base Case }\end{array}$ \\
\hline 18 & $\begin{array}{l}\text { Pu concentration in scrub } \\
\text { solution is too high? }\end{array}$ & $\begin{array}{l}\text { potential criticality } \\
\text { concern of Pu-water } \\
\text { mixture }\end{array}$ & $\begin{array}{l}\text { Bounding Analysis } \\
\text { filling scrubber } \\
\text { tanks with } \mathrm{Pu} \\
\text { solution and } 10^{\prime \prime} \text { of } \\
\text { Pu solids is double } \\
\text { contingent }\end{array}$ & $\begin{array}{l}\text { Section } 5.3 .5 \\
\text { Plutonium in } \\
\text { Scrubber System }\end{array}$ \\
\hline 19 & $\begin{array}{l}\text { too many PR can drums in } \\
\text { the room? }\end{array}$ & $\begin{array}{l}\text { potential criticality } \\
\text { concern }\end{array}$ & $\begin{array}{l}\text { Bounding analysis } \\
\text { of excess mass in } \\
\text { glovebox is double } \\
\text { contingent }\end{array}$ & \begin{tabular}{|l|} 
Section 5.1, \\
Previous Base \\
Case and \\
Section 5.3.11, PR \\
drum brought into \\
Room 188
\end{tabular} \\
\hline 20 & $\begin{array}{l}\text { wrong drums ( } 8 \text { liter PR } \\
\text { can) are brought into the } \\
\text { room? }\end{array}$ & $\begin{array}{l}\text { potential criticality } \\
\text { concern }\end{array}$ & $\begin{array}{l}\text { Bounding analysis } \\
\text { of excess mass in } \\
\text { glovebox is double } \\
\text { contingent }\end{array}$ & \begin{tabular}{|l|} 
Section 5.1, \\
Previous Base \\
Case and \\
Section 5.3.11, PR \\
drum brought into \\
Room 188
\end{tabular} \\
\hline
\end{tabular}




\begin{tabular}{|c|c|c|c|c|}
\hline \multicolumn{5}{|c|}{$\begin{array}{l}\text { Table 4. Assessment of "PFP Vertical Denitration Calciner," } \\
\text { Activity Assessment Team: Jim Compton, Maria Shaw, Warren Wittekind, Edward Miller, Ken } \\
\text { Dobbin, and Dennis Clapp. } \\
\text { Assessment Conducted January 16,1999 }\end{array}$} \\
\hline Item $\#$ & What If & Hazard/Consequences & Safeguard & Comments \\
\hline 21 & $\begin{array}{l}55 \text { gallon waste drum is } \\
\text { brought into the room? }\end{array}$ & $\begin{array}{l}\text { potential criticality } \\
\text { concern }\end{array}$ & $\begin{array}{l}\text { Bounding analysis } \\
\text { of excess mass in } \\
\text { glovebox is double } \\
\text { contingent }\end{array}$ & $\begin{array}{l}\text { Section 5.1, } \\
\text { Previous Base } \\
\text { Case and } \\
\text { Section 5.3.11, PR } \\
\text { drum brought into } \\
\text { Room } 188\end{array}$ \\
\hline 22 & $\begin{array}{l}10 \text { liter type containers } \\
\text { brought into the room? }\end{array}$ & $\begin{array}{l}\text { potential criticality } \\
\text { concern }\end{array}$ & $\begin{array}{l}\text { Bounding analysis } \\
\text { of excess mass in } \\
\text { glovebox is double } \\
\text { contingent }\end{array}$ & $\begin{array}{l}\text { Section } 5.1 \\
\text { Previous Base } \\
\text { Case, and Section } \\
5.2, \text { Base Case }\end{array}$ \\
\hline 23 & $\begin{array}{l}\text { room sprinkler water } \\
\text { enters glovebox? }\end{array}$ & $\begin{array}{l}\text { potential moderation } \\
\text { and reflection }\end{array}$ & $\begin{array}{l}\text { Flooding glovebox } \\
\text { is shown double } \\
\text { contingent }\end{array}$ & $\begin{array}{l}\text { Section } 5.1, \\
\text { Previous Base } \\
\text { Case, and Section } \\
\text { 5.3.7, Fire }\end{array}$ \\
\hline 24 & $\begin{array}{l}\text { Seismic - glovebox tilts to } \\
\text { the corner opposite the } \\
\text { criticality drain? }\end{array}$ & $\begin{array}{l}\text { Collection of spilled } \\
\text { calcine and liquids in } \\
\text { corner of glovebox for } \\
\text { mass, moderation, and } \\
\text { reflection }\end{array}$ & $\begin{array}{l}\text { Seismic analysis } \\
\text { shows collection of } \\
\text { material in } \\
\text { glovebox corner is } \\
\text { double contingent }\end{array}$ & $\begin{array}{l}\text { Section } 5.3 .6 \\
\text { Seismic }\end{array}$ \\
\hline 25 & $\begin{array}{l}\text { insulation on lower } \\
\text { calciner section wetted? }\end{array}$ & $\begin{array}{l}\text { increase in reflection of } \\
\text { calciner }\end{array}$ & $\begin{array}{l}\text { Flooding glovebox } \\
\text { is shown double } \\
\text { contingent }\end{array}$ & \begin{tabular}{|l|} 
Section 5.1, \\
Previous Base \\
Case, and Section \\
5.3 .7$, Fire \\
\end{tabular} \\
\hline
\end{tabular}

These identified "What-Ifs" are considered in Section 5.0, Evaluation and Results. For simplicity, the contingencies and the relevant analysis are tabulated in Table 5, Controlled Parameters, Controls, Limits and Contingency Analyses. 


\begin{tabular}{|c|c|c|c|}
\hline $\begin{array}{l}\text { Controlled } \\
\text { Parameter }\end{array}$ & Control & $\begin{array}{r}\text { Limit } \\
\text { Number }\end{array}$ & $\begin{array}{c}\text { Relevant } \\
\text { Contingency } \\
\text { Analysis }\end{array}$ \\
\hline Mass & $4.5 \mathrm{~kg}$ Pu glovebox total & 3.1 .1 & $5.1 \& 5.2$ \\
\hline Volume & $\begin{array}{l}\text { One } 4.2 \mathrm{~L} \text { feed polybottle, five } 0.5 \mathrm{~L} \text { polyjars or slip lid } \\
\text { containers, twenty } 30 \mathrm{ml} \text { sample bottles, maximum } 750 \mathrm{ml} \text { of } \\
\text { maintenance fluids. }\end{array}$ & 3.1 .3 & $5.1 \& 5.2$ \\
\hline Moderation & Hydrogenous materials limited in calciner & 3.1 .2 & $5.1 \& 5.2$ \\
\hline Interaction & 10 inch spacing requirement & 3.1 .4 & $5.1 \& 5.2$ \\
\hline Reflection & $\begin{array}{l}\text { No operation with wet calciner insulation } \\
\text { Rags limited to } 6 \mathrm{ft}^{2} \text { total area }\end{array}$ & $\begin{array}{l}3.2 .2 \\
3.2 .7\end{array}$ & $\begin{array}{l}5.3 .4 .4 \\
5.1 \& 5.2\end{array}$ \\
\hline Geometry & $\begin{array}{l}\text { Clean up fissile material spills before disassembly } \\
\text { Criticality drain not visibly obstructed } \\
\text { Clean up fissile material spills } \\
\text { Use of plastics is limited inside or outside glovebox } \\
\text { Fire fighting category C, no directed streams of } \mathrm{H}_{2} \mathrm{O} \\
\text { No liquids in sweeps containers }\end{array}$ & $\begin{array}{l}3.1 .7 \\
3.2 .5 \\
3.2 .6 \\
3.2 .8 \\
3.2 .9 \\
3.2 .10\end{array}$ & $\begin{array}{l}5.3 .4 \\
5.3 .8 \\
5.3 .3 \\
5.3 .7 .2 \\
5.3 .4\end{array}$ \\
\hline Isotopics & Min. 3 wt $\%{ }^{240} \mathrm{Pu}$, Max. wt $\%{ }^{241} \mathrm{Pu}=\left({ }^{240} \mathrm{Pu}\right.$ wt $\left.\%\right) / 5$ & 3.1 .1 & $5.1 \& 5.2$ \\
\hline Density & $\begin{array}{l}\text { Maximum } 5.5 \mathrm{~g} \mathrm{Pu} / \mathrm{cm}^{3} \\
\text { Maximum 5.5 g Pu/cm , dilute or cease operation. }\end{array}$ & $\begin{array}{l}3.1 .5 \\
3.2 .1\end{array}$ & $\begin{array}{l}5.3 .13 \\
5.3 .13\end{array}$ \\
\hline Concentration & No fissionable materials introduced & 3.2 .3 & $5.1 \& 5.2$ \\
\hline Poison & No controls for neutron poisons & & \\
\hline
\end{tabular}

\subsection{EVALUATION AND RESULTS}

\subsection{PREVIOUS BASE CASE}

The previous base case calculations were taken from CSER 95-005 (Geiger 1995a) and its addendum (Geiger 1995b). Salient features of that model are provided in the following sections and summarized in Table 6. That model used plutonium feed which is conservative to evaluate the calciner processing nitric acid feed that is to be evaluated in this CSER. For 6 inch diameter tanks, the most reactive feed is $140 \mathrm{~g} \mathrm{Pu} / \mathrm{cm}^{3} \mathrm{Pu}\left(\mathrm{NO}_{3}\right)_{4}$. This determination is made in this section.

The criticality safety of the vertical denitration calciner normal conditions with plutonium nitrate feed was assessed using the computer code MONK6B in CSER 95-005 (Geiger 1995a) and its addendum (Geiger 1995b). Appendix B discusses validation of the MONK6B code. This section presents the standard model of the denitrating calciner under normal conditions of plutonium nitrate 
feed which is conservative for the acid feed operation. It discusses each unit of the system in turn. Appendix B of CSER 95-005 contains an input listing for the MONK 6B standard model. Appendix C of CSER 95-005 presents a study of the effect of changing the location of the fission source in the model. The study, which concluded that the model was rather insensitive to different fission source locations, justifies the source used throughout the criticality safety assessment; a fission source distributed over the fissile material throughout the glovebox.

For the entire system, the Previous Base Case standard plutonium model had a $\mathrm{k}_{\text {eff }}$ of $0.8151 \pm 0.0030$. This value is well below the allowable $\mathrm{k}_{\text {eff }}$ of .935 for these systems.

\begin{tabular}{|c|c|}
\hline \multicolumn{2}{|c|}{ Table 6. Previous Base Case Model from CSER 95-005 } \\
\hline Glovebox Assumptions & $\begin{array}{l}\text { Process equipment can contain } 91 \ell \text { of liquid. } \\
\text { Capacity of floor up to criticality drain is } 144 \ell \text {. } \\
\text { Plutonium composition of } 2 \%{ }^{240} \mathrm{Pu} \text { and } 3 \%{ }^{241} \mathrm{Pu} \text {. } \\
\text { Plutonium nitrate was assumed to be the most reactive at a } \\
\text { concentration of } 140 \mathrm{~g} \text { Pu/ } \ell \text { for } 6 \text { in. diameter tanks. } \\
\text { Glovebox is surrounded with } 6 \text { in. of water for neutron } \\
\text { reflection. } \\
\text { Intermediate floor coated on top with } 0.3 \mathrm{~cm} \text { plutonium. } \\
\text { Bottom of glovebox has } 2 \text { in. deep water with } 3 / 8 \text { in. }(168 \mathrm{~kg}) \\
\text { plutonium. }\end{array}$ \\
\hline Glovebox dimensions & $\begin{array}{l}8 \mathrm{ft} \text { long by } 3 \mathrm{ft} 8 \text { in. wide by } 6 \mathrm{ft} 11 \mathrm{in} \text {. high. } \\
\text { Upper narrower section } 3 \mathrm{ft} \text { wide by } 3 \mathrm{ft} 1 \text { in. long by } 2 \mathrm{ft} 9 \mathrm{in} \text {. } \\
\text { high. } \\
\text { Lower narrower section } 3 \mathrm{ft} \text { wide by } 3 \mathrm{ft} 1 \text { in. long by } 3 \mathrm{ft} \text { high. } \\
\text { Intermediate floor in main box is } 5 \mathrm{ft} 10 \mathrm{in} \text {. below ceiling. } \\
\text { Criticality drain limits static depth of liquid to } 5.08 \mathrm{~cm}(2 \mathrm{in} \text {.). }\end{array}$ \\
\hline Feed polybottle & $\begin{array}{l}6 \mathrm{in.} \mathrm{OD}, 5.75 \mathrm{in} . \mathrm{ID}, 10.5 \mathrm{in} \text { t tall and holds } 4.2 \ell . \\
\text { Polyethylene walls are } \mathrm{C} \text { and } \mathrm{H} . \\
\text { Bottle holds } 0.59 \mathrm{~kg} \text { of plutonium for } 140 \mathrm{~g} \mathrm{Pu} / \ell \text { solution. }\end{array}$ \\
\hline Feed tank & $\begin{array}{l}\text { Borosilicate glass with } 6.19 \mathrm{in} \text {. ID, wall thickness of } 0.2 \mathrm{in} . \\
\text { Holds } 5.2 \ell \text { and is spaced } 16 \mathrm{in} \text {. from both calciner and } \\
\text { scrubber. } \\
\text { Sits on } 1 \text { in. thick polyvinyl chloride slab. } \\
\text { Volume modeled as } 5.9 \ell \text { holding } 0.8 \mathrm{~kg} \text { of plutonium. }\end{array}$ \\
\hline Diaphragm feed pump & $\begin{array}{l}\text { Has chamber } 2.88 \text { in. diameter and } 2.1 \text { in. long. } \\
\text { Volume is } 0.9 \ell \text { and holds } 0.13 \mathrm{~kg} \text { of plutonium. }\end{array}$ \\
\hline
\end{tabular}




\begin{tabular}{|c|c|}
\hline Calciner & $\begin{array}{l}\text { Two sections of } 6 \text { in. schedule } 10,310 \text { stainless steel pipe. } \\
\text { Upper filtering section is surrounded with } 3 \text { in. thick water- } \\
\text { saturated } 10 \% \text { alumina-and-silica insulation; } \\
\text { Upper section Volume of } 4.2 \ell \text { containing } 21 \mathrm{~kg} \text { of plutonium } \\
\text { oxide. } \\
\text { Lower calcining section is an annulus between the outer } 6 \text { in. } \\
\text { and inner } 4 \text { in. schedule } 10,310 \text { stainless steel pipe; interior of } \\
\text { inner pipe is left empty; } \\
3 \text { in. thick aluminum-and-silica insulation surrounds outside of } \\
\text { lower } 6 \text { in. pipe; lower section volume of } 2 \ell \text { and contains } 10 \mathrm{~kg} \\
\text { of plutonium oxide. } \\
\text { Upper and lower sections bolted together, forming continuous } \\
\text { void space. } \\
\text { Calciner is spaced } 16 \text { inches from both feed tank and scrubber. } \\
\text { Calciner is filled with plutonium oxide with a density of } \\
5 \mathrm{~g} / \mathrm{cm}^{3} \text {. } \\
\text { Total mass of plutonium in calciner is } 31 \mathrm{~kg} \text { in this base model. }\end{array}$ \\
\hline Scrubber & $\begin{array}{l}6 \text { in. quartz pipe filled with plutonium nitrate solution. } \\
\text { Spiral torus of } 304 \text { stainless steel pipe contains cooling water. } \\
\text { Solids modeled as plutonium oxide at } 2 \mathrm{~g} / \mathrm{cm}^{3} \text {. } \\
\text { Volume of } 21 \ell \text { contains } 3 \mathrm{~kg} \text { of plutonium in solution. }\end{array}$ \\
\hline Scrub Solution Catch Tanks & $\begin{array}{l}6.19 \text { in. ID borosilicate pipes. } \\
\text { Tanks spaced } 16 \text { inches apart. } \\
\text { Combined capacity of } 47 \text { e contains } 6.6 \mathrm{~kg} \text { of plutonium in } \\
\text { solution. }\end{array}$ \\
\hline Product Receiver & $\begin{array}{l}\text { Cylindrical container } 3.5 \text { in. ID and } 6 \text { in. high. } \\
\text { Volume of } 0.95 \ell \text { filled with } 5 \mathrm{~g} / \mathrm{cm}^{3} \text { dry plutonium oxide for a } \\
\text { mass of } 4.7 \mathrm{~kg} \text { plutonium. }\end{array}$ \\
\hline Load out Containers & $\begin{array}{l}1 \text { Pound slip lid cans } 3.5 \mathrm{in} \text {. ID and } 3.5 \mathrm{in} \text {. tall. } \\
\text { Total volume of } 1.1 \ell \text { and capacity of } 5.5 \mathrm{~kg} \text { of plutonium. }\end{array}$ \\
\hline
\end{tabular}

\subsubsection{Feed Solution}

The fissile material to be processed in this system is variable, but all solutions contain plutonium with at least $3 \%{ }^{240} \mathrm{Pu}$ (Hess 1994). None of the solutions listed in Hess (1994), contained more than $1 \%{ }^{241} \mathrm{Pu}$. Laboratory records were reexamined for this CSER with a representative set of isotopic analyses presented in Table 7 showing that ${ }^{241} \mathrm{Pu}$ is less than $0.5 \mathrm{wt} \%$. To help account for additional fissionables and ensure conservativity the actinide content in these solutions is assumed to be $3 \%{ }^{241} \mathrm{Pu}$ and only $2 \%{ }^{240} \mathrm{Pu}$ in the standard model. This assumption is highly conservative and yields a plutonium more reactive than could be derived from any un-enriched source. 
Uranium enriched to $1.25 \mathrm{wt} \%$ or less may be processed in the calciner because uranium is significantly less reactive than ${ }^{239} \mathrm{Pu}$ with $3 \mathrm{wt} \%{ }^{240} \mathrm{Pu}$ until the uranium enrichment exceeds $50 \mathrm{wt} \%$.

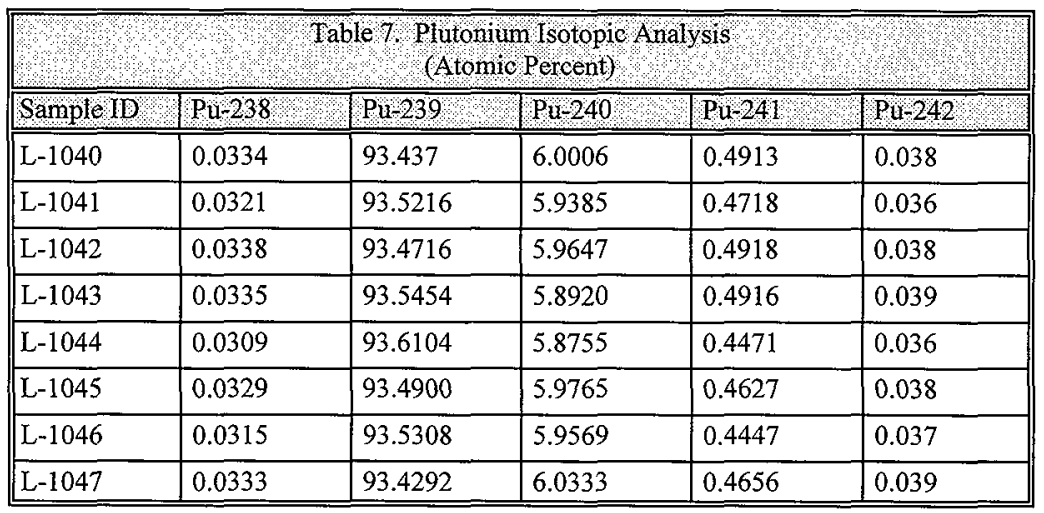

The most reactive plutonium composition for volume limited situations was demonstrated by CSER 97-004 (Table 1 in Hillesland 1997) to be the highest Pu concentration. Hillesland demonstrated that for $\mathrm{PuO}_{2}$ densities up to $6.0 \mathrm{~g} \mathrm{Pu} / \mathrm{cm}^{3}$, the most reactive "mud" mixture was formed by the highest plutonium density $\left(6.00 \mathrm{~g} \mathrm{Pu} / \mathrm{cm}^{3}\right) \mathrm{PuO}_{2}$, fully saturated with $450 \mathrm{~g} \mathrm{Pu} / \ell$ solution. This was for a thin layer on the glovebox floor or within confined volumes of calciner or product receiver. This also assumed that $\mathrm{Pu}$ metal was not available.

The most reactive plutonium composition for the feed tank, scrubber, and scrubber catch tanks was chosen as the minimizing radius of an infinite cylinder of solution. Graph III.A.4.97-1 from ARH-600 (Carter 1968) provides minima at $135 \mathrm{~g} \mathrm{Pu} / \ell$ unreflected and $145 \mathrm{~g}$ Pu/ $/$ reflected for aqueous plutonium nitrate containing $3 \%{ }^{240} \mathrm{Pu}$ and no excess acid. Therefore, a concentration of $140 \mathrm{~g} \mathrm{Pu} / \mathrm{l}$ was chosen for the most reactive plutonium feed solution. Hillesland (1997) also demonstrates that the $140 \mathrm{~g} \mathrm{Pu} / \mathrm{l}$ concentration is optimally moderated and is more reactive than the $450 \mathrm{~g} \mathrm{Pu} / \mathrm{l}$ in the 6 inch diameter Pyrex ${ }^{\mathrm{TM}}$ tanks.

\subsubsection{Calcine $\left(\mathrm{PuO}_{2}\right)$ Product}

The density of the calcine was expected to be $3.0 \mathrm{~g} \mathrm{Pu} / \mathrm{cm}^{3}$. Previous experience at PFP indicated it would be quite difficult to exceed a density of $5.0 \mathrm{~g} \mathrm{Pu} / \mathrm{cm}^{3}$. Therefore CSER 95-005 used a density of $5.0 \mathrm{~g} \mathrm{Pu} / \mathrm{cm}^{3}$ for the calcine (Geiger 1995a). This is also the maximum expected density of the calcine for normal operations. The analysis using $5.0 \mathrm{~g} \mathrm{Pu} / \mathrm{cm}^{3}$ establishes the limit of $5.5 \mathrm{~g} \mathrm{Pu} / \mathrm{cm}^{3}$. Figure III.A.9(100)-9 in ARH-600 shows that the minimum critical mass for the density range of 5.0 to $5.5 \mathrm{~g} \mathrm{Pu} / \mathrm{cm}^{3}$ is constant. Using $5.0 \mathrm{~g} \mathrm{Pu} / \mathrm{cm} 3$ is equivalent to $5.5 \mathrm{~g} \mathrm{Pu} / \mathrm{cm}^{3}$ in calculations. 
HNF-3908 Rev. 0

\subsubsection{Mud}

The "mud" was modeled as $\mathrm{PuO}_{2}$ saturated with water, and was located on the glovebox floor. The glovebox floor is assumed to contain $5.08 \mathrm{~cm}(2 \mathrm{in}$.) of water with $0.95 \mathrm{~cm}(3 / 8 \mathrm{in}$.) layer of mud under it. The basis for use of this composition mud is established in Section 2.1.1.4.

\subsubsection{Precipitated Pu Solids in Tanks}

Precipitated plutonium solids may accumulate in the bottom of the scrubber because the scrub solution is basic. Therefore, the base case modeled these solids as a mixture of oxide $\left(2 \mathrm{~g} / \mathrm{cm}^{3} \mathrm{of}\right.$ plutonium) with the interstitial void spaces filled by feed solution in a $25.4 \mathrm{~cm}(10 \mathrm{in}$.) layer at the bottom of the scrubber.

\subsubsection{Glovebox}

The glovebox is modeled as a box of $304 \mathrm{~L}$ stainless steel, with the dimensions described in Section 2.1.2. The atom densities listed in Carter 1968 (p. II.F.1-6) are used for this material. Because ARH-600 Carter (1968), page II.E-2, shows that reflector savings does not increase with more than $15 \mathrm{~cm}$ ( $6 \mathrm{in}$.) of water, the glovebox is surrounded by a minimum of $15 \mathrm{~cm}$ (6 in.) of water. This close filling water reflection is more reactive than fissile material moved in adjacent rooms or hall. The intermediate floor of the glovebox is assumed to be coated on top with $0.3 \mathrm{~cm}(0.12 \mathrm{in}$.) of $\mathrm{Pu}$ $\left(\mathrm{NO}_{3}\right)_{4} \cdot 5 \mathrm{H}_{2} \mathrm{O}$ plutonium. This layer conservatively bounds the reactivity of a $1 / 2 \ell$ container or sample bottles on this main floor.

\subsubsection{Criticality Drain}

To protect against spills of liquids accumulating to too great a depth, the glovebox contains a bottom-mounted criticality drain. This $7.6 \mathrm{~cm}(3 \mathrm{in}$.) diameter drain projects $5.08 \mathrm{~cm}(2 \mathrm{in}$.) into the glovebox. The drain limits the static depth of water in the glovebox to $5.08 \mathrm{~cm} \mathrm{(2} \mathrm{in.).} \mathrm{Consequently,}$ the bottom of the glovebox is assumed to be $5.08 \mathrm{~cm}(2 \mathrm{in}$.) deep in water, with $0.95 \mathrm{~cm}(3 / 8 \mathrm{in}$.) of plutonium oxide on the bottom. With these assumptions, the glovebox basement can hold $180 \mathrm{l}$ of solution (with no calcine) or $144 \ell$ of liquid on top of the mud. A layer of calcine $0.95 \mathrm{~cm}(3 / 8 \mathrm{in}$.) deep would contain $168 \mathrm{~kg}$ of plutonium. Note that the tanks and vessels in the glovebox contain a total volume of $91 \mathrm{\ell}$, as compared to the minimum $180 \mathrm{\ell}$ basement capacity of the glovebox floor. Therefore, if all of the vessels spill into a dry glovebox, there will be less liquid in the glovebox basement than is assumed in the standard model. Furthermore, nothing will flow out of the glovebox onto the floor of the room. 
HNF-3908 Rev. 0

\subsubsection{Vertical Calciner}

The model of the calciner closely matches the description in Section 2 filled with calcine. Notable departures are:

1. The filters are modeled as solid silicon carbide instead of porous

2. The calcining region is filled with calcined powder and does not include the mixer

3. The inside plug of the annulus is left empty of everything, including the heating element.

The filtering segment of the calciner is modeled as surrounded with $7.62 \mathrm{~cm}(3 \mathrm{in}$.$) of water-$ saturated $10 \%$ alumina-and-silica insulation, with the physical and chemical properties of the calcining section insulation. The calcined powder is assumed to be $\mathrm{PuO}_{2}$, with a density of $5 \mathrm{~g} / \mathrm{cm}^{3}$ of plutonium. (As a result of the analyses in CSER 95-005 [Geiger 1995a] the insulation on the filtering section of the calciner was changed to metal reflective insulation that doesn't absorb water but included water at $0.1 \mathrm{~g} / \mathrm{cm}$. . The effect of this change in insulation was calculated in the Addendum of CSER 95-005 [Geiger 1995b].)

The filtering section of the calciner has a volume of $4.2 \ell$ available to calcined powder, and can therefore contain $21 \mathrm{~kg}$ of plutonium at $5 \mathrm{~g} / \mathrm{cm}^{3}$. The calcination section has an available volume of $2 \ell$ and a capacity of $10 \mathrm{~kg}$. Therefore, the calciner holds a total of $31 \mathrm{~kg}$ of calcined plutonium (Geiger 1995a).

\subsubsection{Feed System}

5.1.8.1 Feed Polybottle. The feed polybottle is described on page 28 of Hess (1994). The outside diameter is given as 6 in. The inside dimension is expressed as $425 \mathrm{~g}$ of water per inch of height. Assuming $1 \mathrm{~g}$ of water takes up exactly $1 \mathrm{~cm}^{3}$, the internal radius of the container is $7.298 \mathrm{~cm}$ ( $2.873 \mathrm{in}$.), and the wall thickness is $0.322 \mathrm{~cm}(0.127 \mathrm{in}$.). The completely full volume of the polybottle is given as $4.20 \mathrm{l}$ (Compton 1999e). Assuming the inside is perfectly cylindrical, this gives a solution cylinder height of $25.101 \mathrm{~cm}(9.882 \mathrm{in}$.). Assuming a constant wall thickness, the outside height of the polybottle is $25.745 \mathrm{~cm}$ (10.136 in.), and the wall volume is $496 \mathrm{~cm}^{3}(1.05 \mathrm{pt}$.). The tare mass of the polybottle is given as $420 \mathrm{~g}$, which yields a density of $0.846 \mathrm{~g} / \mathrm{cm}^{3}$ - a reasonable value for low density polyethylene.

Accordingly, the polybottle is modeled as two concentric cylinders, with an inner cylinder of solution $25.101 \mathrm{~cm}$ tall with a radius of $7.298 \mathrm{~cm}$, surrounded by a low density polyethylene cylinder $25.745 \mathrm{~cm}$ tall with a radius of $7.620 \mathrm{~cm}$. The concentrations of carbon and hydrogen in the polyethylene are taken as 0.036333 and 0.072666 nuclei/barn-cm, respectively.

With a volume of $4.2 \ell$, a polybottle would hold $0.59 \mathrm{~kg}$ of plutonium assuming worst case solution. To maximize the reactivity contribution of the polybottle, the standard model assumes it touches both the feed tank and the outer surface of the insulation surrounding the calciner.

5.1.8.2 Feed Tank. The feed tank is a 5.2 l nominal capacity cylinder of borosilicate glass, consisting of a standard sized 6 in. diameter, 12 in. long pipe. This translates into an inside radius of 
$7.856 \mathrm{~cm}$, a wall thickness of $0.502 \mathrm{~cm}$, and a height of $30.480 \mathrm{~cm}$. The feed tank is open at the top. The wall composition is taken from page II.F.1-6 of Carter 1968. The design drawing shows the pipe sitting on a slab of polyvinyl chloride $1 \mathrm{in}$. thick. This stab is modeled as a disk of polyvinyl chloride, $2.54 \mathrm{~cm}$ thick with a radius of $13.970 \mathrm{~cm}$.

With a volume of $5.9 \ell$, the feed tank can hold $0.8 \mathrm{~kg}$ of plutonium when filled with $140 \mathrm{~g} \mathrm{Pu} / \ell$ solution.

5.1.8.3 Diaphragm Feed Pump. Information on the feed pump is rather scanty. The manufacturers catalogue gives dimensions for the largest diaphragm chamber only, while noting that some pumps are smaller. Accordingly, the pump is modeled at the maximum size: a fissile solution cylinder with a diameter of $7.315 \mathrm{~cm}$ and a horizontal axis of $5.334 \mathrm{~cm}$. This corresponds to a volume of $0.9 \ell$, with a worst-case holdup of $0.13 \mathrm{~kg}$ of plutonium when filled with $140 \mathrm{~g} \mathrm{Pu} / \ell$ solution.

\subsubsection{Scrubber System}

The scrubber system is made up of:

- The scrubber, a 6 inch diameter, $117.76 \mathrm{~cm}$ (46 5/8 in.) high Pyrex ${ }^{\mathrm{TM}}$ glass pipe used as approximately a $20 \ell$ tank,

The scrub solution catch tanks, two $22 \ell$ tanks receiving spent scrub solution, A chilled water supply, in adjacent room 187, with a 5 gallon capacity, and

A vacuum trap that connects to the plant process vacuum system.

The contamination of the cooling water supply with solution from the scrubber is considered incredible and the cooling water supply is not modeled in the base model. The scrub solution is pumped into the scrubber through the scrub solution pump from a scrub solution reservoir and, because of location, geometry, and incredibility of back flow against a pump head and gravity, is not considered in this criticality analysis. Also, the vacuum trap is not modeled because the other scrubber tanks are conservatively modeled full of plutonium solution and the vacuum trap is much smaller and even less likely to get any plutonium solution than the other tanks.

5.1.9.1 Scrubber. The scrubber is modeled as a vertical section of Pyrex ${ }^{\mathrm{TM}}$ glass tubing $7.856 \mathrm{~cm}$ (3.093 in.) inside radius, $8.358 \mathrm{~cm}$ (3.29 in.) outside radius, and $117.76 \mathrm{~cm}$ (46.36 in.) high. The scrubber system is cooled by a $91 \mathrm{~cm}$ ( $36 \mathrm{in}$.) high cooling coil of $1.3 \mathrm{~cm}(0.5 \mathrm{in}$.) diameter 307 stainless steel with a $0.089 \mathrm{~cm}(0.035$ in.) thick wall. The inside diameter of the cooling coil is $9.84 \mathrm{~cm}(3.875 \mathrm{in}$.) while the outside diameter is $12.38 \mathrm{~cm}(4.875 \mathrm{in}$.). There is a feed pipe $112.68 \mathrm{~cm}$ high and $0.95 \mathrm{~cm}$ outside radius, and $0.80 \mathrm{~cm}$ inside radius. There is an overflow pipe $112.76 \mathrm{~cm}$ (44.37 in.) high that is filled with $140 \mathrm{~g} \mathrm{Pu} / \mathrm{l}$ feed solution. The MONK standard model (case DeNO3as in Geiger 1995a) includes 33 in. height of $140 \mathrm{~g} \mathrm{Pu} / \ell \mathrm{Pu}\left(\mathrm{NO}_{3}\right)_{4}$ solution on top of a $25.4 \mathrm{~cm}$ (10 in.) thickness of $2 \mathrm{~g} \mathrm{Pu} / \mathrm{cm}^{3}$ precipitate in the scrubber. The $140 \mathrm{~g} \mathrm{Pu} / \mathrm{l}$ layer contains a modeled mass of $1.72 \mathrm{~kg} \mathrm{Pu}$. The $2 \mathrm{~g} \mathrm{Pu} / \mathrm{cm}^{3}$ precipitate $25.4 \mathrm{~cm}$ (10 in.) layer contains a modeled mass of 7.39 $\mathrm{kg} \mathrm{Pu}$. This adds to a modeled mass of $9.11 \mathrm{~kg}$ Pu in the scrubber.

5.1.9.2 Scrub Solution Catch Tanks. Each scrub solution catch tank is modeled as $7.82 \mathrm{~cm}$ (3.08 in.) inside radius $122.42 \mathrm{~cm}$ (48.2 in.) inside height, and $8.32 \mathrm{~cm}$ (3.27 in.) outside radius and 
$122.92 \mathrm{~cm}$ (48.39 in.) outside height. The standard model (case DeNO3as in Geiger 1995a) also included the waste scrub solution storage tanks with a conservative 23.4 liter nominal volume filled with a $140 \mathrm{~g} \mathrm{Pu} / \mathrm{l}$ feed $\mathrm{Pu}\left(\mathrm{NO}_{3}\right)_{4}$ solution in each tank. This models each storage tank containing $3.28 \mathrm{~kg}$ of $\mathrm{Pu}$.

\subsubsection{Containers}

5.1.10.1 Product Receiver. The product receiver is modeled as full of $5 \mathrm{~g} / \mathrm{cm}^{3}$ of absolutely dry $\mathrm{PuO}_{2}$. The walls are modeled with the same composition as the feed tank. For conservatism, the model does not take the bottom rounding into account. The inside is modeled as a cylinder of radius $4.445 \mathrm{~cm}$ and height $15.24 \mathrm{~cm}$. The external dimensions of the model are $15.716 \mathrm{~cm}$ high with a radius of $4.921 \mathrm{~cm}$. This model yields an internal volume of $0.95 \ell$ and a mass capacity of $4.7 \mathrm{~kg}$ of actinide, which is more plutonium than contained in the entire glovebox so it can bound having sample bottles and two $1 / 2 \ell$ containers.

5.1.10.2 Load Out Container. The load out container, a 1 pound slip lid can, is a steel cylinder $3 \frac{1}{2}$ in. tall and $3 \frac{1}{2}$ in. in diameter, with a capacity of $0.55 \ell$. For conservatism, the inside is modeled as a cylinder $8.89 \mathrm{~cm}$ in height with a radius of $4.445 \mathrm{~cm}$. The outside dimensions are 8.99 $\mathrm{cm}$ in tall and $4.495 \mathrm{~cm}$ radius. There are two of these containers, one on each vertex of the triangular load out pan away from the product receiver. Together, the load out containers have a volume of $1.1 \ell$, and a capacity of $5.5 \mathrm{~kg}$ of actinide.

5.1.10.3 Other Containers. Three additional $0.5 \ell$ containers, one a sweeps container with $<100 \mathrm{~g} \mathrm{Pu}$ and an $\mathrm{H} / \mathrm{x} \leq 20$, twenty $30 \mathrm{ml}$ sample vials, and maintenance fluid containers of up to $750 \mathrm{~m} \ell$ are not explicitly covered in the base case. However, they are covered by the overly conservative modeling of fissile material in the feed tank and scrubber system.

\subsubsection{Entire System}

The calciner is full of $31 \mathrm{~kg}$ of dry calcine. The tanks and vessels in the glovebox can contain a total of $91 \ell$ with $144 \ell$ in the basement on the glovebox floor above the mud layer on the floor. The extremely conservative base case MONK6B model had a $\mathrm{k}_{\mathrm{cff}}$ of $0.8151 \pm 0.003$ (Geiger 1995a).

\subsection{BASE CASE}

There are several differences between the base case MCNP4B computer model described here and the MONK6B computer model previous base case described in CSER 95-005 (Geiger 1995a) and in Section 5.1 above. The models of the scrubber and calciner are not as detailed but are more conservative. The $1 \mathrm{~cm}(3 / 8 \mathrm{in}$.) thick layer of oxide on the floor of the glovebox and the layer of plutonium pentahydrate on the intermediate floor are not included. Neither are several piles of "mud" underneath and adjacent to the containers. A plutonium oxide density of $5.5 \mathrm{~g} \mathrm{Pu} / \mathrm{cm}^{3}$ was used in this model compared to the $5.0 \mathrm{~g} \mathrm{Pu} / \mathrm{cm}^{3}$ used in the CSER 95-005 (Geiger 1995a) model. A $2.54 \mathrm{~cm}$ ( 1 in.) thick layer of water was included completely surrounding (sides, top, and bottom, if exposed) 
every container and vessel in the glovebox to conservatively represent hands. A $30.48 \mathrm{~cm}$ (12 in.) thick layer of water surrounds the entire glovebox. All of the ${ }^{10} \mathrm{~B}$ in the borosilicate glass vessels (feed tank, product receiver, scrubber waste tanks) was removed from the compositions in the MCNP models. The MCNP model of the calciner arrangement is described below.

\subsubsection{Concentration and isotopic composition of the fissile material}

The fissile composition in the model is the same as that used in CSER 95-005 (Geiger 1995a). The plutonium material to be processed in this system is variable, but solutions contain at least $3 \%$ ${ }^{240} \mathrm{Pu}$ (Hess 1994). Table 7 shows a sampling of the isotopic analysis of the plutonium in the calciner. For conservatism, the plutonium isotopics are assumed to be $3 \%{ }^{241} \mathrm{Pu}$ and only $2 \%{ }^{240} \mathrm{Pu}$.

The plutonium feed solution is modeled as a mixture of plutonium nitrate and water. The optimum reactivity concentration of $140 \mathrm{~g} \mathrm{Pu} / \mathrm{l}$ was used for the plutonium solution in 6 inch diameter vessels.

The dry calcine product is modeled as pure $\mathrm{PuO}_{2}$ powder with a concentration of $5.5 \mathrm{~g} \mathrm{Pu} / \mathrm{cm}^{3}$.

\subsubsection{Glovebox}

The glovebox is modeled as boxes of $304 \mathrm{~L}$ stainless steel. The main section is divided into upper and lower levels by an intermediate floor of 304L stainless steel. The attic and annex are separate boxes attached to one end of the glovebox with open access to the main section. The glovebox is surrounded on all sides with $30.48 \mathrm{~cm}$ of water. The lowest floor of the main section and the basement are covered to a depth of $5.08 \mathrm{~cm}(2$ in.) with water. The upper level of the main section of the glovebox contains the calciner, the scrubber, the feed tank, and one $4.2 \ell$ feed bottle. The lowest level of the main section contains the calciner product collection tube, the product receiver vessel, two load out containers, the diaphragm pump, and portions of the two scrubber waste collection tanks. The basement contains the remaining portions of the two scrubber waste collection tanks.

\subsubsection{Feed polybottle}

The feed polybottle is modeled as two concentric cylinders, with an inner cylinder of solution $25.101 \mathrm{~cm}$ tall with a radius of $7.298 \mathrm{~cm}$, surrounded by a low density polyethylene cylinder $25.745 \mathrm{~cm}$ tall with a radius of $7.620 \mathrm{~cm}$. The polybottle has a volume of $4.2 \ell$ and contains $588 \mathrm{~g}$ of plutonium when filled with $140 \mathrm{~g}$ Pu/ $\ell$ solution.

\subsubsection{Feed tank}

The feed tank is modeled as two concentric cylinders, with an inner cylinder of solution $30.48 \mathrm{~cm}$ tall with a radius of $7.856 \mathrm{~cm}$, surrounded by a cylinder of Pyrex ${ }^{\mathrm{TM}}$ glass with an outer radius of $8.358 \mathrm{~cm}$. This glass feed tank is modeled without any ${ }^{10} \mathrm{~B}$ in the glass. The feed tank is sitting on a disk of polyvinyl chloride $2.54 \mathrm{~cm}$ thick with a radius of $13.970 \mathrm{~cm}$. The tank has a volume of $5.9 \mathrm{l}$ and contains $827 \mathrm{~g}$ of plutonium when filled with $140 \mathrm{~g} \mathrm{Pu} / \mathrm{l}$ solution. 


\subsubsection{Diaphragm feed pump}

The diaphragm feed pump is modeled as a cylinder with a diameter of $7.315 \mathrm{~cm}$ and a horizontal axis of $5.334 \mathrm{~cm}$. The pump has a volume of $0.9 \ell$ and contains $125 \mathrm{~g}$ of plutonium when filled with $140 \mathrm{~g} \mathrm{Pu} / \mathrm{l}$ solution.

\subsubsection{Vertical calciner}

The outer vessel of the calciner consists of two sections of 310 stainless steel, 6 inch schedule 10 pipe. This pipe is modeled with an inner radius of $8.07339 \mathrm{~cm}$ and an outer radius of $8.41375 \mathrm{~cm}$. The overall height of the calciner is $59.69 \mathrm{~cm}$.

The heating and agitation of the product take place in the lower portion of the calciner. There is a dome made from 4 inch pipe and pipe cap in the center, which is modeled as extending up $18.91 \mathrm{~cm}$ into the internal volume of the calciner from the bottom. No credit is taken for the volume occupied by the agitator, except that the rod is modeled as having its lower end $2.54 \mathrm{~cm}$ above the top of the dome. The product collection tube is modeled as a cylinder with a radius of $1.11633 \mathrm{~cm}$ extending from inside the dome to the product receiver vessel.

The upper section contains three filtering elements and the agitator rod. Each filter element is modeled as a hollow cylinder of silicon carbide $30.48 \mathrm{~cm}$ tall with an outside radius of $2.54 \mathrm{~cm}$, an inside radius of $1.4351 \mathrm{~cm}$, and a bottom thickness of $3.810 \mathrm{~cm}$. The inner volume of the filters are empty in this model.

The inside of both the upper and lower sections of the calciner and the product collection tube are modeled as filled with dry plutonium oxide powder at a density of $5.5 \mathrm{~g} \mathrm{Pu} / \mathrm{cm}^{3}$. The lower section, upper section and product collection tube have volumes of $2.4 \ell, 4.4 \ell$, and $0.118 \ell$, respectively, resulting in plutonium masses of $13,325 \mathrm{~g}, 24,218 \mathrm{~g}$, and $648 \mathrm{~g}$ when filled with plutonium oxide at $5.5 \mathrm{~g} \mathrm{Pu} / \mathrm{cm}^{3}$.

The lower section of the calciner is surrounded by $11.43 \mathrm{~cm}$ ( $4.5 \mathrm{in}$.) of insulation. All calculations include water saturation of this insulation as part of the normal condition as a conservatism to represent spills of non-fissile solutions and condensation buildup when the calciner is cooled down.

The upper section of the calciner is surrounded by $7.62 \mathrm{~cm}(3 \mathrm{in}$.) of metal reflective insulation that does not absorb liquids. The insulation is conservatively modeled as being $10 \%$ density $304 \mathrm{~L}$ steel to accommodate the concentric sheets and narrow strips of sheet metal used to create many of the spaces of dead air within the insulation. Water at $10 \%$ density was also added to this insulation to bound the amount of water that may cling to the inner and outer surfaces of the insulation. 


\subsubsection{Scrubber}

The scrubber is not expected to contain more than a token amount of fissile material under normal operating conditions. The scrubber tank is modeled as a cylinder of feed solution with a radius of $7.85876 \mathrm{~cm}$ and a height of $96.52 \mathrm{~cm}$ on top of a $25.4 \mathrm{~cm}$ (10 in.) tall cylinder of plutonium precipitate. The solution is $140 \mathrm{~g} \mathrm{Pu} / \ell$ plutonium nitrate with water. The solution portion of the scrubber model has a volume of $18.7 \ell$, which contains $2,622 \mathrm{~g}$ of plutonium when filled with feed solution. The solids are plutonium oxide $\left(2 \mathrm{~g} \mathrm{Pu} / \mathrm{cm}^{3}\right)$ with the void space filled with the plutonium nitrate feed solution. The solids portion of the scrubber has a volume of $4,928 \mathrm{~cm}^{3}$, and contains $9,886 \mathrm{~g}$ of plutonium. The actual scrubber has cooling tubes that will reduce the volume available for liquids and solids. Steel plates are located at the top and bottom of the scrubber column. The Pyrex ${ }^{\mathrm{TM}}$ glass is conservatively neglected and modeled as a void in the MCNP model.

\subsubsection{Scrubber waste tanks}

There are two scrubber waste tanks that have a combined volume of $46.85 \ell$. These tanks are $122.92 \mathrm{~cm}$ long, and are made of Pyrex ${ }^{\mathrm{MM}}$ glass with an inside radius of $7.82 \mathrm{~cm}$ and an outside radius of $8.32 \mathrm{~cm}$. In the model these tanks are filled with the $140 \mathrm{~g} \mathrm{Pu} / \mathrm{l}$ feed solution, containing a total of $6,558 \mathrm{~g}$ of plutonium. These Pyrex ${ }^{\mathrm{TM}}$ glass tanks are conservatively modeled without ${ }^{10} \mathrm{~B}$.

\subsubsection{Product receiver}

The product receiver is attached to the bottom end of the product collection tube below the calciner. The product receiver is modeled as a $15.716 \mathrm{~cm}$ tall glass cylinder with an outside radius of $4.921 \mathrm{~cm}$ and an inside radius of $4.445 \mathrm{~cm}$, with a metal flange on top. The product receiver has an internal volume of $0.948 \mathrm{\ell}$ and is filled with dry plutonium oxide at $5.5 \mathrm{~g} \mathrm{Pu} / \mathrm{cm}^{3}$, for a total of $5,216 \mathrm{~g}$ of plutonium.

A $0.9525 \mathrm{~cm}$ thick cylindrical pile of plutonium oxide the diameter of the product receiver is included in the model below the product receiver vessel to represent spilled material. This pile contains $955 \mathrm{~g}$ of plutonium.

\subsubsection{Load out container}

There are two load out containers in the model in the standard front and back load out positions on the load out tray. The load out container is a 1 pound slip can, represented as a steel cylinder 8.89 $\mathrm{cm}$ in height with an inner radius of $4.445 \mathrm{~cm}$ and an outer radius of $4.495 \mathrm{~cm}$. The load out containers are filled with plutonium oxide powder at $5.5 \mathrm{~g} \mathrm{Pu} / \mathrm{cm}^{3}$. Both containers combined (each $0.55 \mathrm{l}$ ) have a volume of $1.1 \mathrm{\ell}$ and a mass total of $6,070 \mathrm{~g}$ of plutonium. 


\subsubsection{Other Containers}

Three additional $0.5 \ell$ containers, one a sweeps container with $<100 \mathrm{~g} \mathrm{Pu}$ and an $\mathrm{H} / \mathrm{x} \leq 20$, twenty $30 \mathrm{~m} \ell$ sample vials, and maintenance fluid containers of up to $750 \mathrm{~m} \ell$ are not explicitly covered in the base case. However, they are covered by the overly conservative modeling of fissile material in the feed tank and scrubber system.

\subsubsection{Entire System}

The MCNP base case described above (case inpgc), has a calculated $\mathrm{k}_{\text {eff }}$ of $0.8776 \pm 0.0010$. This will be referred to as the MCNP base case. To determine whether the $2.54 \mathrm{~cm}(1 \mathrm{in}$.) of water reflection around each container would act to isolate containers of fissile material, a second calculation was performed. When the $2.54 \mathrm{~cm}\left(1 \mathrm{in}\right.$.) of water is removed, $\mathrm{k}_{\text {eff }}$ drops to $0.7516 \pm 0.0018$ (case inpgcno). Table 8 summarizes the MCNP calculations for the base case and the contingencies that are discussed in Section 5.3.

\begin{tabular}{|l|c|c|c||}
\hline \multicolumn{4}{|c|}{ Table 8. Calculated Results Using Base Case } \\
\hline \multicolumn{1}{|c|}{ Case } & Input file & kcalc & o \\
\hline $\begin{array}{l}\text { Base case that includes } 2.54 \mathrm{~cm} \\
(1 \mathrm{in} \text {.) water around all containers }\end{array}$ & inpgc & 0.8776 & 0.0010 \\
\hline $\begin{array}{l}\text { Base case without } 2.54 \mathrm{~cm}(1 \mathrm{in} .) \\
\text { water around all containers }\end{array}$ & inpgeno & 0.7517 & 0.0018 \\
\hline $\begin{array}{l}\text { Base case with three } 4.2 \mathrm{\ell} \\
\text { polybottles filled with } 140 \mathrm{~g} \mathrm{Pu} / \ell \\
\text { solution against outside of } \\
\text { glovebox added }\end{array}$ & inpgc3p & 0.8778 & 0.0009 \\
\hline $\begin{array}{l}\text { Base case with three } 3 \mathrm{\ell} \\
\text { polybottles filled with } 450 \mathrm{~g} \mathrm{Pu} / \ell \\
\text { solution against outside of } \\
\text { glovebox added }\end{array}$ & inpgc3p450 & 0.8789 & 0.0015 \\
\hline $\begin{array}{l}\text { Base case with all calcine } \\
\left(5.5 \mathrm{~g} \mathrm{Pu} / \mathrm{cm}^{3}\right) \text { saturated with } \\
\text { water }\end{array}$ & inpge & 0.9088 & 0.0014 \\
\hline $\begin{array}{l}\text { Base case with } 6.0 \mathrm{~g} \text { Pu/cm } \\
\text { calcine saturated with water }\end{array}$ & inpgd & 0.9337 & 0.0015 \\
\hline
\end{tabular}




\subsection{CONTINGENCY ANALYSIS}

\subsubsection{Plutonium Oxide in Wrong Area of Calciner}

The denitrating calciner normally operates to produce and have the calcine in the annular region at the bottom of the calciner. Calcine could be projected into the upper sections of the calciner by excess air or aqueous feed flow into the hot calciner bed or if the outlet is closed and calcine is still being made. The analyzed previous base case model described in Section 5.1 of this CSER has the calciner filled with dry, maximum density calcine of $5.0 \mathrm{~g} \mathrm{Pu} / \mathrm{cm}^{3}$. Because calcine may get to parts of the calciner other than the annular region, the previous base case model fills the entire calciner with calcine. This is bounding for calcine density up to $5.0 \mathrm{~g} \mathrm{Pu} / \mathrm{cm}^{3}$ because there is no more space to be filled, even in a contingency. This is the maximum expected density of calcine from normal operations. Section 4.11 of CSER 95-005 (Geiger 1995a) found the $\mathrm{k}_{\text {eff }}$ for the conservative previous base case model described in Section 5.1 of this CSER to be $0.815 \pm 0.003$.

Addendum I to CSER 95-005 (Geiger 1995b) concludes in Section 6.0 that the calciner is within allowable when full of $5.5 \mathrm{~g} \mathrm{Pu} / \mathrm{cm}^{3}$. This model bounds the case of the $4.5 \mathrm{~kg}$ of calcine being displaced from the geometrically favorable annular volume at the bottom of the calciner to the less favorable volume above the dome. Section 5.3 .13 of this CSER presents the analysis that even higher calcine densities are within allowables when the mass in the calciner is no more than $6 \mathrm{~kg}$, as it is for the calciner during nitric acid feed only testing. This model bounds both the expected abnormal cases and contingency cases with $a \mathrm{k}_{\text {eff }}$ that is within the allowable of 0.935 . The MCNP base case $\left(\mathrm{k}_{\text {eff }}=0.8776\right)$ has $5.5 \mathrm{~g} \mathrm{Pu} / \mathrm{cm}^{3}$ filling the calciner and therefore bounds for this density. Thus the case of calcine filling or being displaced in the calciner is double contingent.

\subsubsection{Plutonium Nitrate Added Instead of Nitric Acid}

In the expected operation, $\mathrm{HNO}_{3}$ is the feed to the $\mathrm{PuO}_{2}$ calcine bed. The $\mathrm{PuO}_{2}$ will not be dissolved in nitric acid alone (Compton 1999d). If plutonium nitrate is mistakenly used as feed instead of $\mathrm{HNO}_{3}$, two things are different, one is that the plutonium is already dissolved into the plutonium nitrate, and the other is that the plutonium inventory has been increased.

The 4L feed jug containing plutonium solution at the maximum allowed concentration of $450 \mathrm{~g} \mathrm{Pu} / \mathrm{l}$ would contain a maximum of $1.8 \mathrm{~kg} \mathrm{Pu}$, for a total of $1.8 \mathrm{~kg} \mathrm{Pu}+4.5 \mathrm{~kg} \mathrm{Pu}=6.3 \mathrm{~kg} \mathrm{Pu}$ in the calciner. There are three MONK6B cases that are relevant from Addendum 1 of CSER-95-005 (Geiger 1995b) shown in Table 9 below that have a larger plutonium inventory than this because the $11 \ell$ calciner is filled with $5.5 \mathrm{~g} \mathrm{Pu} / \mathrm{cm}^{3}$ calcine. 
HNF-3908 Rev. 0

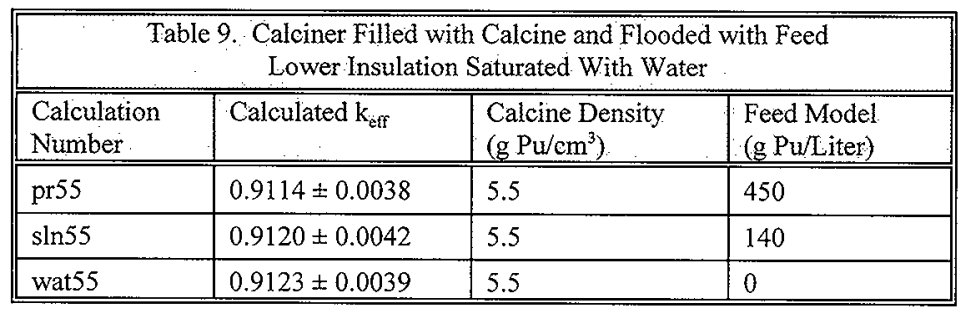

The MCNP base case was modified by replacing all of the interstitial void space in the dry calcine with water. This case (case inpge) thus had the calciner, downcomer, product receiver, and load out cans filled with this "mud" at a plutonium density of $5.5 \mathrm{~g} \mathrm{Pu} / \mathrm{cm}^{3}$ and had a $\mathrm{k}_{\text {eff }}$ of $0.9088 \pm 0.0014$. With over $38 \mathrm{~kg}$ of plutonium in the calciner alone, this case bounds any plutonium nitrate or nitric acid addition to the calciner.

These cases demonstrate that, even with the calciner filled with $\mathrm{PuO}_{2}$, and saturated with $450 \mathrm{~g} / \mathrm{l}$ Pu feed, $140 \mathrm{~g} \mathrm{Pu} / \mathrm{l}$ feed, or nitric acid feed (water), the feed Pu concentration does not cause the calculated $\mathrm{k}_{\text {eff }}$ to exceed the 0.935 allowable for the MONK calculations and 0.942 for the MCNP runs. The glovebox is double contingent for introduction of plutonium solution as feed to the calciner.

\subsubsection{Oxide Spill}

The MCNP base case includes a product receiver container and two slip lid $0.5 \ell$ containers filled with $\mathrm{PuO}_{2}$, which bounds a spill for nitric acid feed operation. The calculation in CSER 95 005 (Geiger 1995a) assumed that the entire load-out tray is filled with 1-pound cans full of calcine (more than 10 cans) at a normal product density of $5 \mathrm{~g} \mathrm{Pu} / \mathrm{cm}^{3}$ for the MONK6B calculations. For purposes of modeling, only the two cans placed in the load-out can spots were completely modeled. Then in addition to the two cans, the entire tray was covered with a right (non-circular) cylinder of dry calcine to a depth of $10 \mathrm{~cm}$. (This depth was chosen because it is deeper than the 1 pound can used for loadout, approximately $4 \mathrm{in}$.). The rest of the glovebox has the same configuration as in the standard model. The MONK6B plutonium model yielded a calculated $\mathrm{k}_{\text {eff }}$ of 0.87 , as shown in Table 1 , item \#3, Load out Over Batch, in CSER 95-005 (Geiger 1995a).

The MONK6B model also includes $1 \mathrm{~cm}(3 / 8$ in.) of calcine under the load out tray and $5 \mathrm{~cm}$ (2 in.) of water on the floor under the tray. The amount of calcine modeled on the tray would be many times the $4.5 \mathrm{~kg}$ allowed in the calciner and glovebox for the nitric acid feed test. This model is very conservative by mass, but only uses $5.0 \mathrm{~g} \mathrm{Pu} / \mathrm{cm}^{3}$, the maximum normal density expected, not the $5.5 \mathrm{~g}$ $\mathrm{Pu} / \mathrm{cm}^{3}$ that is the density limit. The conservatism in mass and reflection compensates for the nonconservatism of density. Also, Figure III.A.9(100)-5 in ARH-600 (Carter 1968) shows the minimum critical mass for the plutonium oxide density range of 5.0 to $5.5 \mathrm{~g} \mathrm{Pu} / \mathrm{cm}^{3}$ is constant. Using $5.0 \mathrm{~g}$ $\mathrm{Pu} / \mathrm{cm}^{3}$ is equivalent to $5.5 \mathrm{~g} \mathrm{Pu} / \mathrm{cm}^{3}$ in calculations. The model shows that an oxide spill is safe. In addition, Section 5.3.7, Seismic Event, of this CSER shows that $4.5 \mathrm{~kg}$ of plutonium is within allowables when outside the calciner in the presence of water. 
A spill of calcine from the calciner would be dry for a one contingency case. Figure III.A.9 (100)-5 of ARH-600 (Carter 1968) shows that even fully reflected, $\mathrm{H} / \mathrm{Pu}=2,5.5 \mathrm{~g} \mathrm{Pu} / \mathrm{cm}^{3} \mathrm{PuO}_{2}$ sphere has a minimum critical mass of more than $12 \mathrm{~kg}$. An inventory of $4.5 \mathrm{~kg}$ in Glovebox $188-1$ is then less than 0.45 of the minimum critical mass. A spill of the calcine is within allowables and the glovebox is double contingent.

\subsubsection{Acid Spill}

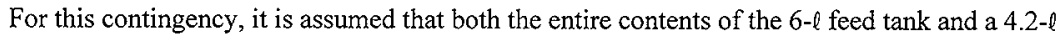
polybottle spill onto the intermediate floor of the glovebox. Sufficient liquid flows into the load-out containers to displace all the air, and the rest of the liquid flows onto the bottom floor of the glovebox. The two load-out containers are assumed to have been filled with calcine, so that the addition of liquid produces mud. For wet calcine, Figure III.A.9(100)-5 in ARH-600 (Carter 1968) shows that in the range of 5.0 to $5.5 \mathrm{~g} \mathrm{Pu} / \mathrm{cm}^{3}$, the minimum critical mass is insensitive to changes in plutonium density. An analysis at $5.0 \mathrm{~g} \mathrm{Pu} / \mathrm{cm}^{3}$ is representative of results at $5.5 \mathrm{~g} \mathrm{Pu} / \mathrm{cm}^{3}$.

5.3.4.1 Falling Solution. Initially, the solution will be draining from the intermediate floor of the glovebox, and therefore will be distributed through the air. For this analysis, a case was analyzed using MONK6B in CSER 95-005 where the solution is assumed to be above the load-out tray and partially surrounding the load-out cans; except for this change, the configuration is the same as in the standard model. The MONK model (DeNO3a2) yielded a calculated $\mathrm{k}_{\text {eff }}$ of 0.87 . This value is acceptably low to ensure subcriticality during this portion of the accident. Table 10 shows the results of the MONK analysis for acid spill scenarios.

\begin{tabular}{|l|l|l|l||}
\hline \multicolumn{4}{|c|}{ Table 10. MONK6B Contingency Analysis Results } \\
\hline \hline Contingency & $\begin{array}{l}\text { Computer Code } \\
\text { Run Number }\end{array}$ & $\begin{array}{l}\text { Discussion } \\
\text { Section }\end{array}$ & Calculated $\mathrm{k}_{\text {eff }}$ \\
\hline \multirow{2}{*}{ 2, Feed Tank and Polybottle Spill } & DeNO3a2 & 5.3 .4 .1 & $0.8688 \pm 0.0039$ \\
\cline { 2 - 5 } & DeNO3A2 & 5.3 .4 .2 & $0.8666 \pm 0.0039$ \\
\cline { 2 - 5 } & DeNO3AT & 5.3 .4 .3 & $0.8660 \pm 0.0039$ \\
\hline
\end{tabular}

5.3.4.2 Spilled Mud. The force of the falling liquid can be expected to move the powder around, potentially causing a less favorable geometry. In the analysis in CSER 95-005, the powder from the cans is assumed to be added to the powder from the floor of the load-out tray, and distributed in a right cone on top of the maximum allowed layer of wet powder ("mud") on the bottom of the glovebox. The water covering the mud (limited to $5.1 \mathrm{~cm}$ [2 in.] above the bottom of the glovebox by the criticality drain) is replaced with feed solution in the vicinity of the cone of mud. For ease of analysis, the load out tray is also removed. Except for these changes, the configuration is the same as in the standard model. The MONK model (DeNO3A2) yielded a calculated $k_{\text {eff }}$ of 0.87 as shown in Table 10. Thus, after the spilled feed solution has washed the calcine to the floor, the system is still acceptably subcritical and within the allowable value of 0.935 . 
5.3.4.3 Lower Density Mud. In addition to moving the calcine around, the liquid may also reduce its density. In the CSER 95-005 analysis, the powder is assumed to distribute as above, but have a lowered density of $3 \mathrm{~g} / \mathrm{cm}^{3}$ of plutonium. The rest of the glovebox configuration remains the same. The MONK model (DeNO3AT) yielded a calculated $\mathrm{k}_{\text {eff }}$ of 0.87 as shown in Table 10. Thus, the system will remain acceptably sub-critical in case of a feed solution spill. The seismic Section, 5.3 .6 , shows that at even lower densities, the $4.5 \mathrm{~kg}$ plutonium inventory is within allowables and is double contingent.

5.3.4.4 Wet Lower Insulation. The contingency where a spill of feed solution onto the absorbent insulation around the lower calciner section has been addressed in Addendum 1 of CSER 95-005 (Geiger 1995b). For this contingency, an entire $3 \mathrm{l}$ bottle of plutonium nitrate solution is assumed to have spilled into the absorbent insulation. The solution is modeled with a plutonium concentration of $450 \mathrm{~g} / \mathrm{l}$, an isotopic composition of $96.4 \mathrm{w} / \mathrm{o}{ }^{239} \mathrm{Pu}, 3 \mathrm{w} / \mathrm{o}{ }^{240} \mathrm{Pu}$, and $0.6 \mathrm{w} / \mathrm{o}{ }^{241} \mathrm{Pu}$, and a nitric acid concentration of $1 \mathrm{M}$. Four configurations of spilled solution were modeled:

The PR solution saturating an annular shell against the inner surface of the insulation, with water saturating the remainder of the insulation;

The PR solution saturating a slab against the top surface of the insulation, with water saturating the remainder of the insulation;

The Pr solution saturating the outer "half" of a torus (vertical cross section a semicircle) with the inner cylindrical surface coinciding with the inner surface of the insulation at the top, with water saturating the remaining insulation;

A homogeneous mixture of water and some spilled PR solution saturating the entire volume of the insulation.

Table 11 copied from Table 5.1 in Addendum 1 of CSER 95-005 (Geiger 1995b) presents the results of the calculations for these geometries, for a calciner full of dry calcine. For a calcine density of $6.5 \mathrm{~g} \mathrm{Pu} / \mathrm{cm}^{3}$, each of the four configurations yielded a $\mathrm{k}_{\text {eff }}$ of less than 0.935 and therefore satisfies criticality safety limits. 
HNF-3908 Rev. 0

\begin{tabular}{|c|c|c|}
\hline \multicolumn{3}{|c|}{$\begin{array}{l}\text { Table I } 1 \text { Addendum } 1 \text { of CSER } 95005 \\
\text { Contingency A alysis for a Feed Spill }\end{array}$} \\
\hline $\begin{array}{l}\text { Calculation } \\
\text { Number }\end{array}$ & Calculated $\mathrm{k}_{\mathrm{ft}}$ & $\begin{array}{l}\text { Calcine Density } \\
\left(\mathrm{g} \mathrm{Pu} / \mathrm{cm}^{3}\right)\end{array}$ \\
\hline shell $65^{2}$ & $0.8562 \pm 0.0046$ & 6.5 \\
\hline shell1170 & $0.8919 \pm 0.0041$ & 7 \\
\hline slab65 & $0.8496 \pm 0.0040$ & 6.5 \\
\hline slab70 3 & $0.8795 \pm 0.0041$ & 7 \\
\hline tor $65^{4}$ & $0.8595 \pm 0.0043$ & 6.5 \\
\hline tor $70^{4}$ & $0.8987 \pm 0.0041$ & 7 \\
\hline dil $65^{5}$ & $0.9328 \pm 0.0042$ & 6.5 \\
\hline $\operatorname{dil1} 170^{5}$ & $0.9483 \pm 0.0044$ & 7 \\
\hline
\end{tabular}

${ }^{1}$ The total spilled volume is $3.15 \ell$, and the total insulation interstitial volume is 16.88 l.

${ }^{2}$ shell65, shell 70 : The feed is distributed in a cylindrical shell bounded on the inside by the inside surface of the insulation.

${ }^{3}$ slab65, slab70: The feed is distributed in an annular disk bounded on the top by the top surface of the insulation.

${ }^{4}$ tor 65 , tor 70: The feed is distributed in a splint torus (rotated semicircle) with the flat surface of the semicircle against the inside surface of the insulation and the top of the torus touching the top of the simulation.

5dil65, dil70: The feed is diluted with sufficient water to just saturate the insulation and distributed throughout the insulation.

The MCNP base case (case inpge) included water saturated insulation on the lower section of the calciner. In addition, it had $2.54 \mathrm{~cm}(1 \mathrm{in}$.) of water surrounding the calciner and all other containers and vessels.

5.3.4.5 Spilled Acid Conclusion. The actual initial conditions for an acid spill are that the $4.5 \mathrm{~kg}$ of dry $\mathrm{PuO}_{2}$ is in the calciner and about $30 \mathrm{~g}$ is outside. The above analysis is for much larger amounts of $\mathrm{PuO}_{2}$ mass outside the calciner and plutonium solution, $140 \mathrm{~g} \mathrm{Pu} / \mathrm{l}$, rather than just nitric acid solutions. The above results show that operations of the calciner for the nitric acid feed test are double contingent for an acid spill, since for the actual conditions there would only be about $6 \%$ of a minimum critical mass $(30 \mathrm{~g} \mathrm{Pu}) /(530 \mathrm{~g} \mathrm{Pu})$. 


\subsubsection{Plutonium in Scrubber System}

The scrubber system is considered to be composed of:

- The scrubber, a 6 inch diameter, $117.76 \mathrm{~cm}$ (46 5/8 in.) high Pyrex ${ }^{\mathrm{TM}}$ glass pipe used as approximately a $20 \ell$ tank,

- The scrub solution catch tanks, two 22 l tanks receiving spent scrub solution,

- A chilled water supply with a 5 gallon capacity, and

- A vacuum trap that connects to the plant process vacuum system.

The scrub solution is pumped into the scrubber through the scrub solution pump from a scrub solution reservoir and, because of location, geometry, and incredibility of back flow against a pump head and gravity, is not considered in this criticality analysis.

5.3.5.1 Scrubber. The scrubber system is not expected to contain more than a token amount of fissile material (less than $0.01 \mathrm{~g} \mathrm{Pu} / \mathrm{cm}^{3}$ of solution) under normal operating conditions. The silicon carbide filters in the calciner should prevent significant fissile contamination in the scrubber. Human observation provides manual system shutoff upon failure of a filter.

During off-normal conditions of calciner heating loss and filter failure, precipitation could occur and solids could accumulate in the scrubber. A concentration of $1 \mathrm{~g} \mathrm{Pu} / \mathrm{cm}^{3}$ would be noticeable through the clear borosilicate glass. A concentration of $2 \mathrm{~g} \mathrm{Pu} / \mathrm{cm}^{3}$ is very apparent and would be easily detected by the operator.

The standard model (case DeNO3as in Geiger 1995a) included 33 in. thickness of $140 \mathrm{~g} \mathrm{Pu} / \mathrm{l}$ $\mathrm{Pu}\left(\mathrm{NO}_{3}\right)_{4}$ solution on top of a $25.4 \mathrm{~cm}\left(10 \mathrm{in}\right.$.) thickness of $2 \mathrm{~g} \mathrm{Pu} / \mathrm{cm}^{3}$ precipitate in the scrubber. The $140 \mathrm{~g} \mathrm{Pu} / \mathrm{l}$ layer contains a modeled mass of $1.72 \mathrm{~kg} \mathrm{Pu}$. The $2 \mathrm{~g} \mathrm{Pu} / \mathrm{cm}^{3}$ precipitate $25.4 \mathrm{~cm}$ (10 in.) layer contains a modeled mass of $7.39 \mathrm{~kg}$ Pu. This totals to a modeled mass of $9.11 \mathrm{~kg}$ Pu in the scrubber. The standard plutonium model had $k_{\text {eff }}=0.8151 \pm 0.003$ (page 12 in Geiger 1995a).

The MCNP calciner model, inpgc, has $2.6 \mathrm{~kg} \mathrm{Pu}$ in the scrubber solution, $9.8 \mathrm{~kg} \mathrm{Pu}$ in the scrubber solids, $3.28 \mathrm{~kg} \mathrm{Pu}$ in each of the spent scrubber solution storage tanks and had $\mathrm{k}_{\text {eff }}=0.8776 \pm 0.0010$.

The unlikely nature of large amounts of precipitates accumulating within the scrubber along with the demonstrated safety of such an accumulation suggests that the usage of a $25.4 \mathrm{~cm}(10 \mathrm{in}$.) layer of $2.0 \mathrm{~g} \mathrm{Pu} / \mathrm{cm}^{3}$ for the plutonium precipitate is acceptable. A scrubber solution overbatch, doubling the precipitate height for the feed and scrubber tanks to $50.8 \mathrm{~cm}$ (20 in.), (case DeNO3a7 in Geiger 1995a) had $\mathrm{k}_{\mathrm{eff}}=0.8295 \pm 0.0037$. Thus the $25.4 \mathrm{~cm}$ precipitate height can be used as a criticality limit for operations. The $25.4 \mathrm{~cm}$ (10 in.) height limit for solids in the scrubber tank satisfies the double contingency criterion.

5.3.5.2 Scrub Solution Catch Tanks. The standard model (case DeNO3as in Geiger 1995a) also included the waste scrub solution storage tanks with a conservative 23.4 liter nominal volume filled with a $140 \mathrm{~g} \mathrm{Pu} / \mathrm{l}$ feed $\mathrm{Pu}\left(\mathrm{NO}_{3}\right)_{4}$ solution. This models each storage tank containing a total of $3.28 \mathrm{~kg}$ of Pu. Comparing the $7.39 \mathrm{~kg}$ Pu precipitate volume to the $3.28 \mathrm{~kg}$ Pu per tank demonstrates just how much extra material is added to the overall system by the $25.4 \mathrm{~cm}$ (10 in.) precipitate layer in 
the scrubber assumption. All of these cases satisfied the criticality safety criteria. The standard plutonium model, with feed solution in the spent scrub solution storage tanks, had $\mathrm{k}_{\text {eff }}=0.8151 \pm 0.003$ (page 12 in Geiger 1995a).

The MCNP calciner model, inpgc, has $2.6 \mathrm{~kg} \mathrm{Pu}$ in the scrubber solution, $9.8 \mathrm{~kg} \mathrm{Pu}$ in the scrubber solids, $3.28 \mathrm{~kg}$ Pu in each of the spent scrubber solution storage tanks and had $\mathrm{k}_{\text {eff }}=0.8776 \pm 0.0010$. Thus showing that even if plutonium feed solution also got in the scrub over flow tanks, the glovebox is double contingent.

5.3.5.3 Scrubber Chilled Water Supply. The scrubber tank is cooled by cooling coils. The cooling coils are cooled by water from a 5 gallon reservoir of chilled water that is located in an adjacent room, Room 187 . The 5 gallon reservoir is potentially a non-favorable geometry for criticality safety. However, that the scrubber tank would have more than trace amounts of plutonium is unlikely because the contamination is so easily detected. The pressure head from cooling coils to scrubber tank prevents flow to the unfavorable geometry tank.

The coolant inside the coils in the scrubber is at a higher pressure than atmospheric pressure, because this coolant must be pumped from another room and returned to that room. The scrubber drains to the two $22 \ell$ spent scrub solution tanks that are connected to the plant process vacuum system. The scrubber tank is at a pressure lower than the coolant coil liquid, causing any leak in the coolant system coils to drain the coolant system into the scrubber, and not vice versa. The transfer lines bringing the coolant water to the scrubber, enter Glovebox 188-1 at a level higher than the scrubber, again causing a higher hydraulic head for the coolant water supply that would drain into the scrubber and not the scrubber solution toward the unfavorable geometry cooling water reservoir. incredible.

The contamination of the cooling water supply with solution from the scrubber is considered

5.3.5.4 Spent Scrub Solution Vacuum Trap. The two $22 \ell$ spent scrub solution storage tanks are connected through a vacuum trap to the PFP $234-5 Z$ plant $26 \mathrm{in}$. $\mathrm{Hg}$ process vacuum system. The 234-5Z plant process vacuum system is covered by CPS-Z-165-80141. This criticality protection specification is supported by CSAR 78-013, CSAR 78-013 Addendum 1, CSAR 78-013 Addendum 2, and CSER 94-011. The vacuum trap operation is described in Section 2.1.5.4. The plant vacuum system is double contingent for fissile solutions and shuts off the vacuum. The scrub solution vacuum trap is redundant.

According to the technical assessment of the PFP vertical direct denitration calciner (Merrick and Rickords 1996), no credible failure modes are evident for this piece of equipment.

The small $7.62 \mathrm{~cm}(3 \mathrm{in}$.) diameter, and the small volume $\approx 0.7 \ell$, both preclude any criticality concern in this piece of equipment. The vacuum trap is double contingent. 


\subsubsection{Seismic Event}

If, during the seismic event, the vertical calciner downcomer falls out and the stirrer keeps turning, the calciner could easily release up to $100 \%$ of the fissile material contained within. This material will then be free to combine with the rest of the plutonium oxide in the glovebox. In reality, some release fraction less than $100 \%$ would be expected, with the balance remaining in the calciner and separated from fissile material outside. It is also realistic that some plutonium oxide powder would cover the floor and sides of the glovebox, resulting in a higher-leakage, lower-reactivity geometry. However, unless the distribution of fissile material is known, controlled, or can be predicted based upon physical arguments, it is conservative to assume all $4.5 \mathrm{~kg}$ of plutonium comes together into a compact spherical geometry, fully reflected with water. For this analysis, full reflection means $25 \mathrm{~cm}$ of water. The current inventories of materials present in glovebox 188-1 are:

Available moderator: $5.2 \ell$ in the form of $\mathrm{HNO}_{3}$ in the feed tank $750 \mathrm{~m} \ell$ in the form of maintenance fluids scrubber tanks of solution (water $+\mathrm{NaOH}$ )

Fissile material: $\quad 4.05 \mathrm{~kg}$ Pu in the form of $\mathrm{PuO}_{2}$ in the lower calciner $14 \mathrm{~g}$ Pu in one polyjar $14 \mathrm{~g}$ Pu holdup assumed in the glovebox (dust covering walls, etc.) (Seismic base case conservatively assumes $4.5 \mathrm{~kg} \mathrm{Pu}$ in glovebox)

The plutonium is in oxide form, $\mathrm{PuO}_{2}$, and is analyzed at densities between 0.45 to $5.0 \mathrm{~g} \mathrm{PuO}_{2} / \mathrm{cm}^{3}$. The minimum density for plutonium oxide powder given in the SAR (Section 9.2.4.2.11 in $\mathrm{FDH} 1999$ ) is $2.0 \mathrm{~g} \mathrm{PuO}_{2} / \mathrm{cm}^{3}$, and this value is also given by Carter (1980). According to electronic-mail communication from J. A. Compton (Compton 1999a), his estimate for a conservatively-low density for $\mathrm{PuO}_{2}$ powder from the calciner is $2.75 \mathrm{~g} \mathrm{PuO}_{2} / \mathrm{cm}^{3}$, with $2.5 \mathrm{~g} \mathrm{PuO}_{2} / \mathrm{cm}^{3}$ being a "totally 'audit-proof" [density], given the process we're using, the temperature of the bed where the feed is entering, and the speed of conversion in a bed that hot." This is consistent with the value used in the SAR, and is more than twice the bulk density required to assure criticality safety as shown in Table 12, even if all of the $\mathrm{PuO}_{2}$ exits the calciner and combines with the rest of the fissile material in the glovebox (up to the $4.5 \mathrm{~kg}$ Pu inventory), and forms a fully-reflected sphere, with full moderator penetration of the interstitial voids within the bulk powder. The results show the glovebox is double contingent in a seismic event.

The theoretical density of $\mathrm{PuO}_{2}$ is $11.46 \mathrm{~g} \mathrm{PuO}_{2} / \mathrm{cm}^{3}$. For powder density of $2.0 \mathrm{~g} \mathrm{PuO}_{2} / \mathrm{cm}^{3}$, this implies a packing fraction of $2.0 / 11.46=0.17$. The remainder of this volume is assumed to be interstitial space available for water penetration. With water filling these voids, the result is treated as a homogeneous $\mathrm{PuO}_{2}-\mathrm{H}_{2} \mathrm{O}$ mixture. Table 12 contains the results for oxide densities of between 0.45 and $5.0 \mathrm{~g} \mathrm{PuO}_{2} / \mathrm{cm}^{3}$; Figure 4 shows these results graphically. Plutonium isotopics are conservatively assumed to be $96 \mathrm{wt} \%{ }^{239} \mathrm{Pu}, 3 \mathrm{wt} \%{ }^{240} \mathrm{Pu}$, and $1 \mathrm{wt} \%{ }^{241} \mathrm{Pu}$. 
HNF-3908 Rev. 0

\begin{tabular}{|c|c|c|c|c|c|c|c|}
\hline $\begin{array}{l}\text { Pu Density } \\
\left(\mathrm{g} / \mathrm{cm}^{3}\right)\end{array}$ & $\begin{array}{c}\text { Oxide } \\
\text { Density } \\
\left(\mathrm{g} / \mathrm{cm}^{3}\right)\end{array}$ & $\begin{array}{l}\text { Mixture } \\
\text { Density } \\
\left(\mathrm{g} / \mathrm{cm}^{3}\right)\end{array}$ & $\begin{array}{l}\text { Moderator } \\
\text { Volume } \\
\text { (L) }\end{array}$ & $\begin{array}{l}\mathrm{H} / \mathrm{Pu} \\
\text { Ratio }\end{array}$ & $\begin{array}{l}\text { Sphere } \\
\text { Radius } \\
\text { (cm) }\end{array}$ & $\mathrm{k}_{\text {calc }}$ & $\sigma$ \\
\hline 4.410 & 5.00 & 5.564 & 0.575 & 3.4 & 6.245 & 0.7316 & 0.0028 \\
\hline 3.528 & 4.00 & 4.651 & 0.830 & 4.9 & 6.728 & 0.7436 & 0.0026 \\
\hline 2.646 & 3.00 & 3.738 & 1.256 & 7.4 & 7.405 & 0.7670 & 0.0027 \\
\hline 1.764 & 2.00 & 2.825 & 2.106 & 12.4 & 8.476 & 0.8111 & 0.0033 \\
\hline 0.882 & 1.00 & 1.913 & 4.657 & 27.5 & 10.68 & 0.9140 & 0.0032 \\
\hline 0.397 & 0.45 & 1.410 & 10.90 & 64.3 & 13.94 & 1.0581 & 0.0035 \\
\hline $0.397^{(1)}$ & 0.45 & 1.410 & 10.90 & 64.3 & 17.56 & 1.0335 & 0.0013 \\
\hline
\end{tabular}

(1) Note: This case was a higher-leakage hemisphere with the same Pu mass.

Figure 4. Effective Multiplication Factor, $\mathrm{k}_{\mathrm{eff}}$, vs. Plutonium Oxide Density. Fully Reflected Spherical Geometry - Water Penetrates All Void Space in Oxide.

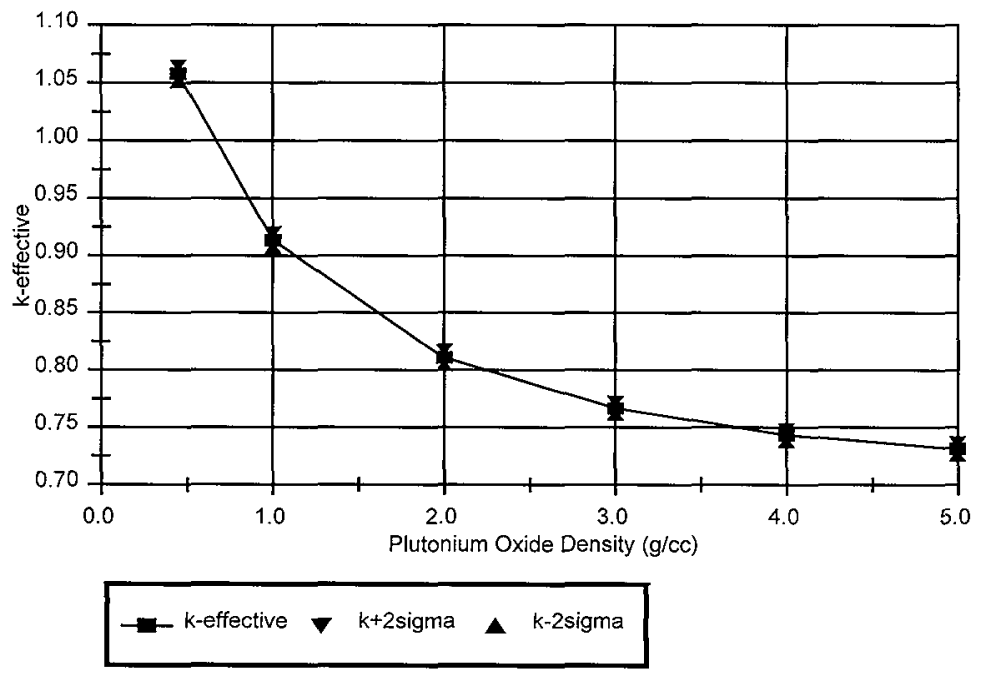

As long as the bulk oxide density remains above $1.0 \mathrm{~g} \mathrm{PuO}_{2} / \mathrm{cm}^{3}$, which is only half the expected (SAR) value, criticality safety in the seismic event can be assured ( $k_{\text {eff }}$ will be less than 0.914 and the allowable is 0.938 per Erickson 1998). The glovebox is double contingent for a seismic event when the plutonium mass is limited to $4.5 \mathrm{~kg}$ of high fired calcine. 
The following conservative assumptions were used to analyze the seismic event. An actual seismic event is expected to be less reactive than these conditions which would decrease the $k_{\text {eff. }}$

1. All of the plutonium inventory $(4.5 \mathrm{~kg} \mathrm{Pu})$ comes together into a compact sphere. This represents a $100 \%$ release fraction from the calciner.

2. Water penetration into the interstitial voids between the sand-like particles of $\mathrm{PuO}_{2}$ provides for a maximum credible amount of moderation.

3. The plutonium oxide region is fully reflected with water.

4. The $\mathrm{PuO}_{2} / \mathrm{H}_{2} \mathrm{O}$ mixture was modeled as a homogeneous mixture, taking no credit for any selfshielding associated with clumps of oxide, which would reduce $\mathrm{k}_{\text {eff. }}$ Realistically, a wellmixed, homogeneous slurry of plutonium oxide and water is not likely, as there is no significant energy source available to agitate or suspend the constituents.

Additional analysis was performed, with smaller release fractions of plutonium oxide from the calciner than $100 \%$. If one-fourth $(1125 \mathrm{~g})$ of the mass, or one-third $(1500 \mathrm{~g})$, is released and this material formed the same fully-reflected sphere, any $\mathrm{H} / \mathrm{Pu}$ ratio between 0 and 60 can be shown to be safe. The $\mathrm{H} / \mathrm{Pu}=60$ value is the highest value possible before the powder would become a solution where the $\mathrm{PuO}_{2}$ particles are completely surrounded by water. But this is not possible because the dense, insoluable plutonium oxide particles will fall out of the surrounding water under the influence of gravity. $\mathrm{H} / \mathrm{Pu}$ of 60 is the conservative upper bound on $\mathrm{H} / \mathrm{Pu}$ that needs to be considered in this analysis. The fissile material released from the calciner will not go into solution because it is insoluble, high-fired $\mathrm{PuO}_{2}$. Introduced nitric acid or water is not capable of dissolving it. The dense $\mathrm{PuO}_{2}$ particles would fall out of the water into a layer of $\mathrm{PuO}_{2}$ with water interstitial in it. Figure 4 shows that the curve of $2500 \mathrm{~g}$ Pu release mass is the largest mass that is within the conservative allowable of 0.94 for the H/Pu range of 0 to 60 . A mass of $2500 \mathrm{~g}$ Pu is a release of $56 \%$ of the $4.5 \mathrm{~kg}$ Pu allowed in the calciner. Figure 5 shows these results superimposed over those shown in Figure 4.

An upper limit for the Pu in oxide density is projected from calciner run data and theoretical analysis (Compton 1999b) to be around $5.5 \mathrm{~g} \mathrm{PuO}_{2} / \mathrm{cm}^{3}$, and this is why the analyzed density range was extended this far. However, as the oxide density increases beyond $2.0 \mathrm{~g} \mathrm{PuO}_{2} / \mathrm{cm}^{3}$ (or the $\mathrm{H} / \mathrm{Pu}$ ratio decreases below 10), there is clearly no danger of criticality from only $4500 \mathrm{~g}$ of plutonium; the $\mathrm{k}_{\text {eff }}$ curves indicate a downward trend with increasing $\mathrm{Pu}$ density (or decreasing $\mathrm{H} / \mathrm{Pu}$ ).

A plutonium oxide density of $2.0 \mathrm{~g} \mathrm{PuO}_{2} / \mathrm{cm}^{3}$ is equivalent to an $\mathrm{H} / \mathrm{Pu}$ atom ratio of 12.4 , and is therefore under moderated, but the physical form of the $\mathrm{PuO}_{2}$ will be sand-like particles that will not float in water. Complete water penetration into the interstitial voids in bulk powder of normal density was considered to be the most reactive credible configuration. Agitation, acting against gravity to induce a lower packing fraction, is not considered credible in static geometries. While it is true that the glovebox will not be "static" during the earthquake, these events last for only a short time; it will take time for the plutonium oxide to exit the calciner, once it is damaged by the earthquake. It will take more time for the powder to drain into and come into close proximity with the other fissile material in the glovebox. It is considered incredible to maintain an agitated configuration, where plutonium oxide particles are suspended against gravity, during the same earthquake that causes the damage which allows the material to come together. 
Figure 5. Effective Multiplication Factor, $\mathrm{k}_{\mathrm{eff}}$, vs. Hydrogen-to-Plutonium Atom Ratio. Fully Reflected Spherical Geometry - Water Penetrates All Void Space in Oxide.

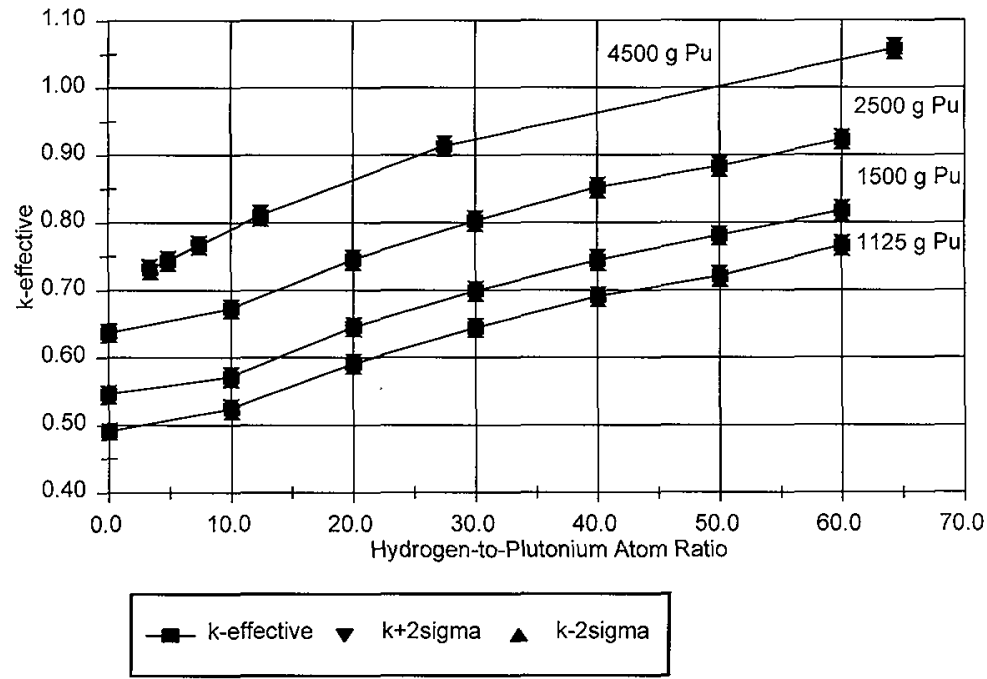

As for the end-state geometry, in all likelihood, a more realistic geometry would be a hemispherical pile, cone, slab, or some other higher-leakage geometry, which has a lower $k_{\text {eff }}$ for the same mass of fissile material.

It is therefore concluded that a criticality accident in Glovebox 188-1 is not credible as a result of a seismic event for an inventory of $4.5 \mathrm{~kg} \mathrm{Pu}$ in the form of high fired calcine, for only nitric acid as feed material, and for a seismically unqualified glovebox. The glovebox is then double contingent for a seismic event.

\subsubsection{Fire}

5.3.7.1 Water Ingress into Glovebox. In the event of a fire, the introduction of sprinkler and firefighting water is considered. According to Addendum 1 to CSER 95-005 (Geiger 1995b), the $\mathrm{k}_{\mathrm{eff}}$ for fire water entry is 0.912 , which is within the MONK6B allowable of 0.935 . The fire contingency was analyzed in Section 5.2 of Addendum 1 (Geiger 1995a). The model includes a calciner filled with $5.5 \mathrm{~g} \mathrm{Pu} / \mathrm{cm}^{3}$ calcine saturated with water, even though fire water would not have a way to enter the metal calciner. The lower insulation is modeled as saturated with water, although the insulation is covered by a metal skirt that would prevent water falling into the glovebox from wetting the insulation. 
The product containers, plutonium layer on the floor and water on the floor are included in the model as are the feed container, feed tank, and scrubber tanks. The water depth in the glovebox is limited to the $5.1 \mathrm{~cm}(2 \mathrm{in}$.) as modeled in the analysis by a criticality drain in the glovebox as shown in Section 5.3 .8 below. Table 5.2 in Section 5.2 of the Geiger reference also shows that the $\mathrm{k}_{\text {eff }}$ for the model only increases to 0.942 ( 0.007 above allowable), for the MONK analysis even if the calcine density increases to $6.0 \mathrm{~g} \mathrm{Pu} / \mathrm{cm}^{3}$, which is above the limit of $5.5 \mathrm{~g} \mathrm{Pu} / \mathrm{cm}^{3}$. For the MCNP calculation (case inpge), this contingency results in a $\mathrm{k}_{\mathrm{eff}}=0.9088 \pm 0.0014$ which is within the allowable of 0.942 . The MCNP analysis using $6.0 \mathrm{~g} \mathrm{Pu} / \mathrm{cm}^{3}$ flooded calcine gave a $\mathrm{k}_{\text {eff }}$ of $0.9337 \pm 0.0015$ (case inpgd), which is still within the allowable 0.942 . This gives assurance of a reasonable margin of safety on glovebox operations. Table 5.2 from Addendum 1 also shows that even if plutonium is entrained in the fire fighting water, the reactivity does not increase significantly. These results show that the calciner operation with acid feed is double contingent.

5.3.7.2 Fire Fighting Category. A solid stream of water could enter the glovebox, displace plutonium from the calciner, wet the lower calciner insulation, supply water faster than the criticality drain could drain it, displace rags to clog the criticality drain, and stir up the loose plutonium to a critical configuration. The use of solid streams of water to fight fires is rare because it is not a normal fire fighting method. To decrease the probability that a solid stream of water would be used in Room 188 for fire fighting, a criticality fire fighting category limit of $\mathrm{C}$ is specified for Room 188 . This limit supports the conclusion that the glovebox is double contingent for a fire for the acid testing of the calciner.

\subsubsection{Criticality Drain}

A study of PFP sprinklers (Hammelman 1974) did not find inflow rates to any PFP gloveboxes greater than $0.4 \mathrm{l} / \mathrm{s}$ (6 gpm) to be credible. A criticality drain study (Lehmkuhl 1974) demonstrated that even a water inflow rate of $0.4 \mathrm{l} / \mathrm{s}(6 \mathrm{gpm})$ will increase the water level by less than $0.64 \mathrm{~cm}$ (1/4 in.) above a 7.6-cm (3-in.) diameter bottom-mounted criticality drain. Therefore, the liquid level in the glovebox will not significantly exceed $5 \mathrm{~cm}$ ( 2 in.) if the criticality drain is operable.

Assuming the criticality drain plugs, and the glovebox fills completely with water (two contingencies), then the system is not acceptably subcritical as shown in Appendix D of CSER 95-005 (Geiger 1995a). Consequently, the criticality drain must be kept unobstructed to make a complete glovebox flood double contingent.

\subsubsection{Acid Fed Too Quickly}

The contingency of mixing nitric acid solution with the plutonium oxide within the calciner to form "mud" has been examined, and demonstrated to be safe by CSER 95-005 (Geiger 1995a) and CSER 95-005, Addendum 1 (Geiger 1995b). Scenarios where this mud formation could occur are: feeding a nitric acid solution into a cold calciner; feeding a nitric acid solution into the calciner too quickly; or pouring the nitric acid into the calciner through a pressure relief port. It has been demonstrated that the complete saturation of maximum density plutonium oxide with maximum concentration feed solution yielded the most reactive mud composition. In CSER 95-005, Addendum 1, the mud was made from a $5.5 \mathrm{~g} \mathrm{Pu} / \mathrm{cm}^{3}$ plutonium oxide mixed with either a $450 \mathrm{~g} \mathrm{Pu} / \ell$, 
a $140 \mathrm{~g}$ Pu/l solution, or water. Table 5.2 from CSER 95-005, Addendum 1 demonstrates that the maximum calculated $\mathrm{k}_{\text {eff }}$ for these scenarios was $0.912 \pm 0.004$, within the allowable of 0.935 . The MNCP model with $5.5 \mathrm{~g} \mathrm{Pu} / \mathrm{cm}^{3}$ calcine saturated with water had a calculated $\mathrm{k}_{\mathrm{eff}}$ of $0.9088 \pm 0.0014$ (case inpge) which is within the allowable of 0.942 . Further, Table 7 shows that there is statistically no difference when comparing the results for mixing the plutonium oxide with a plutonium nitrate solution or with water because most of the reactivity is due to the much denser calcine at $5.5 \mathrm{~g} \mathrm{Pu} / \mathrm{cm}^{3}$, rather than the added solution. All these cases using the $5.5 \mathrm{~g} \mathrm{Pu} / \mathrm{cm}^{3}$ (or less) density plutonium oxide was determined to satisfy the criticality safety limit, thus showing the glovebox to be double contingent.

\subsubsection{Second 4L Bottle of Acid in Glovebox}

The reactivity of bringing a second bottle of acid into the glovebox was modeled as an increase in reflection for calciner acid feed operation. In the original MONK code calculations (Geiger 1995a), this case was included in the $\mathrm{k}_{\text {eff }}=0.912$ calculation of Section 5.2.3. For the MCNP analysis, the base case included $2.54 \mathrm{~cm}$ ( 1 in.) of water reflection around every container and vessel for a $\mathrm{k}_{\mathrm{eff}}=0.8776$. The difference between these two calculations is due to the model differences, but both show that the double contingency requirement is met with calculated reactivities less than the targets of 0.935 and 0.942 for the MONK and MCNP codes, respectively.

\subsubsection{Plutonium-bearing Drum Brought into Room 188}

No plutonium is to be brought into Room 188-1 during the nitric acid feed operation. It is only an unlikely mistake that could cause plutonium to be brought into the room. In the original MONK calculations (Geiger 1995a), this case was covered by the great quantity of plutonium in the base case $\left(\mathrm{k}_{\mathrm{eff}}=0.815\right)$ that is larger and closer to the calciner than any other mass that could be brought into the room. In the new MCNP analysis, three $4.2 \ell$ containers of the greatest reactivity solution ( $140 \mathrm{~g} \mathrm{Pu} / \mathrm{l})$ were modeled with no spacing on three sides of the glovebox. The resultant $k_{\text {cff }}$ was $0.8778 \pm 0.0009$ (case inpgc $3 \mathrm{p}$ ), which is less than the 0.942 safe $\mathrm{k}_{\text {eff }}$ target. To show the effect on reactivity if the maximum $\mathrm{Pu}\left(\mathrm{NO}_{3}\right)_{4}$ concentration was in the containers, an MCNP calculation was performed with the resultant $k_{\text {eff }}$ of $0.8789 \pm 0.0015$ (case inpgc $3 p 450$ ). All of these calculations show that the double contingency requirement is met. These cases also cover removal of calcine from the calciner or glovebox in allowed containers because separating and removing material lowers the total reactivity of the glovebox.

\subsubsection{Dissolving Acid Placed in Feed Tank}

The expected operation of the vertical calciner involves pure $\mathrm{HNO}_{3}$ in the feed tank that is pumped into the calciner. The calciner is heated before feed solution is allowed in, and the scrubber will condense the resulting vapors for collection in the spent scrubber solution tanks. The $\mathrm{PuO}_{2}$ in the calciner is not expected to dissolve if pure $\mathrm{HNO}_{3}$ is used in the feed tank (Compton 1999d).

The off-normal, unlikely condition is that another acid that could dissolve $\mathrm{PuO}_{2}$ could be placed in the feed tank. The acid can only pose a criticality threat if it gets into the calciner as a liquid. For 
this to happen a second unlikely error would have to be made. The acid would have to be poured into the calciner or the interlock fail and allow feed into a cold calciner. Because two unlikely errors would have to be made before this contingency could happen it is considered incredible. If this incredible event occurred, the dissolution, occurring in the calciner, would have the most likely result of being calcined back into $\mathrm{PuO}_{2}$ again. In the transitional state of $\mathrm{PuO}_{2}$ being dissolved and with greater moderation, then the $5.2 \ell$ of feed tank solution volume is insufficient to cause $4.5 \mathrm{~kg}$ Pu to become critical, even in spherical geometry and with full water reflection, as indicated in Section 5.3.6 on seismic analysis and on Figure III.A.9(100)-4 in ARH-600 (Carter 1968). The calciner could be filled by repeatedly filling the feed tank with dissolving acid. The calciner is 6 in. schedule 10 pipe which has an inside diameter of less than 6.5 in. and an outside diameter of 6.625 in. Figure III.A.7-97-1 in ARH-600 (Carter 1968) shows that a plutonium nitrate solution with $3 \%{ }^{240} \mathrm{Pu}$ in a cylinder less than $6.9 \mathrm{in}$. in diameter, fully water reflected, can not go critical at any plutonium concentration. This is conservative because the calciner has much less continuous volume than a cylinder. Section 5.3.2, Plutonium Nitrate Added Instead of Nitric Acid, of this CSER showed that dense calcine flooded with water or plutonium feed solutions is within allowables. For confined volumes such as the calciner, the denser the fissile material the more reactive. With results showing criticality not possible at low concentrations and calculations for dense material within allowables, the extreme condition of adding special dissolving acid several times does not lead to a critical configuration. Leaking this material to the floor would make too thin a slab to present a critical configuration. The arrangement can be judged to be within allowables, making the calciner double contingent even to a dissolving acid added to the calcine in the calciner.

\subsubsection{Oxide Density Exceeded}

5.3.13.1 Pu Density Determination. The density of the elemental plutonium in the product $\mathrm{PuO}_{2}$ powder, $\mathrm{Pu}$ density, $\mathrm{g} \mathrm{Pu} / \mathrm{cm}^{3}$ is one parameter that must be controlled for criticality safety in the prototype vertical calciner. The $\mathrm{Pu}$ density in the product powder is not the same as the overall powder bulk density, which includes the oxygen content of the $\mathrm{PuO}_{2}$ and any impurities. This bulk density is measured by the PFP Analytical Laboratory using procedure ZL-510-335, "Tap Density of Bulk Solids." on powder samples from the calciner. The tap density is a bit more dense than the bulk density, which means that the Pu density inside the powder bed is slightly less dense than that calculated from the tap density. The plutonium mass found by calorimetry of the canned powder and the measured net weight of powder inside the product may be used to calculate the fraction of powder that is elemental $\mathrm{Pu}$. This fraction is then multiplied by the overall powder's bulk density to obtain the elemental Pu density.

5.3.13.2 Maximum Calcine Density Expected. The maximum calcine bulk density expected is considerably lower than recent suggestions of $8.0 \mathrm{gm} / \mathrm{cm}^{3}$ (elemental $\mathrm{Pu}$ density, not $\mathrm{PuO}_{2}$ density). The maximum density should occur with spherical particles piled up with their centers alternating such that the lowest points of one layer are slightly lower than the highest points of the layer beneath and the highest points are slightly higher than the lowest points of the layer above. As such, the comparison of volumes between a sphere $\left(4 / 3 \pi R^{3}\right)$ and a cube $\left(D^{3}\right.$ or $\left.8 R^{3}\right)$ can't be made directly. The amount of overlap between layers can be read from Table 1-20 on page 1-27 of the 6th edition of The Chemical Engineer's Handbook (Perry \& Green, McGraw-Hill 1984). That overlap is 0.013 of the sphere's volume at both the top and bottom of each layer of spheres. The volume actually occupied by these spheres is then: 
$(4 / 3)(\pi / 8\}+(2)(0.013)=0.550$ of the total volume of space.

The theoretical density of the crystals of $\mathrm{PuO}_{2}$, not taking interstitial spaces into account, is $11.46 \mathrm{gm} / \mathrm{cm}^{3}$ (Katz \& Seaborg, The Chemistry of the Actinide Elements, Methuen \& Company, Ltd., 1957, page 279, Table 7.20).

These data yield a theoretically maximum bulk density of $\mathrm{PuO}_{2}$ powder of $(0.55)(11.46 \mathrm{gm} / \mathrm{cc})=6.30 \mathrm{gm} / \mathrm{cm}^{3}$. If the powder crystals are pure $\mathrm{PuO}_{2}$, then the elemental $\mathrm{Pu}$ density is $(0.882)(6.30)=5.56 \mathrm{gm} / \mathrm{cm}^{3}$. Assuming that the listed theoretical density of $11.46 \mathrm{gm} / \mathrm{cm}^{3}$ is accurate for directly denitrated $\mathrm{PuO}_{2}$ and not $\mathrm{PuO}_{2}$ from some other process, then we should not be able to get higher than an elemental Pu density of $5.56 \mathrm{gm} / \mathrm{cm}^{3}$.

The calciner was run and the Pu density of the product was determined. Nirider (1997) shows that for normal operations the highest recorded Pu density was $4.26 \mathrm{~g} \mathrm{Pu} / \mathrm{cm}^{3}$. If the calcine bed is held at the operating temperature and stirred as will be the case in the acid feed test, the Pu density reached a high of $4.75 \mathrm{~g} \mathrm{Pu} / \mathrm{cm}^{3}$. It is possible this value could increase further during operation without feed addition, but further increases are expected to be small. The graph in Nirider (1997) shows the increase for dry roasting and stirring was small. The maximum value expected is $5.0 \mathrm{~g} \mathrm{Pu} / \mathrm{cm}^{3}$, with $5.5 \mathrm{~g} \mathrm{Pu} / \mathrm{cm}^{3}$ considered a conservative upper limit.

5.3.13.3 Product Density Monitoring. Although the official method for determing the $\mathrm{Pu}$ density in the calciner is explained in Section 5.3.13.1, a faster unofficial method (Compton 1997c) that the calciner working crew performs while the powder is still inside the glovebox uses a 10-m graduated cylinder that is kept in the product handling area of the calciner glovebox. This cylinder is partially filled with powder to get the volume and weighed to get the weight of the powder. The overall powder bulk density is calculated from those data. That density is multiplied by the elemental $\mathrm{Pu}$ fraction in the last reported batch of product to estimate the current elemental $\mathrm{Pu}$ density. This method assumes that the density is changing relatively slowly and is fairly consistent throughout the powder bed, allowing the working crew to stop before the density limit is exceeded. If there is any doubt about the elemental Pu fraction in the product, a value of 0.88 is used, which is the theoretical maximum for perfectly pure $\mathrm{PuO}_{2}$. The assumption that the density is fairly consistent throughout the powder bed is believed reasonable due to the mixing that occurs in the bed during operation.

The latest known elemental $\mathrm{Pu}$ density is recorded on the plutonium inventory sheet, which is kept on the room wall, and in the laboratory notebook to allow tracking. If the limit of $5.5 \mathrm{~g} \mathrm{Pu} / \mathrm{cm}^{3}$ of product is approached, one of two methods will be implemented to keep from exceeding the limit. One method is to stop operating, obtain a new CSER/CPS/Posting with a higher density limit and any corresponding changes to other limits, then resume operating. This first method could also yield a new CSER/CPS Posting that eliminates the elemental Pu density limit and substitutes entirely different types of limits. The second method is to begin using "dirtier" feed (i.e., deliberately choose feeds with more impurities or deliberately add impurities to relatively clean feed) to dilute the $\mathrm{Pu}$ in the product powder. The choice between methods will be made in consultation with criticality safety, nuclear safety, and Process Engineering Personnel.

5.3.13.4 Calciner Pu Density Analysis. Determination of the calcine Pu density limit assumes a critical mass limit on calcine of $6 \mathrm{~kg}$ of plutonium or less. 
The Criticality Safety Control of Fissionable Material, HNF-PRO-537 (FDH 1997b) requires that when administrative mass limits are used to ensure criticality safety, the limit must be no more than $45 \%$ of the critical mass. A limit of $6 \mathrm{~kg}$ of plutonium therefore requires that the system must be subcritical for $13.33 \mathrm{~kg}$ of plutonium. Accordingly, the calciner is modeled as containing $13.33 \mathrm{~kg}$ of plutonium in the form of calcine.

As in previous calculations for a calciner flood, the lower section of insulation is assumed to be saturated with water. Because it has the minimum critical radius in the form of a cylinder, the solution flooding the calciner is assumed to be an aqueous solution containing $140 \mathrm{~g} \mathrm{Pu} / \ell$ in the form of plutonium nitrate, with no excess acid.

Table 13 presents the results of calculations for a calciner flood assuming an administrative mass limit of $6 \mathrm{~kg}$ of plutonium in the calciner. To ensure modeling of the most reactive case, Table 13 covers two geometries:

- The annulus full of calcine, with the remainder of the $13.33 \mathrm{~kg}$ immediately above the annulus (ann60, ann70, and annpack);

- The calcine starting in the lower portion of the filter section and extending down to the bottom of the pipe-cap dome in the calciner section (fil60, fil65, fil70, fi175, and filpack).

For both geometries, the calculated MONK6B $\mathrm{k}_{\text {eff }}$ is acceptably low $(\leq 0.935)$ regardless of calcine density.

\begin{tabular}{|l|l|l|}
\hline \multicolumn{3}{|c|}{ Table 13. Calciner Flood with a $6.0 \mathrm{~kg}$ Mass Limit } \\
\hline $\begin{array}{l}\text { Calculation } \\
\text { Number }\end{array}$ & Calculated $\mathrm{k}_{\text {eff }}$ & $\begin{array}{l}\text { Calcine } \text { Density } \\
\left(\mathrm{g} \mathrm{Pu} / \mathrm{cm}^{3}\right)\end{array}$ \\
\hline \hline ann60 & $0.8102 \pm 0.0036$ & 6.000 \\
\hline ann70 & $0.8232 \pm 0.0035$ & 7.000 \\
\hline annpack & $0.8319 \pm 0.0034$ & 8.017 \\
\hline fil60 & $0.8692 \pm 0.0042$ & 6.000 \\
\hline fil65 & $0.8945 \pm 0.0041$ & 6.500 \\
\hline fil70 & $0.9104 \pm 0.0043$ & 7.000 \\
\hline fil75 & $0.9131 \pm 0.0043$ & 7.500 \\
\hline filpack & $0.9120 \pm 0.0044$ & 8.017 \\
\hline
\end{tabular}


HNF-3908 Rev. 0

\subsection{REFERENCES}

\section{A. Drawings}

ECN-125369 to H-2-28536: "Assembly-Glovebox 188-1, " 1991, Westinghouse Hanford Company, Richland, Washington.

ECN-185589 to ECN-125369 and H-2-28536: "Assembly-Glovebox 188-1, " 1992, Westinghouse Hanford Company, Richland, Washington.

H-2-3712, Rev. 1, Sheet 1, Air Lock Full Air Flow Type Left Hand\&Right Hand, U.S. Department of Energy, Richland Operations Office, Richland, Washington.

H-2-28536, Rev. 0, Sheets 1-2, Assembly-Glovebox 188-1, U.S. Department of Energy, Richland Operations Office, Richland, Washington.

H-2-28584, Rev. 0, Sheets 1-2, Details and Assemblys-Glovebox 188-1, U.S. Department of Energy, Richland Operations Office, Richland, Washington.

H-2-33764, Rev. 3, Sheets 1-3, Glovebox 188-1 Arrangement, U.S. Department of Energy, Richland Operations Office, Richland, Washington.

H-2-95609, Rev. 0, Sheets 1-8, Calciner Assembly, U.S. Department of Energy, Richland Operations Office, Richland, Washington.

SK-2-300306, Rev. 0, Sheets 1-3, 10L/Calciner Scrubber Assembly, U.S. Department of Energy, Richland Operations Office, Richland, Washington.

SK-2-300307, Rev. 0, Sheets 1-3, 10L/Calciner Glovebox 188-1 Feed Tank, U.S. Department of Energy, Richland Operations Office, Richland, Washington.

SK-2-300310, Rev. 0, Sheets 1-2, 10L/Calciner Vacuum Trap Assembly, U.S. Department of Energy, Richland Operations Office, Richland, Washington.

\section{B. Documents}

Carter, R. D., G. D. Kiel and K. R. Ridgway, 1968, Criticality Handbook, ARH-600, 1980 Revision, Atlantic Richfield Hanford Company, Richland, Washington

Compton, J.A., 1997, Prototype Vertical Calciner Introductory Guide, HNF-SD-CP-LB-037, Rev. 0, January 23, 1997, Babcock and Wilcox Hanford Company, Richland, Washington.

Compton, J. A., 1999a, electronic-mail to E. M. Miller and K. D. Dobbin on the subject: Minimum Calcine Density Expected, dated January 25, 1999 (see Appendix F). 
Compton, J. A., 1999b, electronic-mail to E. M. Miller and K. D. Dobbin on the subject: Maximum Calcine Density Expected, dated January 25, 1999 (see Appendix F).

Compton, J. A., 1999c, electronic-mail to E. M. Miller on the subject: Product Pu Density Tracking in the Prototype Vertical Calciner, January 1999 (see Appendix F).

Compton, J. A., 1999d, Memo 15F00-99-009 to E. M. Miller on the subject: Plutonium Dioxide NonDissolution in Pure Nitric Acid, dated January 21, 1999 (see Appendix F).

Compton, J. A., 1999e, Memo 15F00-99-006 to E. M. Miller on the subject: Actual Volume Determination for Nominal 4-Liter Narrow Mouth Polybottles, dated January 18, 1999 (see Appendix F).

Erickson, D. G., 1998, CCVR 97-001, MCNP 4B Plutonium Validation, HNF-1905, Rev 1, November 11, 1998, Fluor Daniel Northwest, Richland, Washington.

FDH, 1997a, HNF-PRO-334, Criticality Safety General Requirements, Fluor Daniel Hanford Company, Richland Washington.

FDH, 1997b, HNF-PRO-537, Criticality Safety Control of Fissionable Materials, Fluor Daniel Hanford Company, Richland Washington.

FDH, 1997c, HNF-PRO-539, Criticality Safety Evaluations, Fluor Daniel Hanford Company, Richland Washington.

FDH, 1999, Plutonium Finishing Plant Final Safety Analysis Report, HNF-SD-CP-SAR-021, Fluor Daniel Hanford Company, Richland Washington.

Geiger, J.L., 1995a, CSER-95-005, PFP Vertical Denitration Calciner, WHC-SD-SQA-CSA-20392, Rev. 0, May 30, 1995, Westinghouse Hanford Company, Richland, Washington.

Geiger, J.L., 1995b, CSER-95-005 Addendum 1, Stainless Steel Insulation, WHC-SD-SQA-CSA20404, Rev. 0, December 21, 1995, Westinghouse Hanford Company, Richland, Washington.

Hammelman, J. E., 1974, Z Plant Sprinkler System Criticality Safety Analysis Report, ARH-2406, Atlantic Richfield Hanford Company, Richland, Washington.

Hess, A.L., 1994, Downloading of 10-L Containers in Glovebox 227S, WHC-SD-SQA-CSA-20372, Rev. 0, Westinghouse Hanford Company, Richland, Washington.

Hess, A.L., 1995, CSER-95-005, PFP Vertical Denitration Calciner, WHC-SD-SQA-CSA-20392, Rev. 0-A, August 7, 1995, Westinghouse Hanford Company, Richland, Washington.

Hieb, J. A., 1995, Internal Memo to C. S. Sutter on the subject: NDA Glovebox 188-1, dated June 6, 1995 (see Appendix F). 
HNF-3908 Rev. 0

Hillesland, K.E., 1997, CSER 97-004, PFP Production Denitration Calciner System, HNF-SD-SQACSA-529, Rev. 0, September 11, 1997, Fluor Daniel Northwest, Inc., Richland, Washington.

Hillesland, K.E., 1998, Addendum I to CSER-97-004, PFP Production Denitration Calciner System Disassembly, HNF-1847, Rev. 0, March 20, 1998, Fluor Daniel Northwest, Inc., Richland, Washington.

Lan, J. S., 1999, MCNP Version 4B Approval For Use Documentation \& Authorized User List, FDNW-DSL-99-004, January 12, 1999, Fluor Daniel Northwest, Richland, Washington.

Lehmkuhl, G. D., 1974, Criticality Drain Performance Study, RFP-2222, Dow Chemical U.S.A., Golden, Colorado.

Macklin, L. L., and E. M. Miller, 1992, CCVR 91-001 MONK6A Pu Validation, WHC-SD-SQA20015, Rev 0, Westinghouse Hanford Company, Richland, Washington.

Merrick, S.B., and P. M. Rickords, 1996, Technical Assessment of the PFP Vertical Direct Denitration Calciner, WHC-SD-CP-TA-009, Rev. 0, Westinghouse Hanford Company, Richland, Washington.

Miller, E. M., 1994, CCVR 94-001; MONK6B Pu Validation, WHC-SD-SQA-CSWD-20019, Westinghouse Hanford Company, Richland, Washington.

Miller, E. M., 1997, Personal Communication of E. M. Miller with G. S. Barney on May 2, 1997, Richland, Washington.

Nirider, L. T., 1997, electronic-mail to K. E. Hillesland, Vertical Calcine Product Tap Densities, dated March 18, 1997, (see Appendix F).

Stubbs, A. M., 1997, Plutonium Finishing Plant Process Flow Document, Calcination of Plutonium Nitrate Solution, PFD-Z-300-001, January 1, 1997, Babcock and Wilcox Hanford Company, Richland, Washington. 


\subsection{PEER REVIEW}

\subsection{Technical Peer Review}

D. G. Erickson of the Criticality and Shielding group in FDNW Specialty Engineering carried out the technical peer review of HNF-3908, Rev. 0, CSER 99-001, PFP Lab Denitrating Calciner, for which the following comments are provided.

The technical arguments given in the report were found to be sound for qualifying the criticality safety of the PFP Lab vertical denitrating calciner located in Glovebox 188-1 in Room 188 of the 234-5Z Building The maximum mass limit of $4.5 \mathrm{~kg}$ and nitric acid feed only are both significant limits that help assure the criticality safety of the operation. All credible contingencies resulted in $k_{\text {eff }}$ that are within allowables.

The review of this CSER showed that the normal conditions were analyzed adequately and very conservatively modeled the actual conditions that would be found in the glovebox. Some of the conservatisms were: $140 \mathrm{~g} \mathrm{Pu} / \ell$ or $450 \mathrm{~g} \mathrm{Pu} / \ell$ plutonium nitrate solution for all feed materials, excessive amounts of holdup on the glovebox floors, nominal reflection on all containers, and full water reflection of the glovebox.

Analysis of the off-normal conditions also incorporated most if not all of the above mentioned conservatisms, as well as including additional conservatisms that bound any credible off-normal conditions. The analysis shows that even if the glovebox were to be flooded, improper materials were brought into the glovebox, container spacing were lost, or operations continued without proper material collection containers in place, the system is still subcritical. Plutonium nitrate solutions in place of the allowed clean nitric acid feed solution is analyzed, and shown to be acceptable. In all cases adequate margins of safety exist to assure that the operations to be performed in the glovebox does not pose any criticality concerns. For the fire analysis non-credible scenarios that have unlikely material in the glovebox and full flooding were postulated, and were shown to be acceptable.

The analysis of the postulated seismic event, also, very conservatively modeled any credible rearrangement of the materials and containers in the glovebox. The model used a sphere of $\mathrm{PuO}_{2}$ with full water reflection surrounding the spherical model. It is not credible to believe that any event could cause the materials contained in the glovebox to even approach the modeled geometry.

The report was reviewed for technical accuracy, consistency, coverage of all credible contingencies, and adequacy of limits, and found to be sound. Many comments regarding he document format and content were made and have been adequately resolved. All editorial comments have also been adequately resolved.

The input and output files from all new computer calculations were also reviewed. The input files were checked for model adequacy, material densities, geometry, and container volumes. The $\mathrm{k}_{\mathrm{eff}}$ values given in the report were verified against the results in the output files, and the outputs were reviewed for adequate convergence. It was noted that the ${ }^{10} \mathrm{~B}$ in the borosilicate glass was included in some of the vessels, and there were no operational controls to assure that the ${ }^{10} \mathrm{~B}$ was present. The ${ }^{10} \mathrm{~B}$ was removed from all final models, so no controls on its presence are necessary.

This reviewer affirms that based on the analysis contained in CSER 99-001, the operations proposed for the PFP Lab denitrating calciner in Glovebox 188-1 are safe from a criticality standpoint. 


\section{CHECKLIST FOR TECHNICAL PEER REVIEW}

Document Reviewed: CSER 99-001: PFP LAB DENITRATING CALCNNER

Yes No* NA

$[\mathrm{X}][\mathrm{X}][\mathrm{]}$

$[\mathrm{X}][\mathrm{C}] \mathrm{[}]$

[X] [ ] [ ]

$[\mathrm{X}][\mathrm{C}] \mathrm{[}]$

$[\mathrm{X}][\mathrm{X}] \mathrm{C}$

$[\mathrm{X}][\mathrm{]}[\mathrm{C}$

$[\mathrm{X}][\mathrm{X}[\mathrm{]}$

$[\mathrm{X}][\mathrm{]}[\mathrm{]}$

$[\mathrm{X}][\mathrm{X}] \mathrm{C}$

$[\mathrm{X}][$ ] [ ]

$[\mathrm{X}][\mathrm{]}[\mathrm{]}$

$[\mathrm{X}][\mathrm{X}][\mathrm{T}$

$[\mathrm{X}][\mathrm{X}] \mathrm{C}]$

$[\mathrm{X}][\mathrm{X}][\mathrm{]}$

$[\mathrm{X}] \quad[\mathrm{X}]$

[X] [ ] [ ]
[X] [ ] [ ]

Problem completely defined.

Necessary assumptions explicitly stated and supported.

Computer codes and data files documented.

Data used in calculations explicitly stated in document.

Data checked for consistency with original source information as applicable.

Mathematical derivations checked including dimensional consistency of results.

Models appropriate and used within range of validity or use outside range of

established validity justified.

Hand calculations checked for errors. Spreadsheet results should be treated exactly the same as hand calculations.

Software input correct and consistent with document reviewed.

Software output consistent with input and with results reported in document reviewed.

Limits/criteria/guidelines applied to analysis results are appropriate and referenced. Limits/criteria/guidelines checked against references.

Safety margins consistent with good engineering practices.

Conclusions consistent with analytical results and applicable limits.

Results and conclusions address all points required in the problem statement.

**Review calculations, comments, and/or notes are attached.

Document approved (i.e., the reviewer affirms the technical accuracy of the document).

Traceability

David G. Erickson

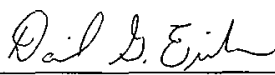

Reviewer: (Printed and Signed)

Date

* $\quad$ All "NO" responses must be explained below or on an additional page.

** Any calculations, comments, or notes generated as part of this review should be signed, dated and attached to this checklist. 
HNF-3908 Rev. 0

\subsection{Independent Technical Peer Review}

Independent peer review documented on the Checklist for Independent Technical Peer Reviewer on the next page. 


\section{CHECKLIST FOR INDEPENDENT TECHNICAL PEER REVIEW}

\section{Document Reviewed: CSER 99-001: PFP LAB DENITRATING CALCINER}

\section{Yes No* NA}

[X] [ ] [ ]

[X] [ ] [ ]

$[\mathrm{X}][\mathrm{]}[]$

[]$[X][]$

[X] [ ] [ ]

[X] [ ] [ ]

$[X][][]$

[X] [ ] [ ]

[ ] $[\mathrm{X}]$ [ ]

[ ] [X] [ ]

[X] [ ] [ ]

$[\mathrm{X}][\mathrm{X}] \mathrm{C}]$

$[\mathrm{X}][\mathrm{C}] \mathrm{C}]$

$[\mathrm{X}][\mathrm{X}][\mathrm{C}$

$[\mathrm{X}]$

[ ]

[X] [ ] [ ]

$[\mathrm{X}][$ ] [ ]
Problem completely defined.

Necessary assumptions explicitly stated and supported.

Computer codes and data files documented.

Data used in calculations explicitly stated in document.

Data checked for consistency with original source information as applicable.

Mathematical derivations checked including dimensional consistency of results.

Models appropriate and used within range of validity or use outside range of established validity justified.

Hand calculations checked for errors. Spreadsheet results should be treated exactly the same as hand calculations.

Software input correct and consistent with document reviewed.

Software output consistent with input and with results reported in document reviewed.

Limits/criteria/guidelines applied to analysis results are appropriate and referenced. Limits/criteria/guidelines checked against references.

Safety margins consistent with good engineering practices.

Conclusions consistent with analytical results and applicable limits.

Results and conclusions address all points required in the problem statement.

**Review calculations, comments, and/or notes are attached.

Document approved (i.e., the reviewer affirms the technical accuracy of the document).

Traceability

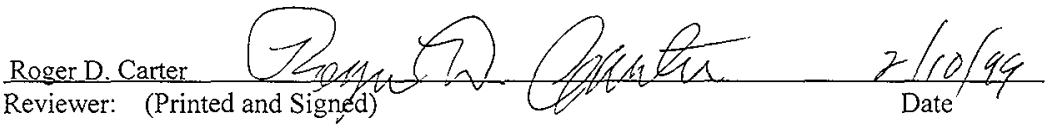

* $\quad$ All "NO" responses must be explained below or on an additional page.

** Any calculations, comments, or notes generated as part of this review should be signed, dated and attached to this checklist.

I commented that there is no table of materials and compositions/atom densities. I believe that the information is much easier to follow and review with such a table. Its lack does not invalidate the document. I reviewed no computer input or output. 
HNF-3908 Rev. 0

APPENDIX A. MCNP 4B COMPUTER CODE VALIDATION 
HNF-3908 Rev. 0

This page intentionally left blank 


\section{A.1 VALIDATION PROCEDURE}

The validation of the computer code methods used in this analysis consisted of testing that the code and neutron cross-sections calculations on known critical configurations, benchmark experiments, that have the fissile isotopes in systems being studied match the benchmark cases $\mathrm{k}_{\mathrm{eff}}$. Such analyses determine a calculational bias (the deviations of calculated $\mathrm{k}_{\text {eff }}$ values from unity for the benchmark cases) and the uncertainties culminating from the experimental and calculational errors and spread in the values calculated for benchmark cases.

The safety criteria for future calculations on undetermined systems requires that the bias-adjusted $\mathrm{k}_{\mathrm{eff}}$ does not exceed $\mathrm{k}_{\mathrm{limit}}$ at the $95 \%$ confidence level. This is expressed by the following formula:

$$
\mathrm{k}_{\mathrm{eff}}=\mathrm{k}_{\text {calc }}-\text { bias }+1.645 * \sigma_{\text {calc }} \leq \mathrm{k}_{\text {limir }}
$$

where $\mathrm{k}_{\text {calc }} \quad=\mathrm{k}$ value given by MCNP 4B calculation for the system in question,

bias $=$ mean difference $\left(\mathrm{k}_{\text {calc }}-1.0\right)$ for benchmark criticals plus the product of the standard deviation of this mean difference times a multiplier for incorporating $95 \%$ of the population at the $95 \%$ confidence level for the number of degrees of freedom in the validation with benchmark criticals,

$1.645=$ number of standard deviations in standard normal distribution required to yield $95 \%$ of the distribution ( $95 \%$ confidence) of a one-sided distribution,

$\sigma_{\text {calc }}=$ standard deviation given by MCNP $4 \mathrm{~B}$ calculation for system in question, and

$\mathrm{k}_{\text {limit }}=0.95$ for plutonium systems, generally.

Thus, the bias-adjusted $\mathrm{k}_{\text {eff }}$ includes the statistical uncertainties in both the particular MCNP 4B calculation and the validation calculations to benchmark experiments.

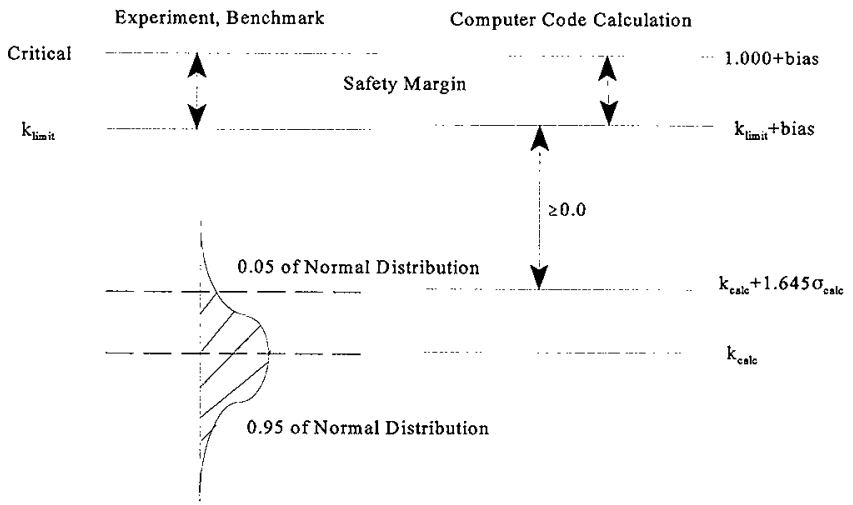

Figure A.1 Logic of Validation Procedure 


\section{A.2 GENERIC VALIDATION FOR PLUTONIUM SYSTEMS}

A report by J. S. Lan, MCNP Version $4 B$ Approval For Use Documentation \& Authorized User List (Lan 1999), presents the results of calculations to determine a generic bias for plutonium configurations, as encountered in the Plutonium Finishing Plant. One hundred and forty three benchmark experiments were calculated. There were different material types that were considered in the plutonium validation calculations:

- Plutonium metal,

- Plutonium oxide,

- Plutonium solutions,

- Plutonium solutions with cadmium (a neutron poison),

- Water and polystyrene moderators, and

- Water, plexiglass, paraffin, polyethylene, and steel and concrete reflectors

$A k_{\text {limit }}$ of 0.95 is used when the cases to be calculated are predominately composed of these bench marked material. For materials which are analyzed, but not benchmarked, a lower $\mathrm{k}$ limit is to be used (usually $\mathrm{k}_{\text {limit }}=0.90$ ) per HNF-PRO-537.

The safety criteria for future calculations on undetermined systems requires that the lower tolerance limit $b_{L}$ is calculated such that there is $95 \%$ confidence that $95 \%$ of the population is above that limit. This is expressed by the following formula:

$$
\mathrm{b}_{\mathrm{L}}=\mathrm{k}_{\mathrm{avg}}-\mathrm{K}_{\mathrm{b}} * \sigma_{\mathrm{avg}}
$$

where $b_{L}=$ lower tolerance limit for $95 \%$ confidence that $95 \%$ of population is below this limit,

$\mathrm{k}_{\text {avg }}=$ the average of the $\mathrm{k}_{\text {eff }}$ 's calculated by MCNP $4 \mathrm{~B}$,

$\mathrm{K}_{\mathrm{b}}=$ a multiplier found from statistical tables for non-central t-distribution, and depends on number of degrees of freedom, and

$\sigma_{\text {avg }}=$ standard deviation of the MCNP $k_{\text {cff }}$ 's.

Bias is calculated by the following formula:

$$
\text { bias }=b_{L}-1.000
$$

where bias $\quad=$ mean difference $\left(k_{\text {calc }}-1.0\right)$ for benchmark criticals plus the product of the standard deviation of this mean difference times a multiplier for incorporating $95 \%$ of the population at the $95 \%$ confidence level for the number of degrees of freedom in the validation with benchmark criticals,

$\mathrm{b}_{\mathrm{L}}=$ lower tolerance limit for $95 \%$ confidence that $95 \%$ of population is below this limit, and $1.000=$ the average of the $k_{\text {eff }}$ 's for the critical experiments.

The bias for the plutonium metal group was significantly different than for all other groups. For this reason, it was concluded that separate bias values for metal and non-metal groupings would be appropriate. The lower tolerance limit for the metal group (17 benchmark critical experiments) calculated to be 0.9884 . The lower tolerance limit for the non-metal group (126 benchmark critical 
experiments) calculated to be 0.9991 . These lower tolerance limits yielded the bias appropriate for each material category:

- Plutonium metal

- Plutonium non-metal bias is -0.0116 , bias is -0.0009 .

For conservatism, these calculated biases were recommended to be increased to:

- Plutonium metal recommended bias is -0.0150 ,

- Plutonium non-metal recommended bias is -0.0050 .

The safety criteria for future calculations on undetermined systems requires that the bias-adjusted $k_{\text {eff }}$ does not exceed 0.95 at the $95 \%$ confidence level. This is expressed by the following formula:

$$
\mathrm{k}_{\text {eff }}=\mathrm{k}_{\text {calc }}-\text { bias }+1.645 * \sigma_{\text {calc }} \leq \mathrm{k}_{\text {limit }}
$$

where $\mathrm{k}_{\text {calc }} \quad=\mathrm{k}$ value given by MCNP $4 \mathrm{~B}$ calculation for system in question,

bias $=-0.015$ for $\mathrm{Pu}$ metal, and -0.005 for $\mathrm{Pu}$ non-metal systems,

$1.645=$ a constant number of standard deviations for .95 of the distribution for a one-sided standard normal distribution

$\sigma_{\text {calc }}=$ standard deviation given by MCNP $4 \mathrm{~B}$ calculation for system in question, and

$\mathrm{k}_{\text {limit }}=0.95$ for plutonium systems, generally.

$\mathrm{k}_{\text {limit }}$ is generally taken to be 0.95 for plutonium systems, but, $k_{\text {limit }}$ of 0.90 may be used if the moderator or reflector in the system being analyzed were not included in the materials evaluated in the MCNP 4B criticality code validation.

For a standard deviation $\left(\sigma_{\text {call }}\right)$ of 0.002 or less, the $k_{\mathrm{eff}}$ value for non-metal systems is:

$$
\begin{gathered}
k_{\text {calc }}-(-0.005)+1.645 * 0.002 \leq 0.95 \text {, or [Plutonium non-metal] } \\
k_{\text {calc }} \leq 0.95+(-0.005)-1.645 * 0.002=0.942 \text {. [Plutonium non-metal] }
\end{gathered}
$$

On this basis, it is determined that the true $\mathrm{k}_{\mathrm{eff}}$ of an analyzed configuration with plutonium will not exceed 0.95 with a $95 \%$ confidence level for plutonium non-metal systems if the calculated value $\left(k_{\text {calco }}\right.$, and $\sigma \leq 0.002$ ) is limited to a maximum value of $\mathbf{0 . 9 4 2}$. 
HNF-3908 Rev. 0

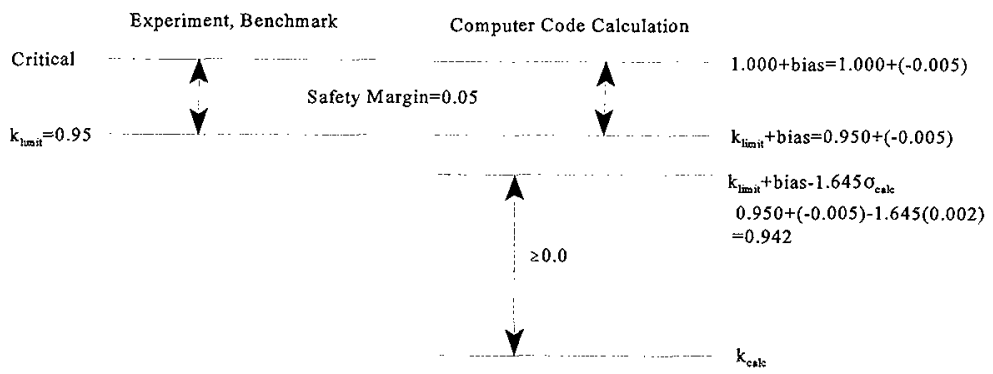

Figure A.2 Implementation of Validation Procedure

\section{A.3 VALIDATION OF MCNP 4B}

The validation of the MCNP4B code on the new computing system, Intergraph ${ }^{\mathrm{TM}}, 400 / 450 \mathrm{MHZ}$ Pentium II, personal computers was documented in Lan, 1999. The essence of the validation was cross-correlation of calculational results obtained with this code version and results of critical experiments, as reported in MCNP Version 4B Approval for Use Documentation \& Authorized User List (Lan 1999). 
HNF-3908 Rev. 0

APPENDIX B. MONK6B COMPUTER CODE VALIDATION 
HNF-3908 Rev. 0

This page intentionally left blank 


\section{B.1 MONK VALIDATION PROCEDURE}

The validation of the methods used in the analysis consists of testing the ability of the code and neutron cross-sections in calculations of known critical configurations, which are various benchmark experiments with the fissile material in question. Such analyses determine a calculational bias (the deviations of calculated $k_{\text {eff }}$ values from unity for the benchmark cases) and the uncertainties culminating from the experimental and calculational errors.

The safety criteria for future calculations on undetermined systems requires that the bias-adjusted $\mathrm{k}_{\text {eff }}$ does not exceed 0.95 at the $95 \%$ confidence level. This is often expressed by the following formula;

$$
\mathrm{k}_{\mathrm{eff}}=\mathrm{k}_{\mathrm{calc}}-\text { bias }+\left(\mathrm{U}_{\mathrm{b}}^{2}+\mathrm{U}_{\mathrm{c}}^{2}\right)^{3 / 2} \leq 0.95
$$

where $\mathrm{k}_{\text {calc }} \quad=\mathrm{k}$ value given by calculation for system in question,

bias $=$ mean difference $\left(k_{\text {calc }}-1.0\right)$ for benchmark criticals

$\mathrm{U}_{\mathrm{b}}=95 \%$ confidence level uncertainty in the bias determination,

and $U_{c}=95 \%$ confidence level uncertainty in new calculation.

Thus, the bias-adjusted $k_{\text {eff }}$ includes the statistical uncertainties. As described in the next section of statistical method of determining the target $\mathrm{k}_{\text {eff }}$ was used for setting the $\mathrm{k}_{\text {eff }}$ bias for the computer calculations of this CSER.

\section{B.2 GENERIC MONK VALIDATION FOR PLUTONIUM SYSTEMS}

A report by L. L. Macklin and E. M. Miller, MONK6A Pu Validation (Macklin and Miller 1992), presents the results of calculations to determine a generic bias for plutonium configurations, as encountered in the Plutonium Finishing Plant. Seventy benchmark experiments were calculated, ranging from simple metal spheres to highly dilute $(9 \mathrm{~g}$ plutonium per liter) plutonium nitrate solution spheres, and also compacts of $\mathrm{PuO}_{2}$ blended with polystyrene. A mean $\mathrm{k}_{\text {eff }}$ value of 1.0047 was determined over the full experimental range, with an overall standard deviation of 0.0097 .

The direct calculational bias is thus +0.0047 (average $k_{\text {eff }}$ greater than unity). Accounting for the uncertainties using a tolerance limit analysis, the report then concludes that

At least $95 \%$ of all critical experiments of this type computed by the MONK6A code will produce calculated $\mathrm{k}_{\mathrm{eff}}$ values greater than 0.9857 with $95 \%$ confidence.

For a standard deviation $(\sigma)$ of 0.01 or less for the convergence of a future calculation $\left(\mathrm{U}_{\mathrm{c}}\right)$, the 0.9857 value is lowered to 0.9855 . Rounded conservatively, a value of +0.015 can be used for [ -bias + $\left.\left(\mathrm{U}_{\mathrm{b}}^{2}+\mathrm{U}_{\mathrm{c}}^{2}\right)^{1 / 2}\right]$. On this basis, it is determined that the true $\mathrm{k}_{\mathrm{eff}}$ of an analyzed configuration with plutonium will not exceed 0.95 with a $95 \%$ confidence level if the calculated value $\left(\mathrm{k}_{\text {calc }}, \sigma \leq 0.01\right)$ is limited to a maximum value of $\mathbf{0 . 9 3 5}$. 
HNF-3908 Rev. 0

The $95 \%$ confidence level on $99.9 \%$ of the data is 0.9699 . So a subcritical margin of $5 \%$ is $3.5 \%$ larger than the uncertainties between the $95.0 \%$ and $99.9 \%$ coverage of the benchmark data.

\section{B.3 VALIDATION OF MONK6B}

The validation of the MONK6B code on the SUN microcomputers was documented in Miller (1994). The essence of the validation was cross-correlation of calculational results obtained with this code version and computer with results for identical input models done on the CRAY machine with MONK6A, as reported in the previous subsection. Also, the equivalence of MONK6B to MONK6A was well documented by the code vendors, the United Kingdom Atomic Energy Authority, in the verification package supplied with the software.

The abstract from CCVR 94-001 summarizes the validation study as follows;

The MONK6B validation for bare plutonium and plutonium water systems on the SUN computer and operating system is established in this report. Because the calculational method and nuclear cross-sections have not changed from the MONK6A code to the MONK6B code, the bias determination done for MONK6A is valid for MONK6B.

Macklin, L. L., and E. M. Miller, 1992, CCVR 9I-001 MONK6A Pu Validation, WHC-SD-SQA20015, Rev 0, Westinghouse Hanford Company, Richland, Washington.

Miller, E. M., 1994a, CCVR 94-001; MONK6B Pu Validation, WHC-SD-SQA-CSWD-20019, Westinghouse Hanford Company, Richland, Washington.

Miller, E. M., 1994b, CCVR 94-002; MONK6B - Software Quality Assurance Plan, WHC-SD-SQACSWD-20017

ANSWERS, 1992 MONK6 - Monte Carlo Code Criticality Calculations Rev. 5. AEEW R2248, United Kingdom Atomic Energy Authority. 


\section{APPENDIX C. MCNP INPUT FILES}

Plots of MCNP Model Geometry and Materials Used to Analyze the Base Case Model and the MCNP Input Listings.

Figure Title Page

Figure C-1. Horizontal cross section of upper level. $\mathrm{C}-4$

Figure C-2. Horizontal cross section of lower level.

Figure C-3. Vertical cross section of base case model showing feed tank, diaphragm pump, scrubber waste tank, and intermediate floor.

Figure C-4. Vertical cross section of base case model through the centerline of the scrubber and calciner.

Figure C-5. Vertical cross section of base case model through the centerline of the calciner. ... C-8

Figure C-6. Horizontal cross section through the upper part of the calciner showing the three silicon carbide filters, the agitator rod in the center.

Figure C-7. Horizontal cross section of upper level of contingency analysis for the base case model with three polybottles.

Figure C-8. Vertical cross section of contingency analysis for the base case model showing one of the three 3 liter polybottles.

Table C-1. Volumes and Masses in MCNP Model of Base Case. ................ C-12

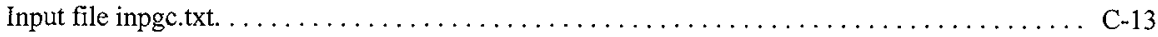

diff inpge.txt inpgeno txt. . . . . . . . . . . . . . . . . . . . . .

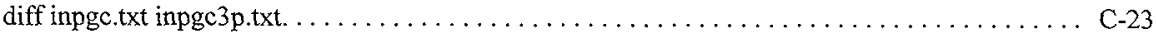

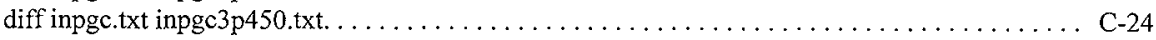

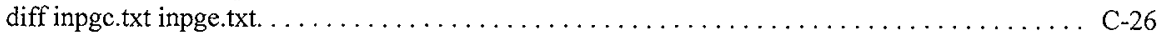

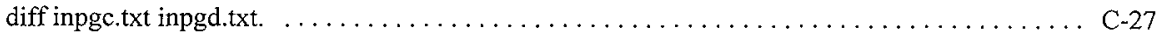


HNF-3908 Rev. 0

This page intentionally left blank 
HNF-3908 Rev. 0

Plots of MCNP Model Geometry and Materials Used to Analyze the Base Case Model and the MCNP Input Listings. 
$01 / 28 / 9916: 35: 46$

glovebox calciner 188-1 $1^{\prime \prime}$ water around al1

containers and vessels

probid $=01 / 28 / 9916: 34: 44$

basis:

$(1.000000,0.000000,0.000000)$

$(0.000000,2.000000,0.000000)$ origin:

( $70.00, \quad 160.00,20.00)$

extent $=(250.00,250.00)$

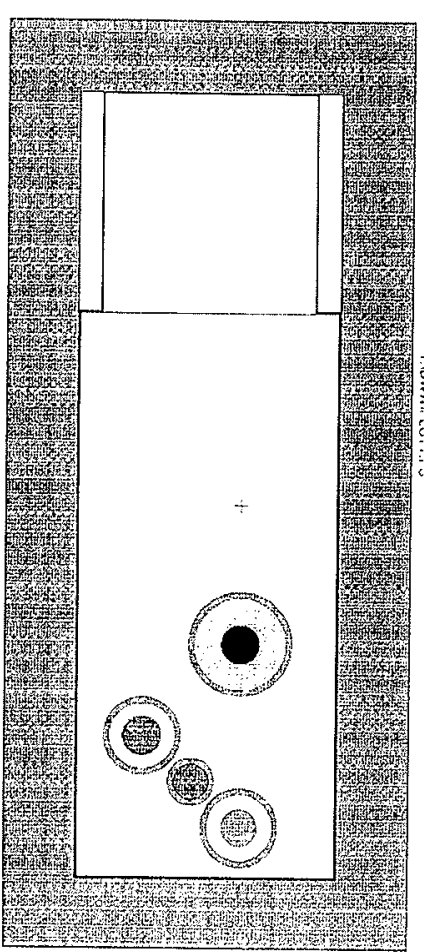

한.

蛋

is 8

点年?

字?

呙罗

点 옹.

\%

con

\& $\Omega$

ס

प.

i

풍용

\%용

号

8 实

芯

贾

㝒点

के

0

司宫

果氛

\&

$\stackrel{0}{\circ}$

(1) \$

尺

的寻

卢

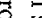

号

菅

更睗

舟

N贯

u용

$5 \%$

宫总

$\stackrel{\overrightarrow{0}}{\overrightarrow{0}}$

它

용

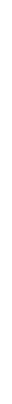




\section{HNF-3908 Rev. 0}

Figure C-2. Horizontal cross section of lower level of the base case model showing (from right to left) the two load out cans, the product receiver vessel, and the two scrubber waste tanks. Each is surrounded by $2.54 \mathrm{~cm}$ ( $1 \mathrm{in}$.) of water.

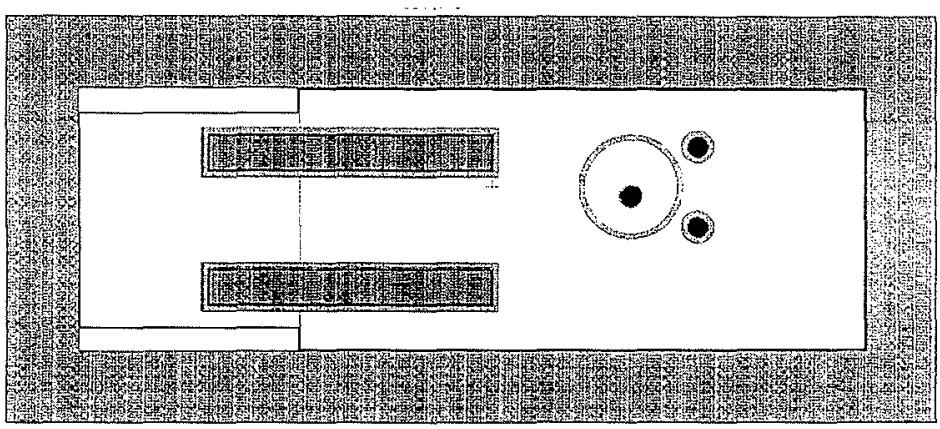

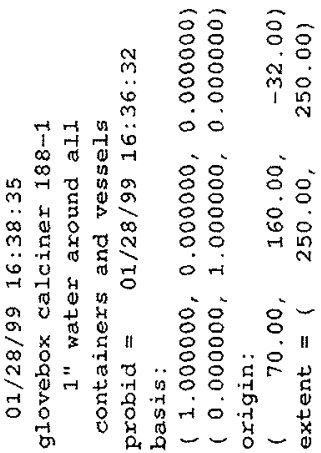


HNF-3908 Rev. 0

Figure C-3. Vertical cross section of base case model showing feed tank, diaphragm pump, scrubber waste tank, and intermediate floor. The upper left section is the upper level of the main section. The lower left section is the lower level of the main section. The upper right section is the attic level. The middle right section is the space between the attic and annex outside the glovebox. The lower right section is the annex. There is a two inch layer of water on the floor of the main section and annex.
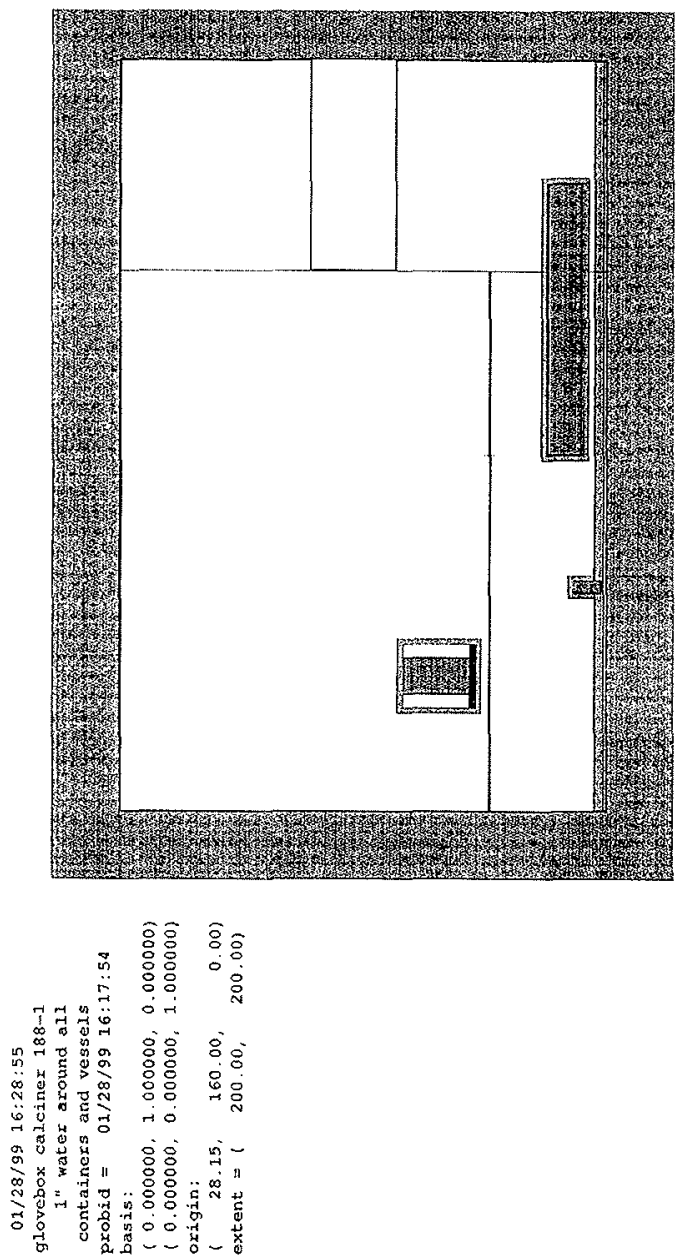


\section{HNF-3908 Rev. 0}

Figure C-4. Vertical cross section of base case model through the centerline of the scrubber and calciner. The upper region of the scrubber is feed solution and the lower region is precipitated solids.

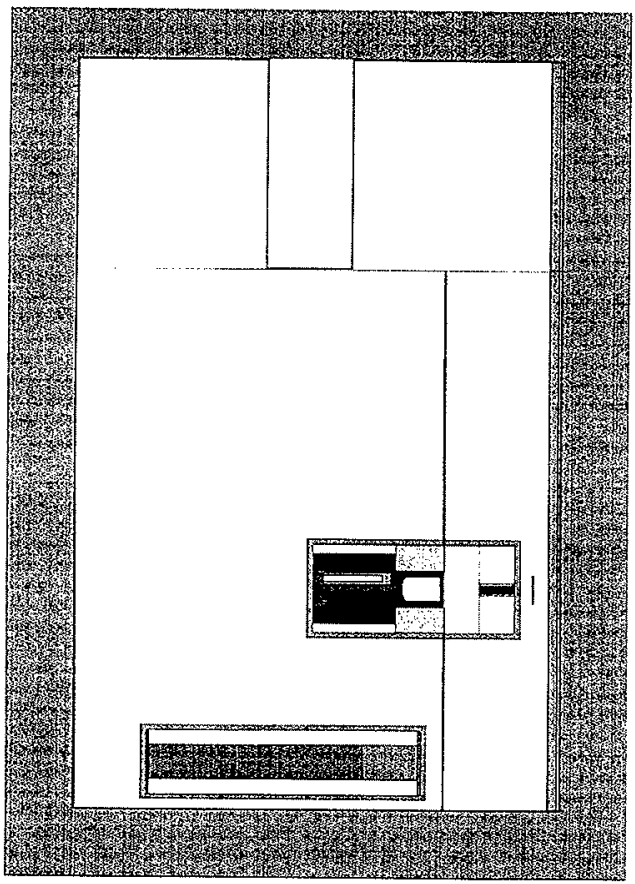

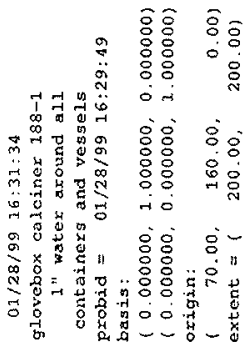


Figure C-5. Vertical cross section of base case model through the centerline of the calciner. The calciner is resting on the intermediate floor. Two of the three silicon carbide filters can be seen in the upper part of the calciner. The agitator rod extends down the center between the filters. The outer areas of the upper and lower parts of the calciner are wrapped in insultation. The product receiver vessel is shown below the calciner. The product delivery tube extends from inside the calciner dome to the top of the product receiver vessel. A deposit of plutonium oxide is shown below the product receiver vessel, representing a spill of product. The diaphragm pump can be seen to the lower left of the calciner.
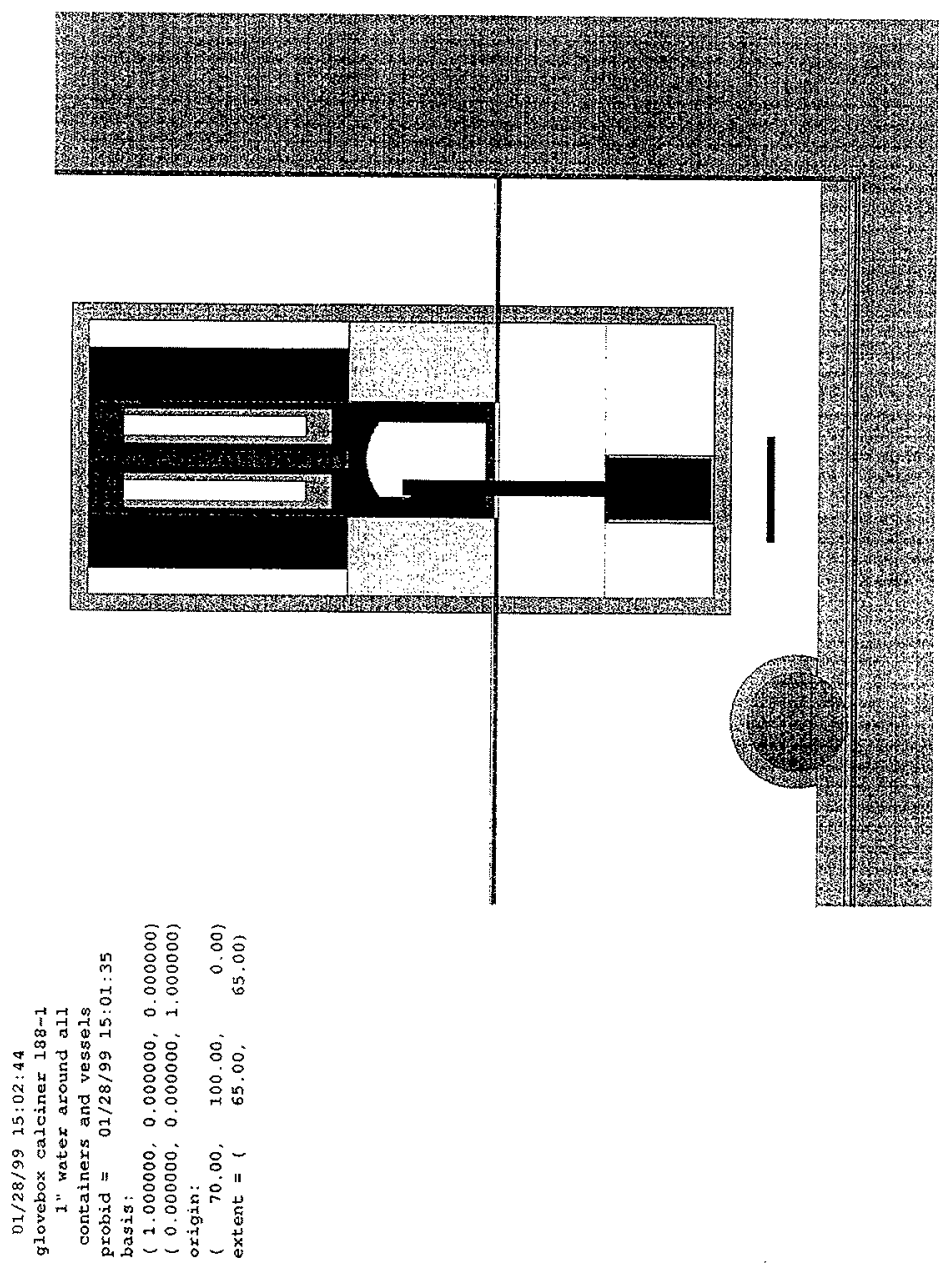
Figure C-6. Horizontal cross section through the upper part of the calciner showing the three silicon carbide filters, the agitator rod in the center, the outside vessel wall, the insulation, and the $2.54 \mathrm{~cm}$ (1 in.) water layer surrounding the calciner.
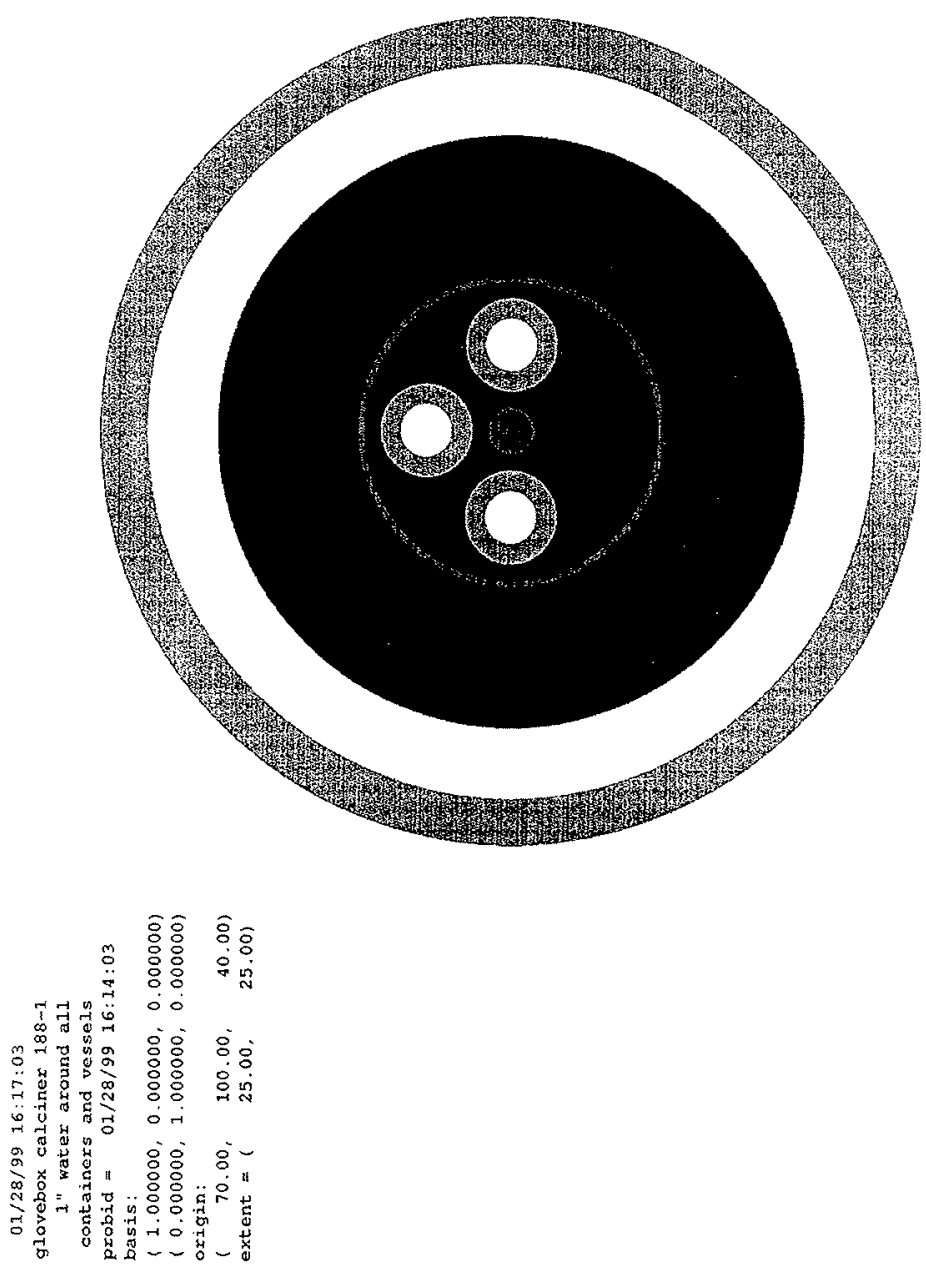
Figure C-7. Horizontal cross section of upper level of contingency analysis for the base case model with three polybottles filled with solution outside the glovebox close to the scrubber, feed tank, and calciner. Additional water reflection outside the glovebox was added to maintain one foot of water reflection around the polybottles.

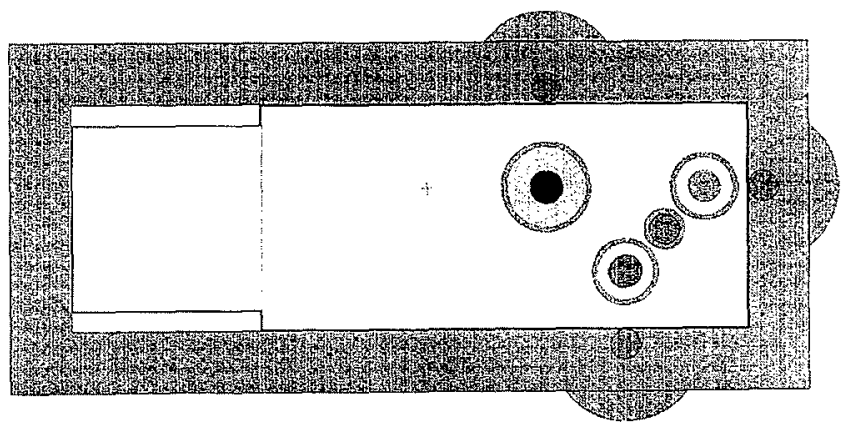

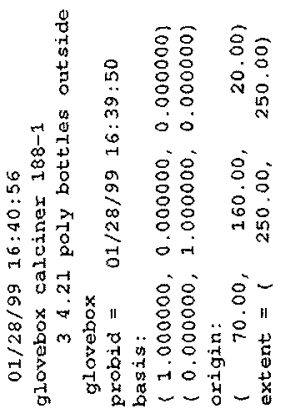


$01 / 29 / 99 \quad 12: 57: 23$

calciner glovebox 188-1, I"

water around all, $5.5 \mathrm{~g} \mathrm{pu} / \mathrm{cc}$,

3-3L polybottles

probid $=01 / 29 / 9912: 55: 06$

basis:

$(1.000000,0.000000,0.000000)$

$(0.000000,0.000000,1.000000)$ origin:

$(70.00, \quad 100.00,20.00)$

extent $=(250.00,250.00)$

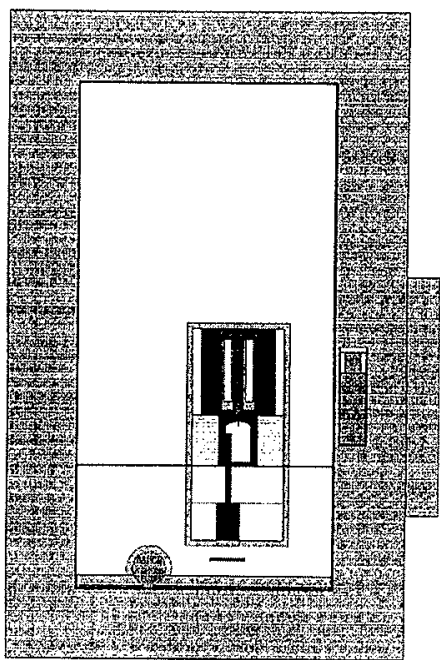


Volumes and Masses in MCNP Model of Base Case

Table $\mathrm{C}-1$ summarizes the volumes and plutonium masses for the containers and vessels in the base case MCNP model, inpgc. These masses were selected to conservatively represent the extent of likely normal and abnormal conditions and to be consistent with previous calciner analyses.

\begin{tabular}{||c|c|c|}
\hline \multicolumn{2}{|c|}{ Table C-1. Volumes and Masses in MCNP Model of Base Case } \\
\hline \hline Component & Volume, $\mathrm{cm}^{3}$ & Pu mass, $\mathrm{g}$ \\
\hline Diaphragm pump & 897 & 126 \\
\hline Pile under product receiver & 174 & 956 \\
\hline Product receiver & 948 & 5216 \\
\hline Load out vessel 1 & 552 & 3035 \\
\hline Load out vessel 2 & 552 & 3035 \\
\hline Scrubber waste tank 1 & 23423 & 3279 \\
\hline Scrubber waste tank 2 & 23423 & 3279 \\
\hline Feed tank & 5910 & 827 \\
\hline Scrubber solution & 18727 & 2622 \\
\hline Scrubber solids & 4928 & 9886 \\
\hline 4.2L polybottle & 4200 & 588 \\
\hline Calciner upper & 4403 & 24218 \\
\hline Calciner lower & 2423 & 13325 \\
\hline Downcomer & 118 & 648 \\
\hline & & 71040 \\
\hline Total & 90677 & \\
\hline
\end{tabular}




\section{MCNP Input File for Base Case and listing of differences from base case for other cases}

\section{Input file inpgc.txt}

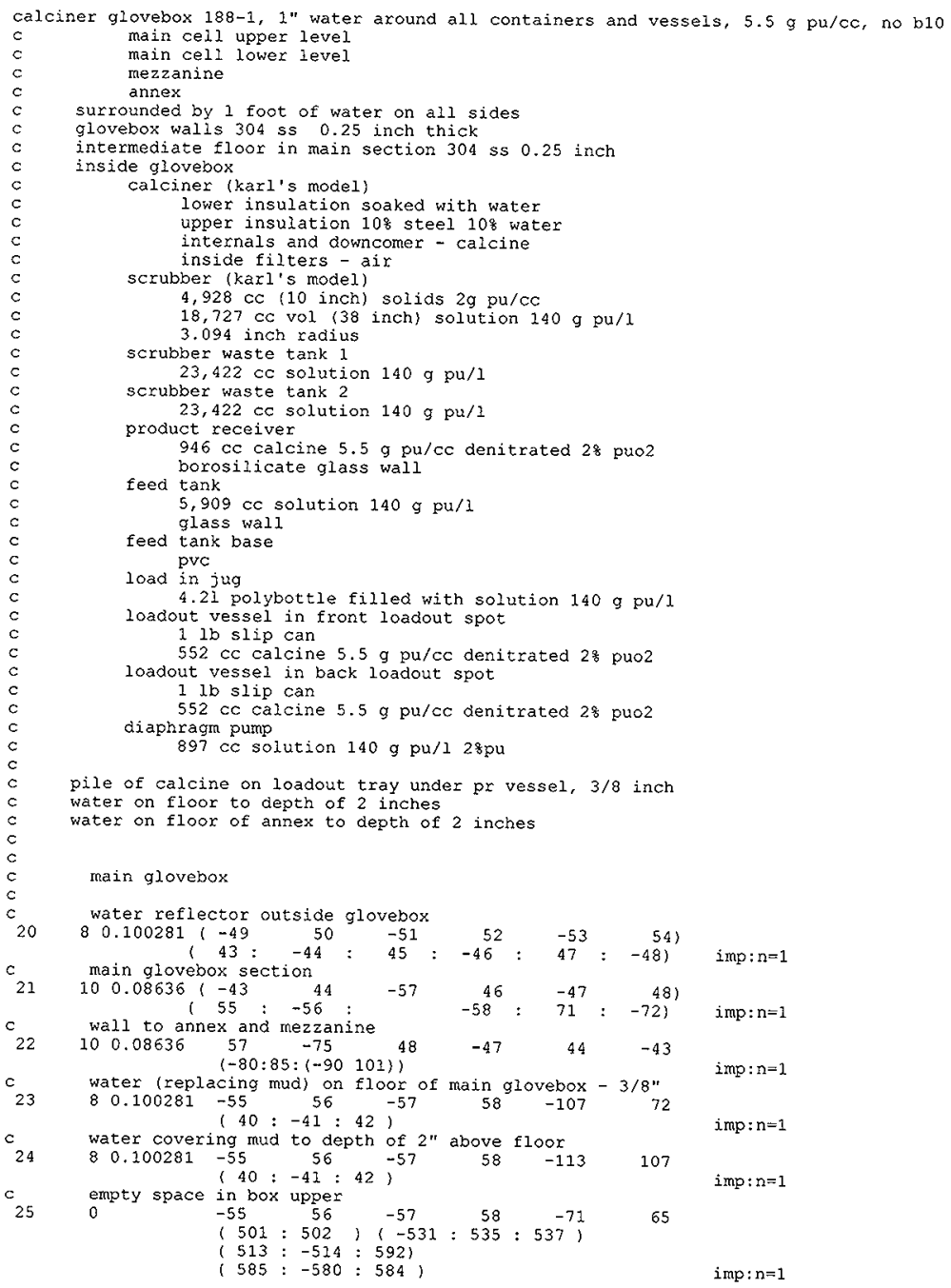


HNF-3908 Rev. 0

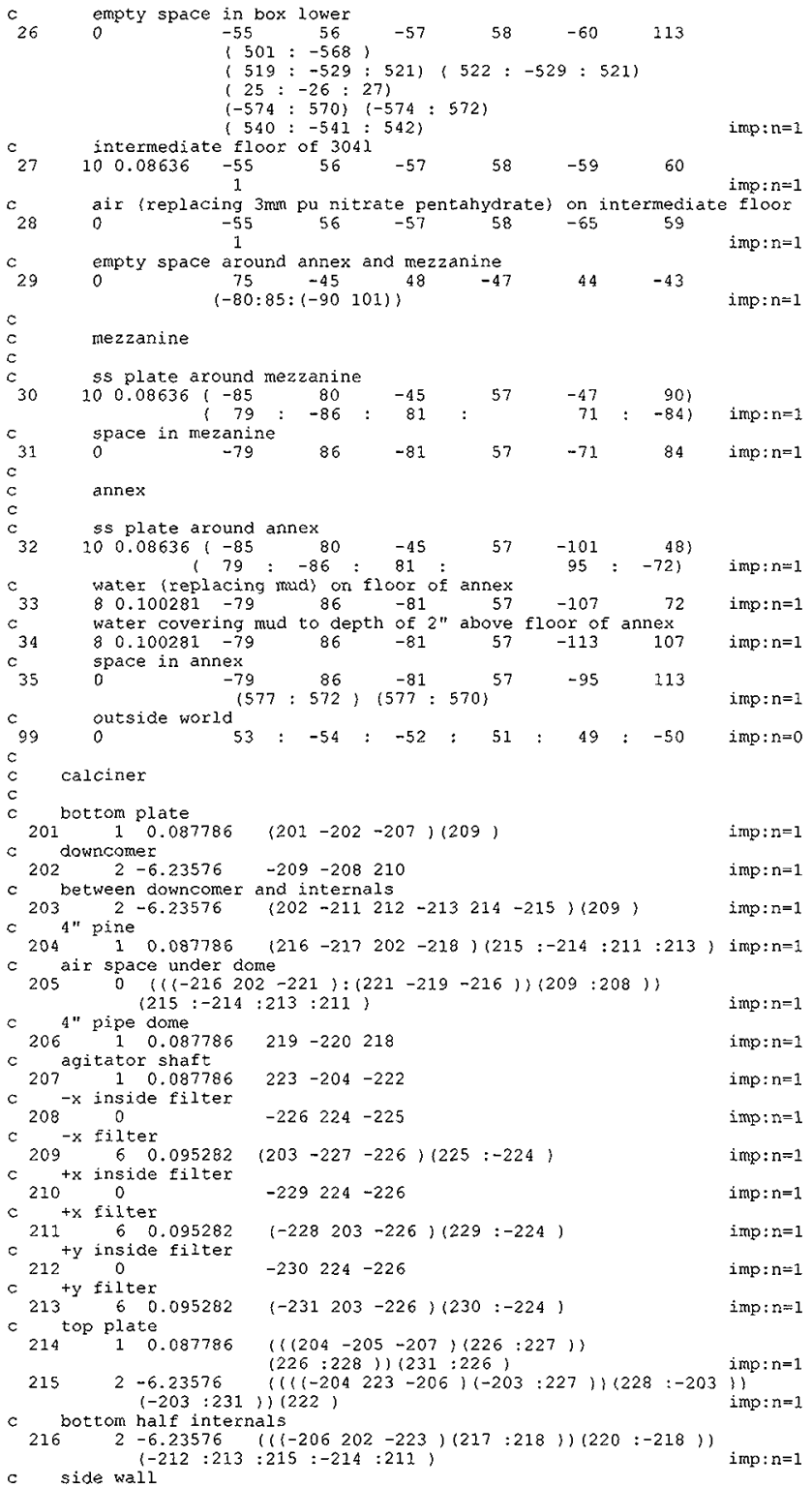


HNF-3908 Rev. 0

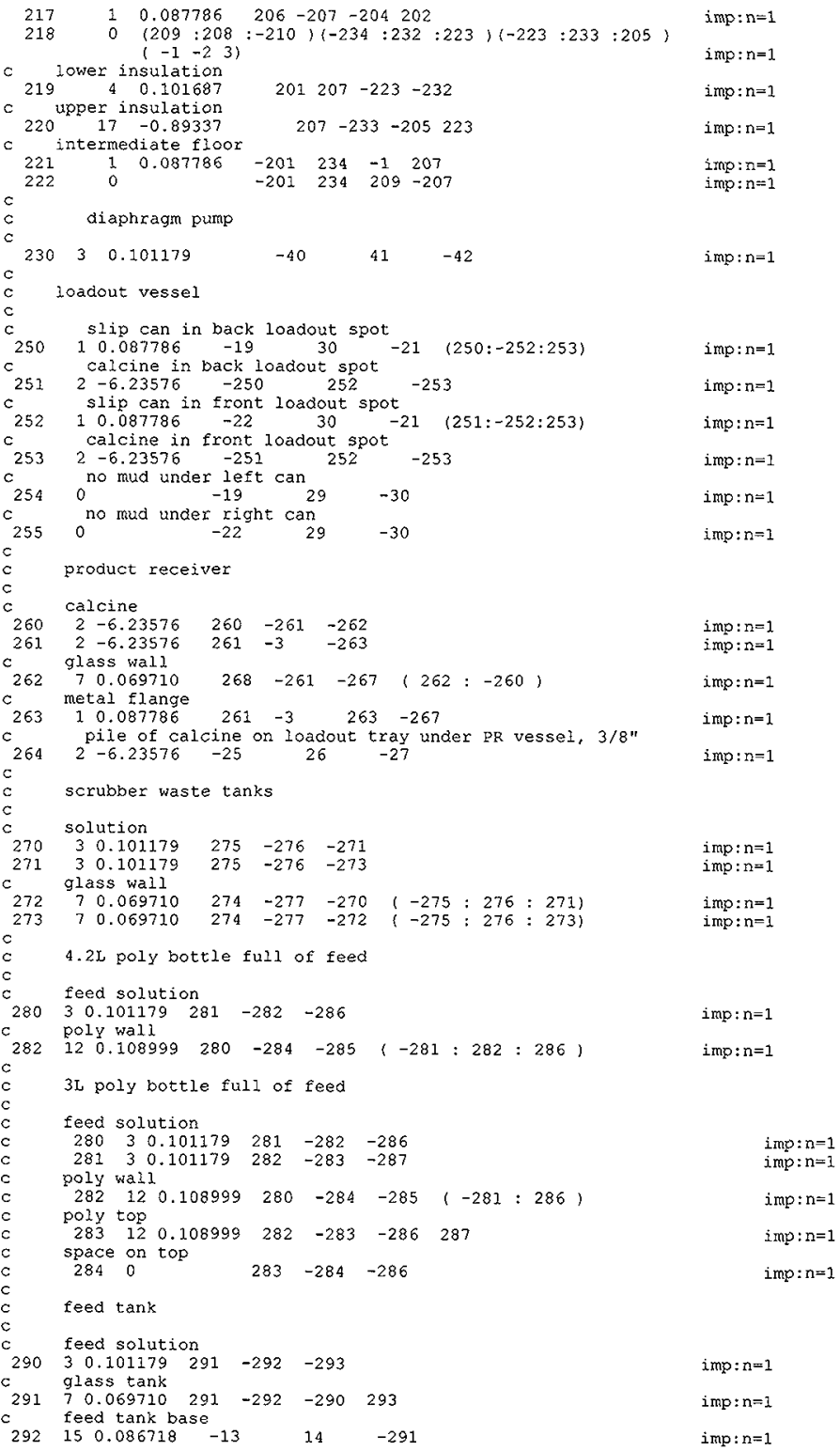


HNF-3908 Rev. 0

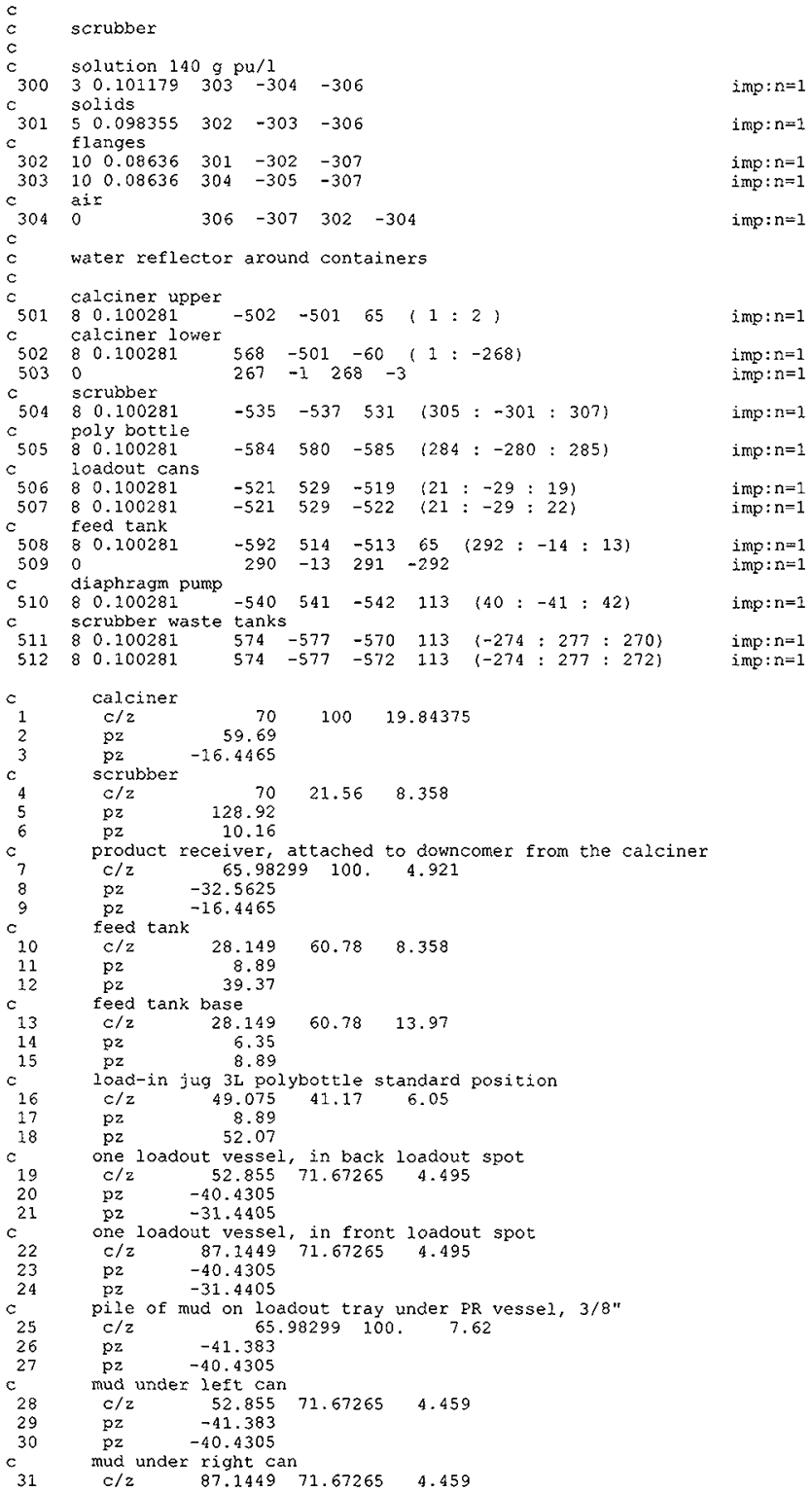


HNF-3908 Rev. 0

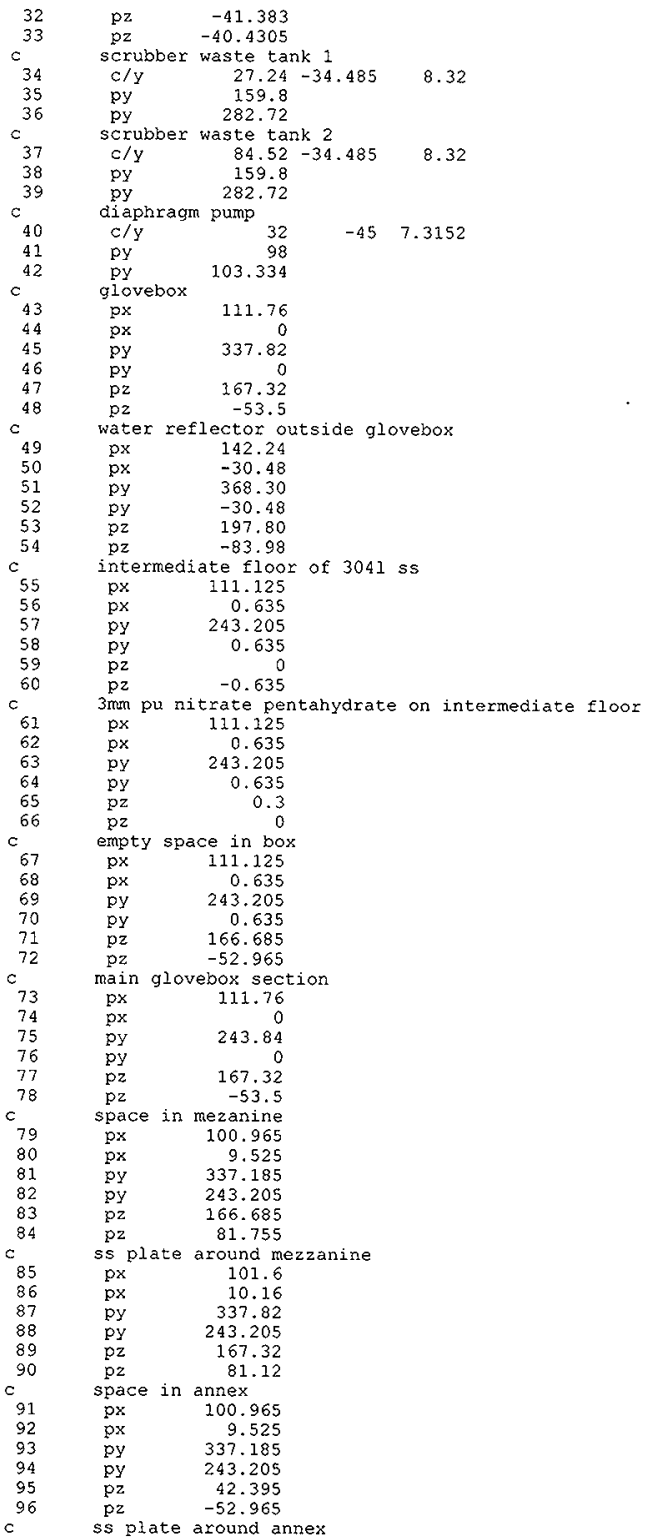


HNF-3908 Rev. 0

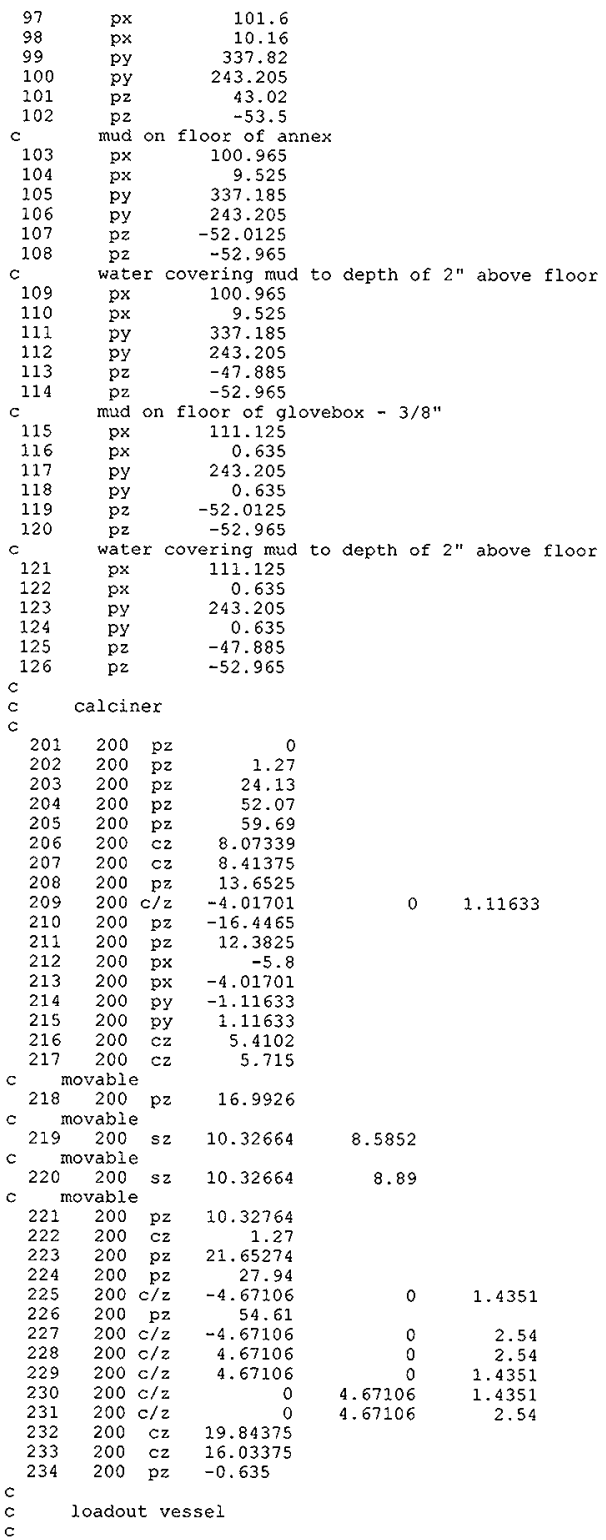


HNF-3908 Rev. 0

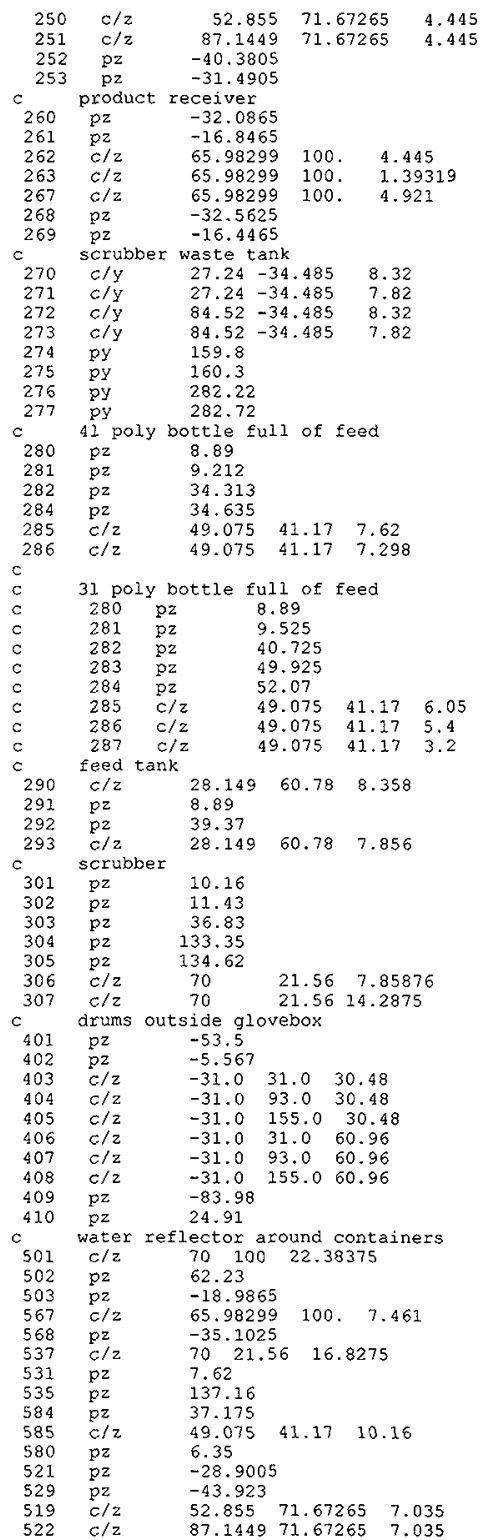


HNF-3908 Rev. 0

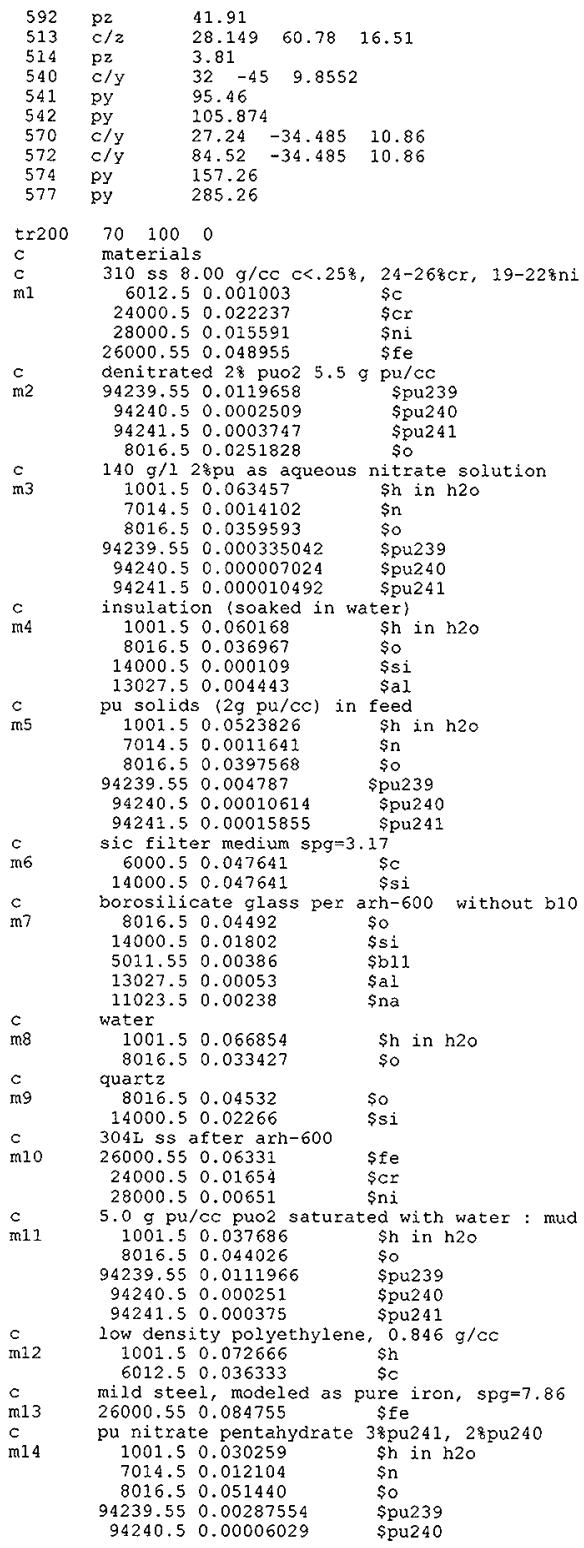


HNF-3908 Rev. 0

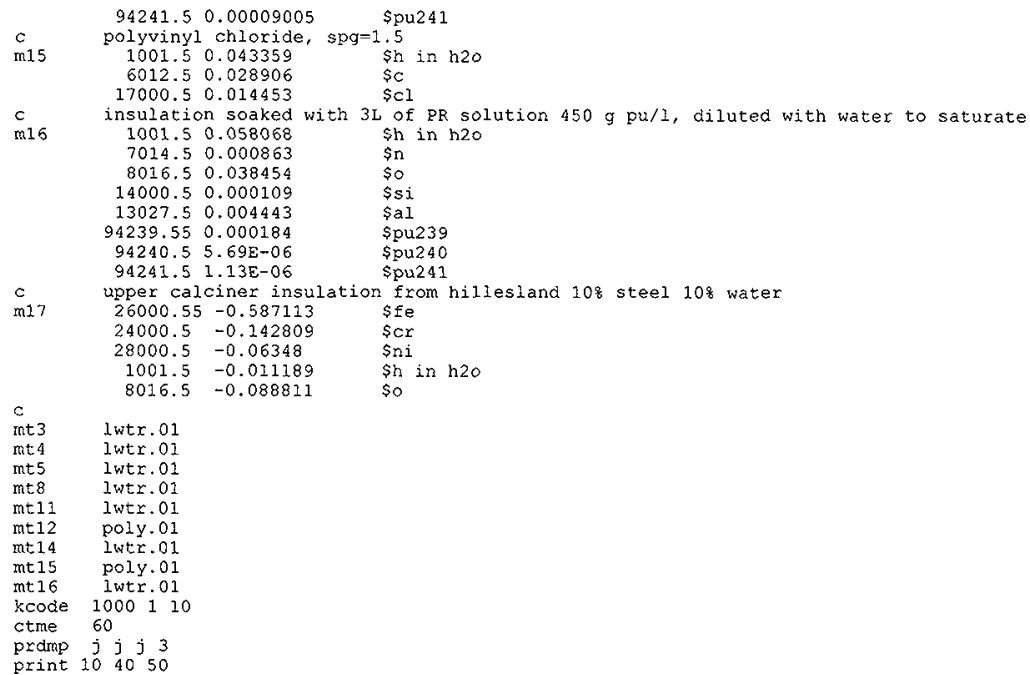


HNF-3908 Rev. 0

\section{diff inpgc.txt inpgeno.txt}

$1 \mathrm{cl}$

< calciner glovebox 188-1, 1" water around all contajners and vessels, 5.5 9 pu/cc, no blo $---$ $>$ calciner glovebox 188-1, no 1 " water around all containers and vesseis, $5.5 \mathrm{~g}$ pu/cc, no bio $241 \subset 241$

$<501 \quad 80.100281 \quad-502-501 \quad 65 \quad\left(\begin{array}{llll}1 & 0\end{array}\right.$

imp: $n=1$

$>\quad 5010 \quad-502 \quad-501 \quad 65 \quad(1: 2)$

2430243

$<\begin{array}{lllllll}502 & 8 & 0.100281 \quad 568 & -501 & -60 & (1:-268)\end{array}$

$---$

$>5020 \quad 568-501-60 \quad(1:-268)$

$246 \mathrm{c} 246$

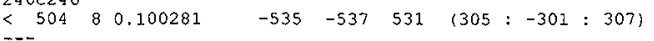

$>504 \quad 0 \quad-535 \quad-537 \quad 531 \quad(305:-301: 307)$

$248 c 248$

$<50580.100281 \quad-584580-585 \quad(284:-280: 285)$

$-$

$>5050$
$250,251 c 250,251$

$<506 \quad 80.100281$

$580-585 \quad(284:-280: 285)$

$<50780.100281$

$\begin{array}{llll}-521 & 529 & -519 \quad(21:-29: 19)\end{array}$

$\begin{array}{lll}-521 & 529 & -522 \quad(21:-29: 22)\end{array}$

$>5060$

$>\quad 5060$

$-521$

$529-519(21:-29: 19)$

$253 \mathrm{c} 253$

$<50880.100281$

$529-522(21:-29: 22)$

$\begin{array}{lllll}-592 & 514 & -513 \quad 65 \quad(292:-14: 13)\end{array}$

$>5080$

$-592$

2560256

$<51080.100281$

$514-513 \quad 65 \quad(292:-14: 13)$

$\begin{array}{lllll}-540 & 541 & -542 & 113(40:-41: 42)\end{array}$

$>510 \quad 0$

$-540$

$258,259 c 258,259$

$<51180.100281$

$541-542 \quad 113 \quad(40:-41: 42)$

$574-577$

570

$574-577$

570113

$3(-274: 277: 270)$

51280.100281

$---$

$>5110$

$574-577$

$-577-570$

113

$(-274: 277: 270)$

$\begin{array}{lllll}574 & -577 & -572 & 113 & (-274: 277: 272)\end{array}$

$: n=1$

imp: $n=1$

imp: $n=1$

i $\operatorname{mp}: n=1$

$i m p: n=1$

imp: $n=1$

i. $m p: n=$ ?

imp: $n=1$

imp: $n=1$

imp: $n=1$

i mp: $n=1$

$i m p: n=1$

imp: $n=1$

imp: $n=1$

imp: $n=1$

imp: $\mathrm{n}=1$ 
HNF-3908 Rev. 0

\section{diff inpgc.txt inpge $3 p$.txt}

\section{1 a2}

$>c$

$25 c 26$

$<c$

$>\mathrm{C}$

$50,51051,53$

three 4.2 l polybottles outside glovebox

borosilicate glass wall

$<50$

glass wall

$>20$
$>$

$>\mathrm{C}$

$511,520 \mathrm{c527}, 542$

$<401 \mathrm{pz}-53.5$

$<402$ p2 -5.567

$<\begin{array}{lllll}403 \quad \mathrm{c} / \mathrm{z} & -31.0 & 31.0 & 30.48\end{array}$

$<404 \mathrm{c} / \mathrm{z} \quad-31.0 \quad 93.0 \quad 30.48$

$<\begin{array}{lllll}405 \mathrm{c} / \mathrm{z} & -31.0 & 155.0 & 30.48\end{array}$

$<406 \mathrm{c} / \mathrm{z} \quad-31.0 \quad 31.060 .96$

$<407 \mathrm{c} / \mathrm{z} \quad-31.0 \quad 93.0 \quad 60.96$

$<\begin{array}{lll}408 \mathrm{c} / \mathrm{z} & -31.0 & 155.060 .96\end{array}$

$\begin{array}{lll}409 \mathrm{pz} & -83.98\end{array}$

\begin{tabular}{l}
$410 \mathrm{pz} \quad 24.91$ \\
\hline
\end{tabular}

-.-.

$\begin{array}{lll}400 \mathrm{pz} & 11.5795\end{array}$

$\begin{array}{lll}401 & \mathrm{pz} & 11.2575\end{array}$

$402 \mathrm{pz} \quad 37.0025$

$403 \mathrm{pz} \quad 36.6805$

404 pz -19.2225

$\begin{array}{lll}405 & \mathrm{pz} & 67.4825\end{array}$

$\begin{array}{lllll}406 & c / z & 70 & -7.72 & 7.298\end{array}$

$\begin{array}{lllll}407 \quad c / z & -7.72 & 60.78 & 7.298\end{array}$

$\begin{array}{lllll}408 \mathrm{c} / \mathrm{z} & 119.48 & 100.0 & 7.298\end{array}$

$\begin{array}{lllll}409 \mathrm{c} / \mathrm{z} & 70 & -7.72 & 7.62\end{array}$

$\begin{array}{lllll}410 & \mathrm{c} / 2 & -7.72 & 60.78 & 7.62\end{array}$

$\begin{array}{lllll}411 \mathrm{c} / 2 & 119.48 & 100.0 & 7.62\end{array}$

$\begin{array}{lllll}412 \mathrm{c} / \mathrm{z} & 70 & -7.72 & 38.10\end{array}$

$\begin{array}{lllll}413 \quad \mathrm{c} / z & -7.72 & 60.78 & 38.10\end{array}$

$414 \mathrm{c} / \mathrm{z} \quad 119.48100 .0 \quad 38.10$ 


\section{diff inpgc.txt inpgc3p450.txt}

$1 \mathrm{c} 1,2$

$<$ calciner glovebox 188-1, $1^{\prime \prime}$ water around all containers and vessels, $5.5 \mathrm{~g}$ pu/cc, no blo -

$>$ calciner glovebox 188-1, 1" water around all, $5.5 \mathrm{~g}$ pu/cc, 3-3L polybottles, no blo

$>\mathrm{c}$

3-3L polybottles Eilled with $450 \mathrm{~g}$ pu/1 solution outside glovebox

$50,51,51,55$

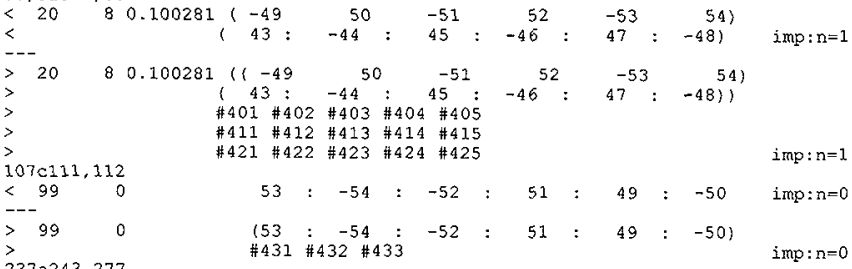

$237 \mathrm{a} 243,277$

$\# 431 \# 432 \# 433 \quad$ imp: $n=0$

$>c$ three $3 \mathrm{~L}$ polybottles with $450 \mathrm{~g}$ pu/L solution outside glovebox

c

feed solution

$\begin{array}{llllll}401 & 18 & -1.75405 & 481 & -482 & -486\end{array}$

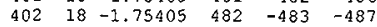

$\operatorname{imp}: n=1$

c poly wall

$\begin{array}{lllllll}403 & 12 & -0.96 \quad 480 & -484 & -485 \quad(-481: 486)\end{array}$

$\operatorname{imp}: n=1$

c poly top

$\begin{array}{lllllll}404 & 12 & -0.96 & 482 & -483 & -486 & 487\end{array}$

$\operatorname{imp}: n=1$

C space on top

405 feed solution

imp: $n=1$

$412 \quad 18-1.75405$

$483-484-486$

imp: $n=1$

c poly wall

$413 \quad 12-0.96$

$482-483-490$

$i m p: n=1$

imp: $n=1$

poly top

$41412-0.96$

$480-484-488(-481: 489)$

imp $: n=1$

c space on top

415 feed solution

$\begin{array}{llllll}421 & 18 & -1.75405 & 481 & -482 & -492\end{array}$

$\begin{array}{llll}482 & -483 & -489 & 490\end{array}$

imp: $n=1$

$i m p: n=1$

$\begin{array}{lll}422 & 18-1.75405\end{array}$

c poly wall

$423 \quad 12-0.96$

c poly top

$42412-0.96$
space on top

C space on top

c water reflector

$43180.100281 \quad 998-499(((485):-480: 484)(-495))-52$

$43280.100281498-499(((488):-480: 484)(-496))-50$

$\begin{array}{llllll}433 & 8 & 0.100281 & 498 & -499 & ((491):-480: 484)(-497)\end{array} 49$

$\mathrm{C}$

$510,520 c 550,570$

$<\mathrm{c}$ drums outside glovebox

$<401$ pz -53.5

$<\begin{array}{lll}402 & \mathrm{pz} & -5.567\end{array}$

$<403 \quad c / 2 \quad-31.0 \quad 31.0 \quad 30.48$

$<404 \quad \mathrm{c} / 2 \quad-31.0 \quad 93.0 \quad 30.48$

$\begin{array}{llll}405 \mathrm{c} / \mathrm{z} & -31.0 & 155.0 & 30.48\end{array}$

$<\begin{array}{lllll}406 & \mathrm{c} / \mathrm{z} & -31.0 & 31.0 & 60.96\end{array}$

$\begin{array}{lllll}407 \mathrm{c} / \mathrm{z} & -31.0 & 93.0 & 60.96\end{array}$

$\begin{array}{lllll}408 \mathrm{c} / \mathrm{z} & -31.0 & 155.0 & 60.96\end{array}$

$\begin{array}{lll}409 & \text { pz } & -83.98\end{array}$

410 pz 24.91

$>c$

480

481

482

483

$>484$

485

31 poly bottles full of feed outside glovebox

$\mathrm{pz} \quad 8.89$

pz 9.525

pz $\quad 40.725$

p2 49.925

p2 $\quad 52.07$

$\mathrm{c} / \mathrm{z} \quad 70$

$\begin{array}{ll}-7.72 & 6.05\end{array}$

$>486$

$c / z$

70

$-7.72 \quad 5.4$ 
HNF-3908 Rev. 0

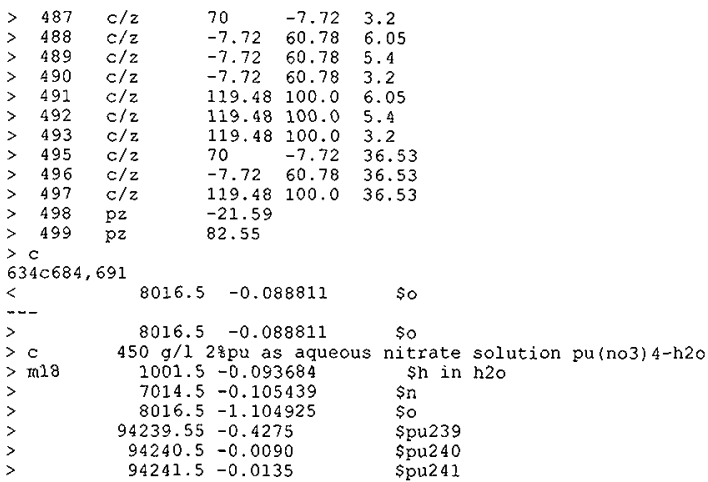




\section{HNF-3908 Rev. 0}

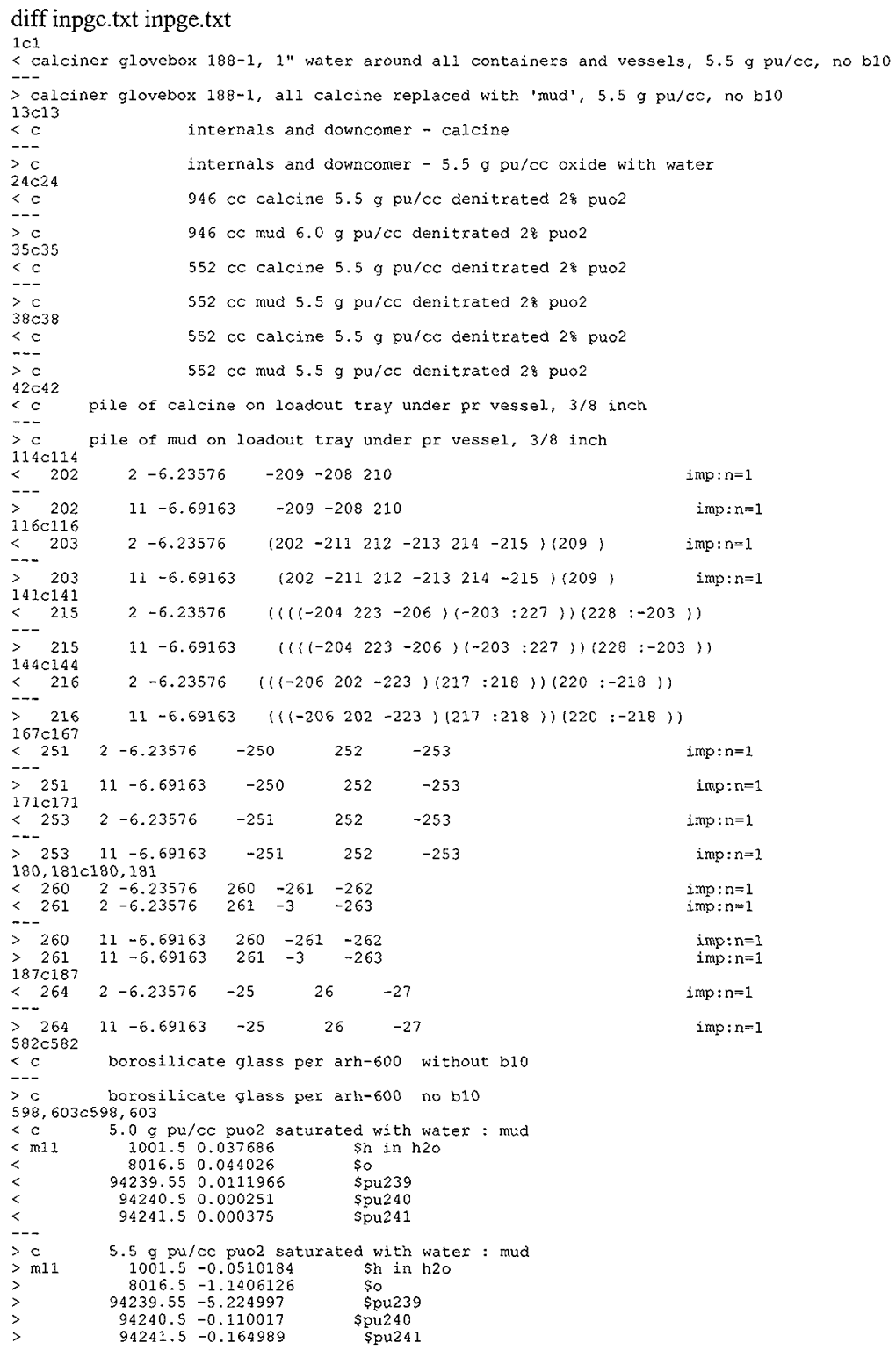


HNF-3908 Rev. 0

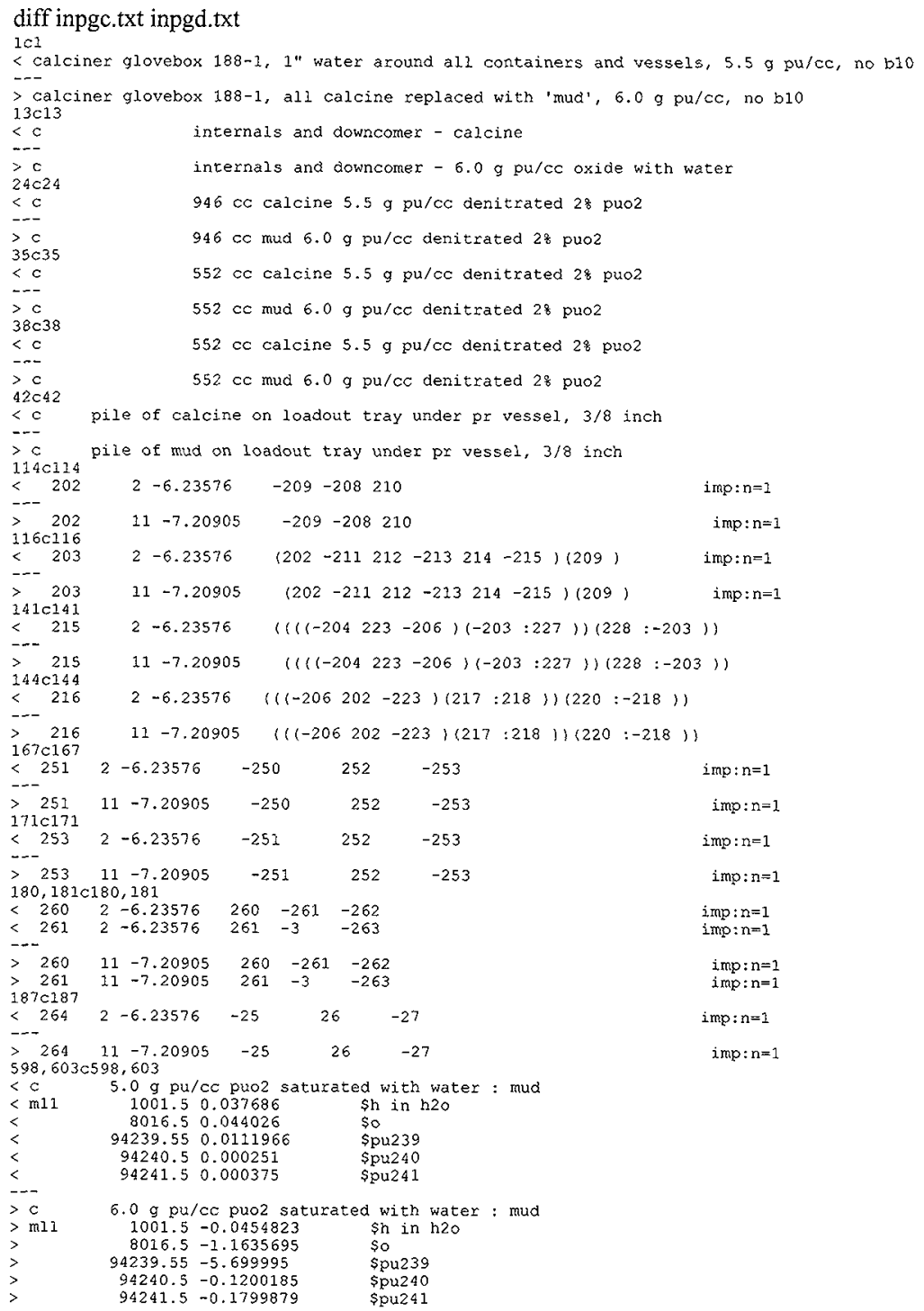


HNF-3908 Rev. 0

This page intentionally left blank. 
HNF-3908 Rev. 0

APPENDIX D. CRITICALITY HAZARDS IDENTIFICATION AND ASSESSMENT

D-1 
HNF-3908 Rev. 0

This page intentionally left blank 
HNF-3908 Rev. 0

\section{Criticality Hazards Identification and Assessment}

\section{Hazards Identification Technique}

The PFP Lab Denitrating Calciner operation has been analyzed using a technique that is a modified combination of the Hazard and Operability (HazOp) study technique and the What-If technique. The goal of the study is the identify deviations from the planned transport operation. The deviations of interest pose a challenge to criticality safety.

In a $\mathrm{HazO}$, an interdisciplinary team uses a creative, systematic approach to identify hazard and operability deviations that could lead to undesirable consequences. Because the criticality safety concerns usually arise from deviations from the process design, an experienced team leader systematically guides the team through the plant design. A fixed set of words (termed "guide words") is applied at specific points or "study nodes" in the plant design and combined with specific process parameters or activities to identify potential deviations from the intended operation. Process parameters that may be examined include flow, temperature, pressure, viscosity, composition, phase, level, addition, reaction, maintenance, testing, instrumentation, and sampling. Guide words (and their meanings) include the following:

"No/none" is the negation of the design or activity intent

"More" is a quantitative increase

"Less" is a quantitative decrease

"As well as"is a qualitative increase

"Part of" is a qualitative decrease

"Reverse" is the logical opposite of the intent

"Other than" is a complete substitution

The What-If analysis can be used to analyze external events, natural phenomena, and potential common-cause failures. The What-If analysis is a brainstorming approach in which a group of experienced personnel familiar with the process or activity ask questions or voice concerns about possible undesired events. It is not as inherently structured as some other techniques (e.g., HazOp analysis). Instead, it requires the analyst(s) to adapt the basic concept to the specific application.

The What-If analysis encourages the hazard analysis team to think of questions that begin with "what if". However, any process safety concern can be voiced even if the concern is not phrased as a question. Usually, a scribe records all questions on a chart pad, marking board, or computer to allow feedback to participants. The questions are then divided into specific areas of investigation (usually related to consequences of interest), such as electrical safety, fire protection, or personnel safety. Each area is subsequently addressed by a team of knowledgeable members. The questions are formulated on the basis of experience and are applied to existing drawings and process descriptions. For an operating plant, the investigation may include interviews with plant staff not represented on the hazard analysis team.

For the assessment of the vertical calciner operation, the $\mathrm{HazO}$ and What-If techniques were combined. For each discrete step in the activity, the team considered the what-if question that was formulated when the guide word was combined with the step. Only challenges to criticality safety were considered. An example of the technique is the guide word "More" associated with loading the carrier 
HNF-3908 Rev. 0

to generate the question what-if there is "More material in can - overbatch". All of the guide words were applied to each activity step to do a complete assessment of the operation. Only rational deviations were recorded.

\section{Operation Analyzed}

The operation analyzed was the sequence of activities for PFP Lab Denitrating Calciner operation. The operation was analyzed as a two phase operation. The first phase was the equipment checkout phase. This phase, in general terms consists of a partial disassembly of the calciner to test controls, heater and examine mechanical components. The product receiver end is then set to an operational configuration. The calciner is started up by starting vacuum, air, denitration heaters and agitator and starting the feed solution pump. With these elements of the process operating, a batch of uncontaminated acid solution is run through the process to confirm operability. The process is shutdown and the scrubber tanks are sampled and drained.

The second phase follows with processing of Plutonium solution. PR can drums are first brought into the room. PR cans are moved into the glovebox. Solution is loaded into the feed tank and the process is run in the same manner described in phase one operation. The product is removed from the product recovery pot and transferred to a product recovery can. The product recovery can is removed from the glovebox. After all of the Plutonium solution is processed, the final step is to sample the scrubber tanks and drain.

The specific operational steps and their order of consideration for each phase are recorded in the What-If/HazOp Worksheet section.

\section{Analysis Record}

The analysis was recorded in tabular form and has a five column format. Column 1, "Item \#", provides a unique number for each deviation. It corresponds to a deviation in the PFP Vertical Denitration Calciner operation. Column 2, "What-If", is the "what-if" question that stimulated the team brainstorming process to identify the hazard or consequence of the deviation. Column 3 , "Hazard/Consequences" is the consequence of potential hazard related to criticality safety that was identified by the team. Column 4, "Safeguard" is the basis that the deviation is within allowable criticality safety guidelines. Column 5, "Comments" identifies either the analysis or basis supporting the safeguard. The complete analysis record is contained in Table D-1.

Table 4 in Section 4.0 is the record of the analysis for this CSER, on the acid feed test only. 


\begin{tabular}{|c|c|c|c|c|}
\hline \multicolumn{5}{|c|}{$\begin{array}{l}\text { Table D-1. "Assessment of "PFP Lab Denitrating Calciner." } \\
\text { Activity Assessment Team:Jim Compton, Maria Shaw, Warren Wittekind, Ed Miller, } \\
\text { Ken Dobbin, and Dennis Clapp } \\
\text { Assessment Conducted January 16, } 1999\end{array}$} \\
\hline Item \# & What If & Hazard/Consequences & Safeguard & Comments \\
\hline 1 & $\begin{array}{l}\text { enough material has } \\
\text { agglomerated on filter } \\
\text { surfaces and/or top plate } \\
\text { itself to create a } \\
\text { criticality concern if it } \\
\text { fell into } 6 \text { " diameter } \\
\text { portion of chamber? }\end{array}$ & $\begin{array}{l}\text { potential criticality } \\
\text { concern }\end{array}$ & & \\
\hline 2 & $\begin{array}{l}\text { product receiver tube is } \\
\text { placed in the extreme } \\
\text { "up" position? }\end{array}$ & $\begin{array}{l}\text { calciner is filled with } \\
\text { Pu powder }\end{array}$ & & \\
\hline 3 & $\begin{array}{l}\text { product receiver tube is } \\
\text { removed? }\end{array}$ & $\begin{array}{l}\text { Pu powder runs out } \\
\text { and build powder pile } \\
\text { on product tray }\end{array}$ & & \\
\hline 4 & $\begin{array}{l}\text { polyethylene tube is } \\
\text { substituted for metal } \\
\text { tube? }\end{array}$ & $\begin{array}{l}\text { Consequences - } \\
\text { potential criticality } \\
\text { concern }\end{array}$ & & $\begin{array}{l}\text { Note: not } \\
\text { considered credible }\end{array}$ \\
\hline 5 & $\begin{array}{l}\text { valve is operated at the } \\
\text { wrong time? }\end{array}$ & $\begin{array}{l}\text { A. Fill calciner with } \\
\text { Pu if closed when } \\
\text { calcining. } \\
\text { B. Spill Pu onto } \\
\text { product shelf and floor } \\
\text { if opened and product } \\
\text { collection pot is not in } \\
\text { place }\end{array}$ & & \\
\hline 6 & $\begin{array}{l}\text { product collection pot } \\
\text { breaks while operating } \\
\text { or filled? }\end{array}$ & $\begin{array}{l}\text { Pu powder spills on } \\
\text { product shelf/floor - } \\
\text { potential criticality } \\
\text { concern }\end{array}$ & & \\
\hline 7 & $\begin{array}{l}\text { spill of clean acid is } \\
\text { spilled on main level } \\
\text { floor? }\end{array}$ & $\begin{array}{l}\text { if enough is spilled, it } \\
\text { will run down to } \\
\text { basement floor with } \\
\text { entrained } \mathrm{Pu}\end{array}$ & & \\
\hline 8 & $\begin{array}{l}\text { acid bottle contents is } \\
\text { taken too close to } \\
\text { calciner body? }\end{array}$ & $\begin{array}{l}\text { increased reflection - } \\
\text { potential criticality } \\
\text { concern }\end{array}$ & & \\
\hline
\end{tabular}


HNF-3908 Rev. 0

\begin{tabular}{|c|l|l|l|l||}
\hline \multicolumn{5}{|c|}{ Table D-1. "Assessment of "PFP Lab Denitrating Calciner." } \\
Activity Assessment Team:Jim Compton, Maria Shaw, Warren Wittekind, Ed Miller, \\
Ken Dobbin, and Dennis Clapp
\end{tabular}




\begin{tabular}{|c|c|c|c|c|}
\hline \multicolumn{5}{|c|}{$\begin{array}{l}\text { Table D-1, "Assessment of "PFP Lab Denitrating Calciner." } \\
\text { Activity Assessment Team:Jim Compton, Maria Shaw, Warren Wittekind, Ed Miller, } \\
\text { Assessment Conducted January 16,1999 }\end{array}$} \\
\hline Item \# & What If & Hazard/Consequences & Safeguard & Comments \\
\hline 16 & $\begin{array}{l}\text { more liquid volume than } \\
\text { heaters can handle? }\end{array}$ & $\begin{array}{l}\text { A. flooding calciner } \\
\text { with acid solution and } \\
\text { increased moderation - } \\
\text { potential criticality } \\
\text { concern } \\
\text { B. overflow } \\
\text { production collection } \\
\text { pot } \\
\text { C. Pu cloud in } \\
\text { glovebox (too much } \\
\text { feed evaporating at } \\
\text { once with a steam } \\
\text { pressure buildup) }\end{array}$ & & \\
\hline 17 & $\begin{array}{l}\text { Pu concentration in } \\
\text { scrub solution is too } \\
\text { high? }\end{array}$ & $\begin{array}{l}\text { potential criticality } \\
\text { concern of Pu-water } \\
\text { mixture }\end{array}$ & & \\
\hline 18 & $\begin{array}{l}\text { there are too many PR } \\
\text { can drums in the room? }\end{array}$ & $\begin{array}{l}\text { potential criticality } \\
\text { concern }\end{array}$ & & \\
\hline 19 & $\begin{array}{l}\text { wrong drum ( } 8 \text { liter } P R \\
\text { can) are brought into the } \\
\text { room? }\end{array}$ & $\begin{array}{l}\text { potential criticality } \\
\text { concern }\end{array}$ & & \\
\hline 20 & $\begin{array}{l}55 \text { gallon waste drum is } \\
\text { brought into the room? }\end{array}$ & $\begin{array}{l}\text { potential criticality } \\
\text { concern }\end{array}$ & & \\
\hline 21 & $\begin{array}{l}10 \text { liter type containers } \\
\text { brought into the room? }\end{array}$ & $\begin{array}{l}\text { potential criticality } \\
\text { concern }\end{array}$ & & \\
\hline 22 & $\begin{array}{l}\text { drum spacing is } \\
\text { incorrect? } \\
\text { A. with respect to each } \\
\text { other } \\
\text { B. with respect to } \\
\text { fissile material in the } \\
\text { room } \\
\text { C. with respect to other } \\
\text { fissile material outside } \\
\text { the room (other } \\
\text { room/corridor) }\end{array}$ & $\begin{array}{l}\text { potential criticality } \\
\text { concern }\end{array}$ & & \\
\hline
\end{tabular}




\begin{tabular}{|c|c|c|c|c|}
\hline \multicolumn{5}{|c|}{$\begin{array}{l}\text { Table D-1. Assessment of "PFP Lab Denitrating Calciner." } \\
\text { Activity Assessment Team Jim Compton, Maria Shaw, Warren Wittekind, Ed Miller, } \\
\text { Ken Dobbin, and Dennis Clapp } \\
\text { Assessment Conducted January 16,1999 }\end{array}$} \\
\hline Item \# & What If & Hazard/Consequences & Safeguard & Comments \\
\hline 23 & a 4.2 liter bottle breaks? & $\begin{array}{l}\text { potential criticality } \\
\text { concern }\end{array}$ & & \\
\hline 24 & $\begin{array}{l}\text { a } 4.2 \text { liter bottle } \\
\text { leaks/spills in } \\
\text { glovebox? }\end{array}$ & $\begin{array}{l}\text { potential criticality } \\
\text { concern }\end{array}$ & & \\
\hline 25 & $\begin{array}{l}\text { there is more than } 1 \\
\text { feed poly bottle in } \\
\text { glovebox? }\end{array}$ & $\begin{array}{l}\text { potential criticality } \\
\text { concern }\end{array}$ & & \\
\hline 26 & $\begin{array}{l}\text { the feed poly bottle is in } \\
\text { the wrong location? }\end{array}$ & $\begin{array}{l}\text { potential criticality } \\
\text { concern }\end{array}$ & & \\
\hline 27 & $\begin{array}{l}\text { there is excessive waste } \\
\text { in the glovebox? }\end{array}$ & $\begin{array}{l}\text { increased reflection - } \\
\text { potential criticality } \\
\text { concern }\end{array}$ & & \\
\hline 28 & $\begin{array}{l}\text { the feed tank is } \\
\text { overfilled? }\end{array}$ & $\begin{array}{l}\text { potential overflow/spill } \\
\text { of } 4.2 \text { liter of } \mathrm{Pu} \\
\text { solution }\end{array}$ & & \\
\hline 29 & $\begin{array}{l}\text { calciner is flooded (as a } \\
\text { result of gravity flow or } \\
\text { loss of pump control) } \\
\text { with feed? }\end{array}$ & $\begin{array}{l}\text { potential criticality } \\
\text { concern }\end{array}$ & & \\
\hline 30 & $\begin{array}{l}\text { calciner is flooded with } \\
\text { feed (as a result of a } \\
\text { syphon back) from feed } \\
\text { tank? }\end{array}$ & $\begin{array}{l}\text { potential criticality } \\
\text { concern }\end{array}$ & & \\
\hline 31 & $\begin{array}{l}\text { calciner is filled with } \\
\text { feed solution? }\end{array}$ & $\begin{array}{l}\text { potential criticality } \\
\text { concern }\end{array}$ & & \\
\hline 32 & $\begin{array}{l}\text { calciner feed solution } \\
\text { goes to scrubber tanks } \\
\text { and overflows? }\end{array}$ & $\begin{array}{l}\text { potential criticality } \\
\text { concern }\end{array}$ & & \\
\hline 33 & $\begin{array}{l}\text { calciner feed solution } \\
\text { enters scrubber closed } \\
\text { coolant system? }\end{array}$ & $\begin{array}{l}\text { potential criticality } \\
\text { concern }\end{array}$ & & $\begin{array}{l}\text { Note: Concern - } \\
\text { coolant system for } \\
\text { scrubber tank has a } 5 \\
\text { gallon capacity }\end{array}$ \\
\hline
\end{tabular}




\begin{tabular}{|c|c|c|c|c|}
\hline & $\begin{array}{l}\text { Table D-1 "A } \\
\text { Activity Assessment Team } \\
\text { Asse }\end{array}$ & $\begin{array}{l}\text { sessment of "PFP Lab D } \\
\text { im Compton, Maria Sha } \\
\text { cen Dobbin, and Dennis } \\
\text { sment Conducted Januar }\end{array}$ & $\begin{array}{l}\text { trating Calc } \\
\text { Warren Wit } \\
\text { pp } \quad \\
6,1999\end{array}$ & Ed Miller, \\
\hline Item \#: & What If & Hazard/Consequences & Safeguard & Comments \\
\hline 34 & $\begin{array}{l}\text { the vacuum trap is filled } \\
\text { with calciner feed } \\
\text { solution? }\end{array}$ & $\begin{array}{l}\text { potential criticality } \\
\text { concern }\end{array}$ & & \\
\hline 35 & $\begin{array}{l}\text { water is in the calciner } \\
\text { body insulation? }\end{array}$ & $\begin{array}{l}\text { increased reflectivity - } \\
\text { potential criticality } \\
\text { concern }\end{array}$ & & \\
\hline 36 & $\begin{array}{l}\text { product recovery tube } \\
\text { valve is open when } \\
\text { product collection pot is } \\
\text { emptied? }\end{array}$ & $\begin{array}{l}\text { potential criticality } \\
\text { concern because of } \mathrm{Pu} \\
\text { accumulation on shelf }\end{array}$ & & \\
\hline 37 & $\begin{array}{l}\text { there are too many } \\
\text { product cans are on } \\
\text { shelf? }\end{array}$ & $\begin{array}{l}\text { potential criticality } \\
\text { concern }\end{array}$ & & \\
\hline 38 & $\begin{array}{l}\text { there are too many } \\
\text { product cans are in the } \\
\text { basement? }\end{array}$ & $\begin{array}{l}\text { potential criticality } \\
\text { concern }\end{array}$ & & \\
\hline 39 & $\begin{array}{l}\text { water is sprayed onto } \\
\text { product accumulation } \\
\text { on shelf? }\end{array}$ & $\begin{array}{l}\text { potential criticality } \\
\text { concern }\end{array}$ & & \\
\hline 40 & $\begin{array}{l}\text { there are more than } 1 \\
\text { full product collection } \\
\text { pots? }\end{array}$ & $\begin{array}{l}\text { potential criticality } \\
\text { concern }\end{array}$ & & \\
\hline 41 & $\begin{array}{l}\text { all available liquid is on } \\
\text { basement floor up to } \\
\text { height of criticality } \\
\text { drain? }\end{array}$ & $\begin{array}{l}\text { increased reflection - } \\
\text { potential criticality } \\
\text { concern }\end{array}$ & & \\
\hline 42 & $\begin{array}{l}\text { a product can is } \\
\text { inappropriately spaced? }\end{array}$ & $\begin{array}{l}\text { potential criticality } \\
\text { concern }\end{array}$ & & \\
\hline 43 & $\begin{array}{l}\text { there are too many } \\
\text { product cans are in } \\
\text { room? }\end{array}$ & $\begin{array}{l}\text { potential criticality } \\
\text { concern }\end{array}$ & & \\
\hline 44 & $\begin{array}{l}\text { there is full reflections } \\
\text { of product cans? }\end{array}$ & $\begin{array}{l}\text { potential criticality } \\
\text { concern }\end{array}$ & & \\
\hline
\end{tabular}




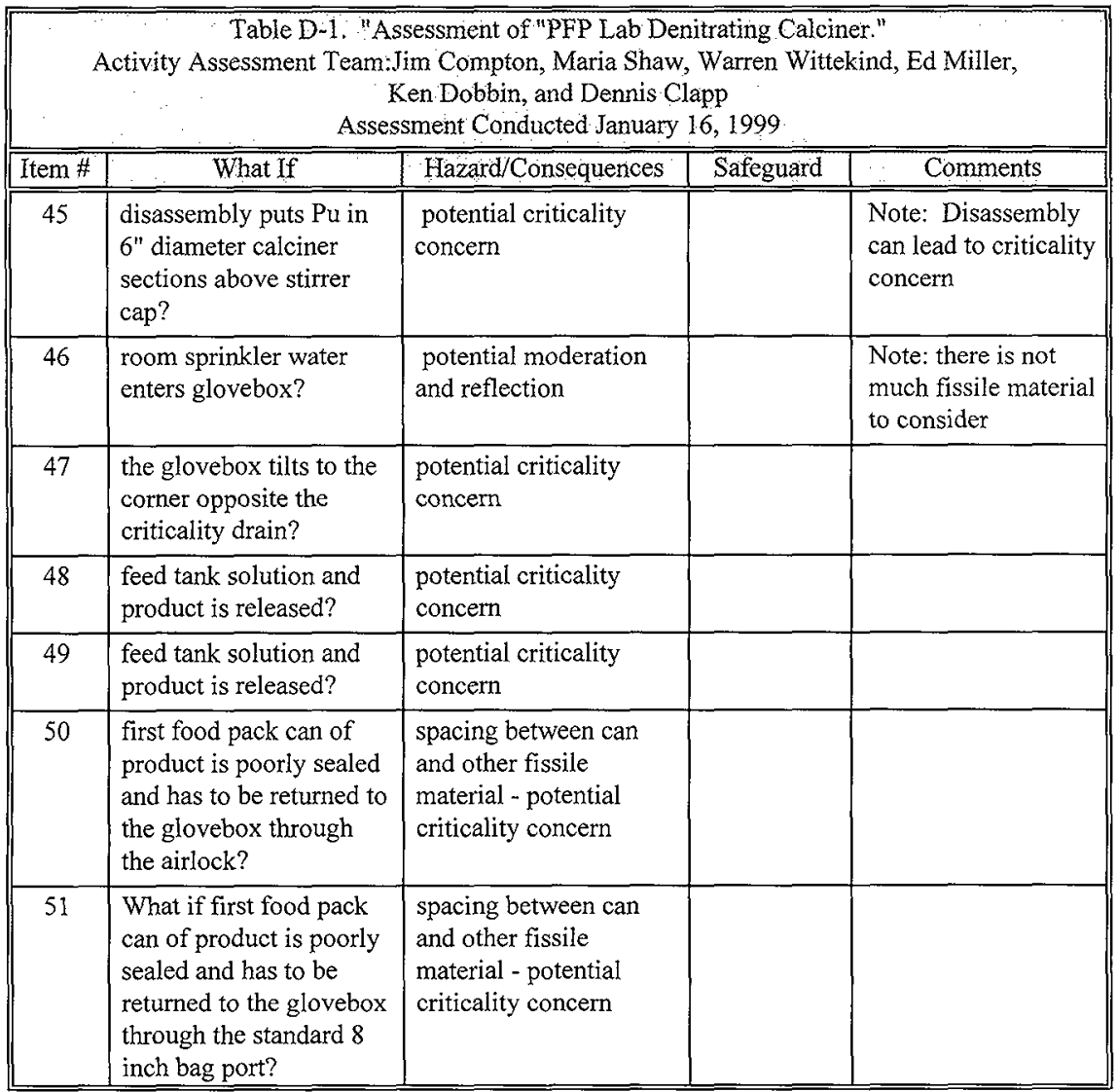

\section{Analysis Team}

The analysis was done on January 16, 1999. The analysis team included Jim Compton, Ken Dobbin, Maria Shaw, Edward Miller, Warren Wittekind and Dennis Clapp. Dennis Clapp was the team leader and scribe. A brief resume of each team member is included.

\section{Team Resumes}

Warren D. Wittekind - Flour Daniel Northwest - Process/Specialty Engineer - Nuclear Engineering and Safety Analysis 
Dr. Wittekind has been working at the Hanford Site since 1978 in criticality safety, nuclear engineering, equipment development, numerical modeling, numerical analysis and related fields. He has worked on Plutonium Finishing Plant (PFP) criticality safety since 1996 and previous to that on storage basin criticality safety for $\mathrm{N}$ Reactor fuel. He has worked, during temporary off-site assignments, on glovebox criticality safety for plutonium at Rocky Flats, analytical laboratory criticality safety for low enriched uranium (LEU) at Portsmouth Gaseous Diffusion Plant, and reactor fuel production line criticality safety for high enriched uranium (HEU) at Nuclear Fuel Services. Mr. Wittekind has an advanced degree in Physics and subsequent Nuclear Engineering course work.

\section{Edward M. Miller - Fluor Daniel Northwest - Senior Process/Speciality Engineer}

Mr. Miller has eight years experience as a criticality specialist at the Hanford Site. He has worked on Plutonium Finishing Plant (PFP) criticality safety during that period and on other facilities criticality safety at Hanford and other DOE sites. He has toured PFP numerous times for audits and to investigate plant equipment for analyses. His job specific criticality training has been augmented by participation in a criticality conference about once a year. Mr. Miller has an undergraduate degree in physics and an masters degree in nuclear engineering.

Jim Compton - Babcock and Wilcox Hanford - Plutonium Finishing Plant Laboratory

Mr. Compton has worked in the development laboratory within PFP for the last 22 years. He has worked on development and testing of the PUREX prototype calciner and is the most experienced of the people who have run the prototype vertical calciner. He also assisted with design and installation of the prototype vertical calciner. He holds a B.S. in chemical engineering (1975) and a Professional Engineer's license.

\section{Dennis A. Clapp - Fluor Daniel Northwest - Senior Process/Speciality Engineer}

Mr. Clapp is currently employed in the Safety Analysis and Risk Assessment section of the Speciality Engineering group of Fluor Daniel Northwest. He has been at the Hanford Site for 22 years. He has experience in nuclear power plant construction as a construction contract administrator, field engineer, design engineer, and construction engineer. His Hanford Operations Contractor work experience includes conceptual design, Hanford Waste Vitrification Plant project design oversight, and safety analysis. His last 13 years have been in safety analysis. Mr. Clapp is certified by the Process Safety Institute as a Hazards Assessment Team Leader using the HazOp and Checklist/What If techniques. His education is a Bachelor of Science in Chemical Engineering.

Maria E. Shaw - B\&W Federal Services - Nuclear Criticality Safety Representative - Nuclear Engineer

Ms. Shaw has worked as an engineer since 1991 and has been at the Hanford site since 1998. She has worked at the Plutonium Finishing Plant as a criticality safety representative and is plant certified as a Criticality Safety Representative. She has worked on the PFP thermal stabilization project. Ms. Shaw holds a B.S. in math from Idaho State and an M.S. in Chemistry from Univ. of 
Idaho. Prior to Hanford, she worked in the criticality safety field at Idaho National Engineering Laboratory and at the Naval Nuclear Fuel Facility (Lynchburg, VA.)

Ken Dobbin - Flour Daniel Northwest - Senior Process/Speciality Engineer

Mr. Dobbin has 24 years experience as a nuclear engineer analyzing reactor physics and fuel management with 4 years experience in criticality safety. He is currently the Criticality Safety Engineer at the Plutonium Finishing Plant, qualifying per PFP Criticality Safety Engineer Course \#202214, and has 10 months experience on PFP systems. During his PFP tenure, he contributed criticality safety expertise for the successful completion of an Operational Readiness Review to begin thermal stabilization of plutonium compounds. Mr. Dobbin has both undergraduate and masters degrees in Nuclear Engineering.

\section{What If/HazOp Worksheet}

Equipment Checkout Phase (Phase I)

Step - Partial disassembly of calciner

1. What if enough material has agglomerated on filter surfaces and/or top plate itself to create a criticality concern if it fell into $6^{\prime \prime}$ diameter portion of chamber?

Consequence - potential criticality concern

Step - Open up calciner and test controls, heater, examine the mechanical components.

Activity - Position product receiver tube in the "up" position

Deviation- "no" did not position product receiver tube in the "nominal" operational position

A. tube all the way up

$B$. tube all the removed

Consequences-

A. fill calciner with $P u$

B. Pu powder runs out and builds powder pile on product tray

2. What if product receive tube is placed in the extreme "up" position?

Consequence - calciner is filled with Pu powder

3. What if product receive tube is all the way out?

Consequence - Pu powder runs out and build powder pile on product tray.

4. What if polyethylene tube is substituted for metal tube?

Consequences - criticality concern

Note: not considered credible

Step - Open/close product receiver tube valve.

5. What if valve is operated at the wrong time? 
HNF-3908 Rev. 0

Consequences -

A. Fill calciner with $\mathrm{Pu}$ if closed when calcining.

B. Spill Pu onto product shelf and floor if opened and product collection pot is not in place.

6. What if product collection pot breaks while operating or filled?

Consequences - Pu powder spills on product shelf/floor - potential criticality concern

Step - Transferring clean acid to feed tank location

7. What if spill of clean acid is spilled on main level floor?

Consequences - if enough is spilled, it will run down to basement floor with entrained $\mathrm{Pu}$

Step - Filling feed tank with acid.

8. What if acid bottle contents is taken too close to calciner body?

Consequences - increased reflection - potential criticality concern.

9. What if acid is mistakenly added to calciner through pressure relief port?

Consequences - increasing moderation - potential criticality concern

Step - Startup; vacuum, air, heaters and agitator (possibly concurrently)

10. What if heater only is run?

Consequences - heat may shrink Pu crystals in calciner bed with powder density increase - potential criticality concern.

11. What if agitator is run?

Consequence - comminuted crystals with powder density increase - potential criticality concern

12. What if liquid (of different chemical composition) is added to feed tank?

Consequences - dissolves Pu oxide in calciner

13. What if fissile solution rather than clean acid is added to the calciner feed tank?

Consequences - increased amount of Pu in calciner - potential criticality concern

With air running and calciner filters breached

14. What if $\mathrm{Pu}$ is driven into the scrubber?

Consequences - increasing Pu concentration in scrubber and scrubber system as a whole- potential criticality concern

Step - Open feed tank feed valve

15. What if the feed system leaks?

Consequences - acid solution is spilled to basement 
16. What if more liquid volume than heaters can handle?

Consequences -

A. flooding calciner with acid solution and increased moderation - potential criticality concern

B. overflow production collection pot

C. Pu cloud in glovebox (too much feed evaporating at once with a steam pressure buildup)

Step - Run calciner to see if it working correctly

No problems discernible with this step

Step - Shutdown

No problems discernible with this step

Step - Sample spent scrub solution tanks

No problems discernible with this step

Step - Open scrubber tank drain valves to drain to PFP drain system

17. What if Pu concentration in scrub solution is too high?

Consequence - potential criticality concern of Pu-water mixture

Operation with Pu solution (Phase II)

Step - Bring PR can drums through the door of Room 188

18. What if there are too many PR can drums in the room?

Consequences - potential criticality concern

19. What if wrong drum (8 liter PR can) are brought into the room?

Consequences - potential criticality concern

20. What if 55 gallon waste drum is brought into the room?

Consequences - potential criticality concern

21. What if 10 liter type containers brought into the room?

Consequences - potential criticality concern

22. What if drum spacing is incorrect?

A. with respect to each other

B. with respect to fissile material in the room

C. with respect to other fissile material outside the room (other room/corridor)

Consequences - potential criticality concern

Step - Open PR can drum and move a 4.2 liter bottle

23. What if a 4.2 liter bottle breaks? 
Consequence - potential criticality concern

24. What if a 4.2 liter bottle leaks/spills in glovebox?

Consequence - potential criticality concern

25. What if there is more than 1 feed poly bottle in glovebox?

Consequence - potential criticality concern

26. What if the feed poly bottle is in the wrong location?

Consequence - potential criticality concern

27. What if there is excessive waste in the glovebox?

Consequence - increased reflection - potential criticality concern

Calciner Operation Phase

Step - Fill feed tank

28. What if the feed tank is overfilled?

Consequences - potential overflow/spill of 4.2 liter of $\mathrm{Pu}$ solution

29. What if calciner is flooded (as a result of gravity flow or loss of pump control) with feed? Consequence - potential criticality concern

30. What if calciner is flooded with feed (as a result of a syphon back) from feed tank?

Consequence - potential criticality concern

31. What if calciner is filled with feed solution?

Consequence - potential criticality concern

32. What if calciner feed solution goes to scrubber tanks and overflows?

Consequences - potential criticality concern

33. What if calciner feed solution enters scrubber closed coolant system?

Consequence - potential criticality concern

Note: Concern - coolant system for scrubber tank has a 5 gallon capacity

34. What if the vacuum trap is filled with calciner feed solution?

Consequence - potential criticality concern

35. What if water is in the calciner body insulation?

Consequence - increased reflectivity - potential criticality concern

Step - Product removal

36. What if product recovery tube valve is open when product collection pot is emptied? 
HNF-3908 Rev. 0

Consequence - potential criticality concern because of $\mathrm{Pu}$ accumulation on shelf

37. What if there are too many product cans are on shelf?

Consequence - potential criticality concern

38. What if there are too many product cans are in the basement?

Consequence - potential criticality concern

39. What if water is sprayed onto product accumulation on shelf?

Consequence - potential criticality concern

40. What if there are more than 1 full product collection pots?

Consequence - potential criticality concern

41. What if all available liquid is on basement floor up to height of criticality drain?

Consequence - increased reflection - potential criticality concern

42. What if a product can is inappropriately spaced?

Consequence - potential criticality concern

43. What if there are too many product cans are in room?

Consequence - potential criticality concern

44. What if there is full reflections of product cans?

Consequences - potential criticality concern

45. What if disassembly puts $\mathrm{Pu}$ in 6 "diameter calciner sections above stirrer cap?

Consequences - potential criticality concern

Note: Disassembly can lead to criticality concern

Phase I

Fire Consideration

46. What if room sprinkler water enters glovebox?

Consequence - potential moderation and reflection

Note: there is not much fissile material to consider

Seismic Consideration

47. What if the glovebox tilts to the corner opposite the criticality drain?

Consequence - potential criticality concern

Phase II

Fire Consideration

48. What if feed tank solution and product is released?

D-16 


\section{HNF-3908 Rev. 0}

Consequences - potential criticality concern

Seismic Consideration

49. What if feed tank solution and product is released?

Consequence - potential criticality concern

Potential additional activity of returning poorly sealed food pack to glovebox

50. What if first food pack can of product is poorly sealed and has to be returned to the glovebox through the airlock?

Consequence - spacing between can and other fissile material - potential criticality concern

51. What if first food pack can of product is poorly sealed and has to be returned to the glovebox through the standard 8 inch bag port?

Consequence - spacing between can and other fissile material - potential criticality concern 
HNF-3908 Rev. 0

This page intentionally left blank.

D-18 


\section{APPENDIX E. SEISMIC MCNP CASE INPUTS}

Seismic MCNP case inputs:

pu_hem1.inp Oxide density $0.45 \mathrm{~g} / \mathrm{cm}^{3}$, hemisphere case. .................. E-3

pu_sph0.inp Oxide density $0.45 \mathrm{~g} / \mathrm{cm}^{3}$, sphere case. ................. E-3

pu_sph1.inp Oxide density $1.00 \mathrm{~g} / \mathrm{cm}^{3}$, sphere case. .................... E-4

pu_sph2.inp Oxide density $2.00 \mathrm{~g} / \mathrm{cm}^{3}$, sphere case. .................... E-5

pu_sph3.inp Oxide density $3.00 \mathrm{~g} / \mathrm{cm}^{3}$, sphere case. .................... E-5

pu_sph4.inp Oxide density $4.00 \mathrm{~g} / \mathrm{cm}^{3}$, sphere case $\ldots \ldots \ldots \ldots \ldots \ldots \ldots \ldots$ E-6

pu_sph5.inp Oxide density $5.00 \mathrm{~g} / \mathrm{cm}^{3}$, sphere case. . . . . . . . . . . . . E-7 
HNF-3908 Rev. 0

This page left intentional blank.

\section{E-2}




\section{pu_hem1.inp Oxide density $0.45 \mathrm{~g} / \mathrm{cm}^{3}$, hemisphere case}

message:

Hemisphere, $4500 \mathrm{~g} \mathrm{Pu}, 0.397 \mathrm{~g} \mathrm{Pu} / \mathrm{cm} 3,0.45 \mathrm{~g} \mathrm{Pu} 02 / \mathrm{cm} 3,1.410 \mathrm{~g} / \mathrm{cm} 3$

c -dens $\mathrm{xx}$-xx yy -yy $\mathrm{zz}-\mathrm{zz}$ rr $-\mathrm{rr} \$$ Comments

$\begin{array}{llll}1 & 1 & -1.41076-13 & 3\end{array}$

$\begin{array}{llllll}2 & 2 & -1.000 & 1 & -2 & 3\end{array}$

$\begin{array}{llllll}3 & 2 & -1.000 & -3 & 4 & -2\end{array}$

$40 \quad 2:-4$

1 so 17.55884 \$ scrap hemisphere radius

2 so $42.55884 \quad \$ 25 \mathrm{~cm}$ water reflection

$3 \mathrm{pz} 0.0 \quad \$$ hemisphere plane

$4 \mathrm{pz}-25.0 \quad$ \$ bottom water reflection

mode $\mathrm{n}$

tmp 2.585e-8 2r $\quad \$ 001-002300 \mathrm{~K}$ everywhere $1 \mathrm{j} \quad \$$ outside world

kcode 10001.020500

$\begin{array}{llllll}\text { ksrc } & 0.000 & 0.000 & 7.000 & \$ \text { uranium solution }\end{array}$

$\mathrm{m} 1 \quad 94239.55 \mathrm{c}-0.27009 \quad$ \$ plutonium solution

$94240.50 \mathrm{c}-0.00844$

$94241.50 \mathrm{c}-0.00281$

$1001.50 \mathrm{c}-0.07620$

$8016.50 \mathrm{c}-0.64245$

mt1 lwtr.01t

$\mathrm{m} 2 \quad 1001.50 \mathrm{c} \quad 0.66667 \quad$ \$ reflector water $8016.50 \mathrm{c} \quad 0.33333$

mt2 lwtr.01t $\$ 300 \mathrm{~K}=27 \mathrm{C}=80.6 \mathrm{~F}$

totnu

ctme 480 .

print 304060110126

\section{pu_sph0.inp Oxide density $0.45 \mathrm{~g} / \mathrm{cm}^{3}$, sphere case}

message:

Sphere, $4500 \mathrm{~g} \mathrm{Pu}, 0.397 \mathrm{~g} \mathrm{Pu} / \mathrm{cm} 3,0.45 \mathrm{~g} \mathrm{Pu} 02 / \mathrm{cm} 3,1.410 \mathrm{~g} / \mathrm{cm} 3$

c -dens $\mathrm{xx}-\mathrm{xx}$ yy $-\mathrm{yy} \mathrm{zz}-\mathrm{zz}$ rr $-\mathrm{rr} \$$ Comments

1 l $1-1.41076-1$

$\begin{array}{llllll}2 & 2 & -1.000 & 1 & -2\end{array}$

$30 \quad 2$ imp:n=1 $\$$ fuel inside hemisphere imp: $n=1 \$$ water reflector imp: $n=0 \$$ outside world

1 so 13.93646 \$ scrap hemisphere radius 
HNF-3908 Rev. 0

2 so $38.93646 \quad \$ 25 \mathrm{~cm}$ water reflection

mode $n$

tmp $2.585 \mathrm{e}-8 \quad 2 \mathrm{r} \quad \$ 001-002300 \mathrm{~K}$ everywhere

$1 \mathrm{j} \quad \$$ outside world

kcode 10001.020100

$\begin{array}{lllll}\text { ksrc } & 0.000 & 0.000 & 0.000 & \$ \text { plutonium solution }\end{array}$

m1 $94239.55 \mathrm{c}-0.27009$ \$ plutonium solution

$94240.50 \mathrm{c}-0.00844$

$94241.50 \mathrm{c}-0.00281$

$1001.50 c-0.07620$

$8016.50 \mathrm{e}-0.64245$

$\mathrm{mt} 1$ 1wtr.01t

$\mathrm{m} 2 \quad 1001.50 \mathrm{c} \quad 0.66667 \quad \$$ reflector water

$8016.50 \mathrm{c} \quad 0.33333$

mt2 lwtr.01t $\$ 300 \mathrm{~K}=27 \mathrm{C}=80.6 \mathrm{~F}$

totnu

ctme 480 .

print 304060110126

\section{pu_sph1.inp Oxide density $1.00 \mathrm{~g} / \mathrm{cm}^{3}$, sphere case}

message:

Sphere, $4500 \mathrm{~g} \mathrm{Pu}, 0.882 \mathrm{~g} \mathrm{Pu} / \mathrm{cm} 3,1.00 \mathrm{~g} \mathrm{PuO} 2 / \mathrm{cm} 3,1.913 \mathrm{~g} / \mathrm{cm} 3$

c -dens $\mathrm{xx}-\mathrm{xx}$ yy $-\mathrm{yy} \mathrm{zz}-\mathrm{zz} \mathrm{rr}-\mathrm{rr} \$$ Comments

$1 \quad 1-1.91274-1$

$\begin{array}{llllll}2 & 2 & -1.000 & 1 & -2\end{array}$

$30 \quad 2 \quad$ imp: $n=0$ outside world

1 so 10.67964 \$ scrap hemisphere radius

2 so $35.67964 \$ 25 \mathrm{~cm}$ water reflection

mode $\mathrm{n}$

tmp $2.585 \mathrm{e}-8 \quad 2 \mathrm{r} \quad \$ 001.002300 \mathrm{~K}$ everywhere

$1 \mathrm{j} \quad \$$ outside world

kcode 10001.020100

$\begin{array}{llllll}\text { ksrc } & 0.000 & 0.000 & 0.000 & \$ \text { plutonium solution }\end{array}$

m1 $94239.55 \mathrm{c}-0.44266$ \$ plutonium solution

$94240.50 \mathrm{c}-0.01383$

$94241.50 \mathrm{c}-0.00461$

$1001.50 \mathrm{c}-0.05339$

$8016.50 \mathrm{c}-0.48553$

$\mathrm{mt1}$ lwtr.01t

$\mathrm{m} 2 \quad 1001.50 \mathrm{c} \quad 0.66667 \quad \$$ reflector water

$8016.50 \mathrm{c} \quad 0.33333$

mt2 lwtr.01t $\$ 300 \mathrm{~K}=27 \mathrm{C}=80.6 \mathrm{~F}$ 
totnu

ctme 480 .

print 304060110126

\section{pu_sph2.inp Oxide density $2.00 \mathrm{~g} / \mathrm{cm}^{3}$, sphere case}

message:

Sphere, $4500 \mathrm{~g} \mathrm{Pu}, 1.764 \mathrm{~g} \mathrm{Pu} / \mathrm{cm} 3,2.00 \mathrm{~g} \mathrm{PuO} 2 / \mathrm{cm} 3,2.825 \mathrm{~g} / \mathrm{cm} 3$

c -dens $\mathrm{xx}-\mathrm{xx}$ yy $-\mathrm{yy} \mathrm{zz}-\mathrm{zz}$ rr $-\mathrm{rr} \$$ Comments

$11 \frac{-2.82548}{1}-1$

$22-1.000 \quad 1 \quad-2$

$30 \quad 2 \quad$ imp: $n=0 \$$ outside world

imp:n=1 $\$$ fuel inside hemisphere imp: $=1 \$$ water reflector

1 so $8.47644 \quad \$$ scrap hemisphere radius

2 so $33.47644 \quad \$ 25 \mathrm{~cm}$ water reflection

mode $\mathrm{n}$

tmp 2.585e-8 2r $\quad \$ 001-002300 \mathrm{~K}$ everywhere 1j \$outside world

kcode 10001.020100

$\begin{array}{lllll}\text { ksrc } & 0.000 & 0.000 & 0.000 & \$ \text { plutonium solution }\end{array}$

m1 $94239.55 \mathrm{c}-0.59932 \quad$ \$ plutonium solution

$94240.50 \mathrm{c}-0.01873$

$94241.50 \mathrm{c}-0.00624$

$1001.50 \mathrm{c}-0.03269$

$8016.50 \mathrm{c}-0.34301$

mtl lwtr.01t

m2 $\quad 1001.50 \mathrm{c} \quad 0.66667 \quad$ \$ reflector water

$8016.50 \mathrm{c} \quad 0.33333$

mt2 lwtr.01t $\$ 300 \mathrm{~K}=27 \mathrm{C}=80.6 \mathrm{~F}$

totnu

ctme 480 .

print 304060110126

\section{pu_sph3.inp Oxide density $3.00 \mathrm{~g} / \mathrm{cm}^{3}$, sphere case}

message:

Sphere, $4500 \mathrm{~g} \mathrm{Pu}, 2.646 \mathrm{~g} \mathrm{Pu} / \mathrm{cm} 3,3.00 \mathrm{~g} \mathrm{PuO} 2 / \mathrm{cm} 3,3.738 \mathrm{~g} / \mathrm{cm} 3$

c -dens $\mathrm{xx}-\mathrm{xx}$ yy -yy $\mathrm{zz}-\mathrm{zz}$ rr $-\mathrm{rr} \$$ Comments

$\begin{array}{llll}1 & 1 & -3.73822 & -1\end{array}$

$\begin{array}{lllll}2 & 2 & -1.000 & 1 & -2\end{array}$

3002

1 so 7.40485 \$ scrap hemisphere radius

2 so $32.40485 \quad \$ 25 \mathrm{~cm}$ water reflection imp:n=1 $\$$ fuel inside hemisphere imp: $n=1 \$$ water reflector imp:n=0 $\$$ outside world 
mode $\mathrm{n}$

tmp $\quad 2.585 \mathrm{e}-8 \quad 2 \mathrm{r} \quad \$ 001-002300 \mathrm{~K}$ everywhere $1 \mathrm{j} \quad$ Soutside world

kcode 10001.020100

$\begin{array}{lllll}\text { ksrc } & 0.000 & 0.000 & 0.000 & \$ \text { plutonium solution }\end{array}$

m1 $94239.55 \mathrm{c}-0.67949$ \$ plutonium solution

$94240.50 \mathrm{c}-0.02123$

$94241.50 \mathrm{c}-0.00708$

$1001.50 \mathrm{c}-0.02210$

$8016.50 \mathrm{c}-0.27011$

$\mathrm{mt} 1$ 1wtr.01t

$\mathrm{m} 2 \quad 1001.50 \mathrm{c} \quad 0.66667 \quad$ \$ reflector water

$8016.50 \mathrm{c} \quad 0.33333$

mt2 lwtr.01t $\$ 300 \mathrm{~K}=27 \mathrm{C}=80.6 \mathrm{~F}$

totnu

ctme 480 .

print 304060110126

\section{pu_sph4.inp Oxide density $4.00 \mathrm{~g} / \mathrm{cm}^{3}$, sphere case}

message:

Sphere, $4500 \mathrm{~g} \mathrm{Pu}, 3.528 \mathrm{~g} \mathrm{Pu} / \mathrm{cm} 3,4.00 \mathrm{~g} \mathrm{PuO} 2 / \mathrm{cm} 3,4.651 \mathrm{~g} / \mathrm{cm} 3$

c -dens $\mathrm{xx}-\mathrm{xx}$ yy -yy $\mathrm{zz}-\mathrm{zz}$ rr $-\mathrm{rr} \$$ Comments

$1 \quad 1-4.65096-1$

$\begin{array}{lllll}2 & 2 & -1.000 & 1 & -2\end{array}$

$30 \quad 2 \quad$ imp: $n=0 \$$ outside world

imp: $n=1 \$$ fuel inside hemisphere

imp: $n=1 \$$ water reflector

1 so 6.72775 \$ scrap hemisphere radius

2 so $31.72775 \quad \$ 25 \mathrm{~cm}$ water reflection

mode $n$

tmp $2.585 \mathrm{e}-8 \quad 2 \mathrm{r} \quad \$ 001-002300 \mathrm{~K}$ everywhere

$1 \mathrm{j} \quad \$$ outside world

kcode 10001.020100

$\begin{array}{lllll}\text { ksrc } & 0.000 & 0.000 & 0.000 & \$ \text { plutonium solution }\end{array}$

$\mathrm{ml} \quad 94239.55 \mathrm{c}-0.72818$ \$ plutonium solution

$94240.50 \mathrm{c}-0.02276$

$94241.50 \mathrm{c}-0.00759$

$1001.50 \mathrm{c}-0.01566$

$8016.50 \mathrm{c}-0.22581$

mt1 lwtr.01t

m2 $\quad 1001.50 \mathrm{c} \quad 0.66667 \quad$ \$ reflector water

$8016.50 \mathrm{c} \quad 0.33333$

mt2 lwtr.01t $\$ 300 \mathrm{~K}=27 \mathrm{C}=80.6 \mathrm{~F}$

totnu

ctme 480. 
print 304060110126

pu_sph5.inp Oxide density $5.00 \mathrm{~g} / \mathrm{cm}^{3}$, sphere case

message:

Sphere, $4500 \mathrm{~g} \mathrm{Pu}, 4.410 \mathrm{~g} \mathrm{Pu} / \mathrm{cm} 3,5.00 \mathrm{~g} \mathrm{PuO} 2 / \mathrm{cm} 3,5.564 \mathrm{~g} / \mathrm{cm} 3$
c -dens $\mathrm{xx}-\mathrm{xx}$ yy $-\mathrm{yy} \mathrm{zz}-\mathrm{zz} \mathrm{rr}-\mathrm{rr} \$$ Comments
$\begin{array}{lllll}1 & 1 & -5.5637 & -1\end{array}$
$\begin{array}{lllll}2 & 2 & -1.000 & 1 & -2\end{array}$
$\begin{array}{llll}3 & 0 & 2 & \text { imp:n=0 }\end{array}$ outside world imp:n=1 \$ fuel inside hemisphere imp: $n=1 \$$ water reflector

1 so 6.24549 \$ scrap hemisphere radius

2 so $31.24549 \quad \$ 25 \mathrm{~cm}$ water reflection

mode $\mathrm{n}$

tmp $\underset{1 \mathrm{j}}{2.585 \mathrm{e}-8} 2 \mathrm{r} \underset{\text { \$ outside world }}{\$ 001-002} 300 \mathrm{~K}$ everywhere

kcode 10001.020100

$\begin{array}{lllll}\text { ksrc } & 0.000 & 0.000 & 0.000 & \$ \text { plutonium solution }\end{array}$

$\mathrm{ml} \quad 94239.55 \mathrm{c}-0.76090 \quad$ \$ plutonium solution

$94240.50 \mathrm{c}-0.02378$

$94241.50 \mathrm{c}-0.00793$

$1001.50 \mathrm{c}-0.01134$

$8016.50 \mathrm{c}-0.19605$

$\mathrm{mt1} 1 \mathrm{wtr} .01 \mathrm{t}$

$\mathrm{m} 2 \quad 1001.50 \mathrm{c} \quad 0.66667 \quad$ \$ reflector water

$8016.50 \mathrm{c} \quad 0.33333$

mt2 lwtr.01t $\$ 300 \mathrm{~K}=27 \mathrm{C}=80.6 \mathrm{~F}$

totnu

ctme 480 .

print 304060110126 
HNF-3908 Rev. 0

This page intentionally left blank 


\section{APPENDIX F. CORRESPONDENCE}

Reference Title Page

Nirider, $1997 \quad$ Vertical Calcine Product Tap Densities. ..................... F-3

Compton, 1999a Minimum Calcine Density Expected. . . . . . . . . . . . . . . . . . F -5

Compton, 1999b Maximum Calcine Density Expected. ..................... F-6

Compton, 1999c Product Pu Density Tracking in the Prototype Vertical Calciner. . . . . . . . . . . F-7

Compton, 1999d Plutonium Dioxide Non-Dissolution in Pure Nitric Acid. . . . . . . . . . . F-8

Compton, 1999e Actual Volume Determination for Nominal 4-Liter Narrow Mouth

Polybottles. .........................

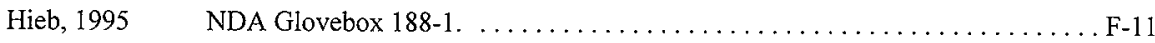


HNF-3908 Rev. 0

This page intentionally left blank 
Author: Laurren $T$ (Tom) Nirider at $\sim$ HANFORD03B

Date: 3/18/97 8:50 AM

Priority: Normal

TO: Karl E Hillesland at - HANFORD07A

Subject: Vertical Calciner Product Tap Densities

Message Contents

I have reviewed the lab notebook and lab analysis results regarding our product samples from the vertical calciner for runs to date. It would be stretching things a bit to say we're definitely at an asymptote on the tap density of piutonium in the produet. I am attaching the Lotus 1-2-3 files with my tables and graph to show the Pu tap densities over time. The last entry for Pu tap density is clearly higher than what had started to look a bit like an asymptote, so I can't really say we've peaked. Nonetheless, I still don't think we're going to exceed $5 \mathrm{gm}$ Pu per cc.by much, if at all. Our latest result of $4.75 \mathrm{gm} \mathrm{Pu} / \mathrm{cc}$ was, no doubt, assisted by having been reroasted powder from an earlier run whose product had a high loss on ignition. The highest Pu tap density without reroasting is only 4.26.

One other point needs to be made and is not shown in the 1-2-3 table anached. We started with a pretty impure $\mathrm{PuO} 2$ bed and have increased the Pu fraction in the bed significantly. In other words, the Pu fraction and, therefore, the Pu density started low partly because the bed was fairly loaded with impurities. As we fed more and more reasonably pure PUREX and PRF solutions through the calciner, the $\mathrm{Pu}$ fraction in the bed increased. That fraction started around 0.75 and is now up to 0.855 as of the last sample results. The theoretical maximum Pu fraction is 0.882 , so we won't be getting much higher. As we reach our asymptote on the Pu fraction, that factor will stop assisting the increase in Pu tap density. Please remember that the production calciner will have occasional batches of impure feeds that will lower its product $\mathrm{Pu}$ fraction and Pu tap density.

We clearly need to continue running the calciner to see where the Pu tap density stops, among other reasons. We plan to do so as soon as the administrative hold on fissile material handling is lifted. I still don't believe we'll exceed $5.0 \mathrm{gm} \mathrm{Pu} / \mathrm{cc}$ consistently and I'm even more certain we won't reach $5.5 \mathrm{gm} \mathrm{Pu} / \mathrm{cc}$. 
Pu Tap Density Tracking

gm Pu/cc (notgm PuO2/cc)

Cumulative Pu Tap

Run \# Prod. $(\mathrm{kg})$ Dens $(\mathrm{gm} / \mathrm{c}$

c)

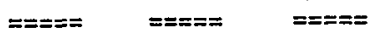

Pu-7

$1.45 \quad 2.77$

PP-01

$2.48 \quad 2.97$

PP-01

$3.48 \quad 3.37$

PP-02

$3.5 \quad 3.27$

$P P-03$

$4.62 \quad 3.98$

PP-05

$6.8 \quad 4.04$

PP.06

7.69

4.04

PP-07

8.54

4.26

Post

8.54

4.75

Pu Tap Densities

Vertical Calciner

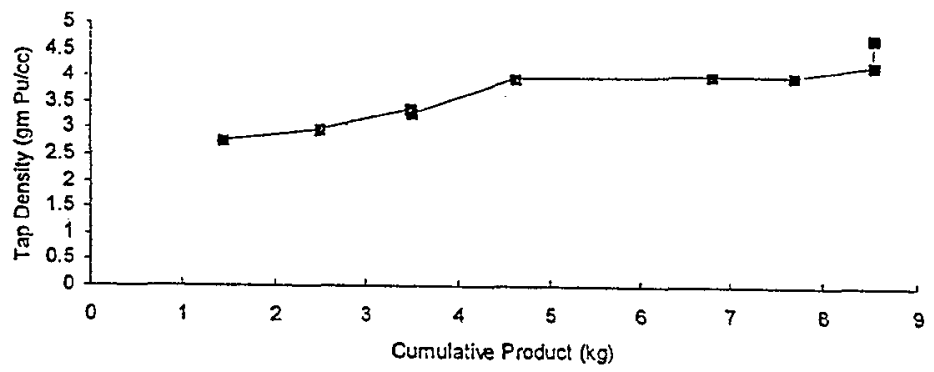

$-2-P u$ Tap Density 


\section{MINIMUM CALCINE DENSITY EXPECTED}

\section{-----Original Message----- \\ From: Compton, James A}

Sent: Monday, January 25, 1999 11:31 AM

To: Miller, Edward M; Dobbin, Kenneth D

Subject: Minimum Calcine Density Expected

Background: I have looked through as many references as I could find and only the old flowsheet document for the old RMA Line (RHO-CD-616) contained the only references to low densities of $\mathrm{PuO}_{2}$ from a calciner. The RMA Line had 2 separate stages of calcining to complete the conversion from damp oxalate to dry oxide. According to the flowsheet, the oxalate filter cake entered the first calciner with a density of $1.58 \mathrm{gm} / \mathrm{cc}$. The incompletely converted oxide left the first calciner at a density of $2.0 \mathrm{gm} / \mathrm{cc}$. The oxide left the second calciner with a density of $2.4 \mathrm{gm} / \mathrm{cc}$. I don't know if the density of $2.0 \mathrm{gm} / \mathrm{cc}$ is from experiments or a split-the-difference assumption.

Answer: I very strongly doubt that we'd be able to produce oxide from our calciner with a density lower than $2.0 \mathrm{gm} / \mathrm{cc}$. I think it will be difficult to produce oxide with a density lower than $2.5 \mathrm{gm} / \mathrm{cc}$ in our calciner. First, the direct denitration process produces crystals with a higher density than crystals from the oxalate process, so partially converted product should be no lower than $2.0 \mathrm{gm} / \mathrm{cc}$.

Second, the oxide we make at any given time is mixed with an existing powder bed of already dense oxide ( $>4 \mathrm{gm} / \mathrm{cc}$ ). Normally, the bed would be at most $1 / 4$ new oxide. I can easily see decreasing the amount of starting bed such that the product in the calciner would be a half-half mixture. In that case, the bed density would be at least $3 \mathrm{gm} / \mathrm{cc}$. In reality, some of the new powder will be heated beyond initial conversion by the time the last of the feed batch is fed to the calciner, so the density should be higher yet.

I think that a product density of $2.75 \mathrm{gm} / \mathrm{cc}$ should be acceptably conservative for the minimum $\mathrm{PuO} 2$ density in any powder that might escape from the calciner. An assumed density of $2.5 \mathrm{gm} / \mathrm{cc}$ should be totally "audit-proof," given the process we're using, the temperature of the bed where the feed is entering, and the speed of conversion in a bed that hot. 


\section{MAXIMUM CALCINE DENSITY EXPECTED}

-----Original Message-----

From: Compton, James A

Sent: Monday, January 25, 1999 12:23 PM

To: Miller, Edward M; Dobbin, Kenneth D

Subject: Maximum Calcine Density Expected

The maximum calcine bulk density that I would expect is considerably lower than recent suggestions of $8.0 \mathrm{gm} / \mathrm{cc}$ (elemental Pu density, not PuO2 density). The maximum density should occur with spherical particles piled up with their centers alternating such that the lowest points of one layer are slightly lower than the highest points of the layer beneath and the highest points are slightly higher than the lowest points of the layer above. As such, the comparison of volumes between a sphere (4/3)(pi)(R-cubed) and a cube (D-cubed or 8 R-cubed) can't be made directly. The amount of overlap between layers can be read from Table 1-20 on page 1-27 of the 6th edition of The Chemical Engineer's Handbook (Perry \& Green, McGraw-Hill, 1984). That overlap is 0.013 of the sphere's volume at both the top and bottom of each layer of spheres. The volume actually occupied by these spheres is then

$$
[(4 / 3)(\mathrm{pi}) / 8]+(2)(0.013)=0.550 \text { of the total volume of space. }
$$

The theoretical density of the crystals of $\mathrm{PuO} 2$, not taking interstitial spaces into account, is 11.46 $\mathrm{gm} / \mathrm{cc}$ (Katz \& Seaborg, The Chemistry of the Actinide Elements, Methuen \& Company, Ltd., 1957, page 279, Table 7.20). These data yield a theoretically maximum bulk density of $\mathrm{PuO} 2$ powder of $(0.55)(11.46 \mathrm{gm} / \mathrm{cc})=6.30 \mathrm{gm} / \mathrm{cc}$. If the powder crystals are pure PuO2, then the elemental Pu density is $(0.882)(6.30)=5.56 \mathrm{gm} / \mathrm{cc}$. Assuming that the listed theoretical density of $11.46 \mathrm{gm} / \mathrm{cc}$ is accurate for directly denitrated $\mathrm{PuO} 2$ and not $\mathrm{PuO} 2$ from some other process, then we should not be able to get higher than an elemental Pu density of $5.56 \mathrm{gm} / \mathrm{cc}$. 


\section{PRODUCT PU DENSITY TRACKING IN THE PROTOTYPE VERTICAL CALCINER}

Bulk density of the elemental plutonium in the product $\mathrm{PuO}_{2}$ powder is one parameter that must be controlled for criticality safety in the prototype vertical calciner. The elemental $\mathrm{Pu}$ density in the product is not the same as the overall powder bulk density, which includes the oxygen content of the $\mathrm{PuO}_{2}$ and any impurities. This density is measured two ways. Officially, the bulk density of the powder is requested as an analysis when powder samples are sent to the PFP Analytical Laboratory. The determination is done per procedure ZL-510-335, "Tap Density of Bulk Solids." The tap density is a bit more dense than the bulk density, which means that the actual powder density inside the powder bed is slightly less than what we calculate from the tap density. Calorimetry of the canned product and the measured net weight of powder inside the product can are then used to calculate the fraction of powder that is elemental $\mathrm{Pu}$. This fraction is then multiplied by the overall powder's bulk density to obtain the elemental Pu density.

A faster unofficial method that the calciner working crew can perform while the powder is still inside the glovebox is also available. A $10-\mathrm{mL}$ graduated cylinder is kept in the product handling area of the calciner glovebox. This cylinder may be partially filled with powder. The volume and net weight of the powder are obtained. The overall powder bulk density is calculated from those data. That density is multiplied by the elemental $\mathrm{Pu}$ fraction in the last reported batch of product to estimate the current elemental Pu density. This method assumes that the density is changing relatively slowly and is fairly consistent throughout the powder bed, allowing the working crew to stop before the density limit is exceeded. If there is any doubt about the elemental $\mathrm{Pu}$ fraction in the product, a value of 0.88 is used, which is the theoretical maximum for perfectly pure $\mathrm{PuO}_{2}$. The assumption that the density is fairly consistent throughout the powder bed is believed reasonable due to the mixing that occurs in the bed during operation.

The latest known elemental Pu density is recorded on the plutonium inventory sheet, which is kept on the room wall, and in the laboratory notebook to allow tracking. If the limit of $5.5 \mathrm{gm} \mathrm{Pu}$ per cc of product is approached, one of two methods will be implemented to keep from exceeding the limit. One method is to stop testing, obtain a new CSER/CPS/Posting with a higher density limit and any corresponding changes to other limits, then resume testing. This first method could also yield a new CSER/CPS/Posting that eliminates the elemental Pu density limit and substitutes entirely different types of limits. The second method is to begin using "dirtier" feed (i.e., deliberately choose feeds with more impurities or deliberately add impurities to relatively clean feed) to dilute the $\mathrm{Pu}$ in the product powder. The choice between methods will be made in consultation with criticality safety, nuclear safety, and Process Engineering personnel. 


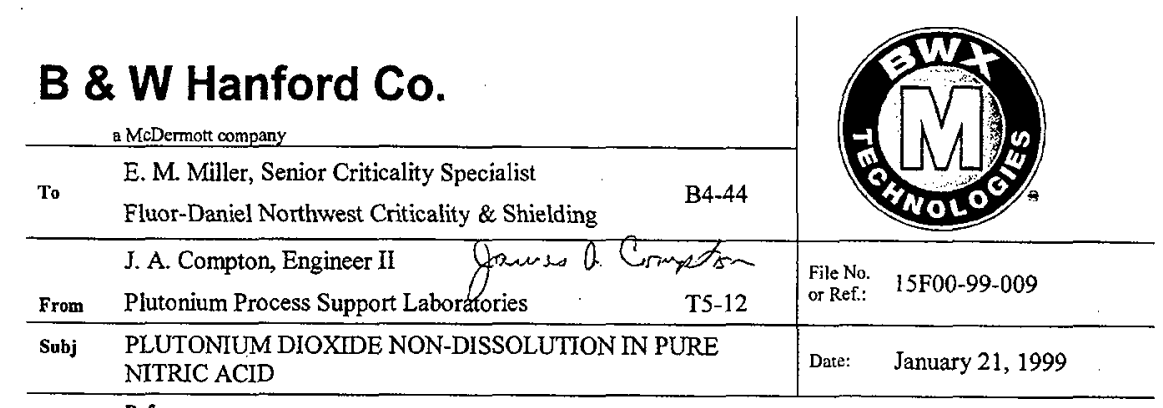

References

ARH-2866, Semicontinuous Dissolution of Plutonium Dioxide, J. V. Panesko, November, 1974 Nuclear Chemistry, Pergammon Press, Great Britain, September, 1976

Criticality safety studies for the prototype vertical calciner need to include the possibility that reasonably pure nitric acid solutions may get mixed with solid plutonium dioxide. The hydrogen in the water and the nitric acid molecules furnishes moderation to the neutrons occurring from radioactive decay of the plutonium. This moderation increases the chance of an accidental criticality. Dissolution of the plutonium dioxide, if it occurs, allows the plutonium to be more dispersed, possibly changing the geometry in addition to the moderation.

The nitric acid solutions to be used in the restart of the prototype vertical calciner will not dissolve the plutonium dioxide to any appreciable extent. Many experiments early in the nuclear industry showed that pure nitric acid was a very ineffective solvent for $\mathrm{PuO}_{2}$. A second chemical, usually hydrofluoric acid or calcium fluoride, had to be added to form a complex with the $\mathrm{Pu}$ and get it into solution. Heat also increased the speed of dissolution. Even this method has its limits as the free fluoride ion concentration decreases. Reference 1 states that a solution of $12 \mathrm{M} \mathrm{HNO}=0.35 \mathrm{M} \mathrm{HF}$ at $90^{\circ} \mathrm{C}$ did most of its dissolving in the first 20 minutes. The rate then decreases rapidly. Reference 2 states that the reason for the decrease in rate is the loss of fee fluoride ion concentration as that ion gets complexed to make the $\mathrm{Pu}$ soluble. Experiments reported in Reference 2 showed that the dissolution rate drops quickly with both starting fluoride ion concentration and time. Reference 2 also shows that dissolution rates decrease rapidly with decreasing nitric acid concentration and with decreasing temperature.

The solutions to be used in the prototype calciner restarts will not contain any fluoride ions above unavoidable impurity levels in the purchased stock solution. Furthermore, these solutions 
E. M. Miller

\section{Page 2}

January $2 \mathbf{i}, 1999$

will use nitric acid concentrations that are considerably more dilute than solutions normally used for dissolving $\mathrm{PuO}_{2}$ (0.5-1.5 $\mathrm{M} \mathrm{HNO}_{3}$ vs. 10-12 $\mathrm{M}$ ). Finally, these solutions will be at room temperature. If large quantities of these nitric acid solutions get mixed with large quantities of $\mathrm{PuO}_{2}$, there will be only a very small amount of dissolution that can occur and it will occur at extremely slow rates.

jac 


\section{B \& W Hanford Co.}

a McDermott company

\begin{tabular}{|c|c|c|}
\hline \multicolumn{2}{|c|}{ a McDermott company } & 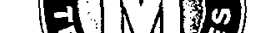 \\
\hline \multirow{2}{*}{ To } & E. M. Miller, Senior Criticality Specialist & \\
\hline & Fluor-Daniel Northwest Criticality \& Shielding & \\
\hline From & $\begin{array}{l}\text { J. A. Compton, Engineer II } \\
\text { Plutonium Process Support Laboratories }\end{array}$ & $\begin{array}{l}\text { File No. } \quad 15 F 00-99-006 \\
\text { or Ref:: }\end{array}$ \\
\hline Subj & $\begin{array}{l}\text { ACTUAL VOLUME DETERMINATION FOR NOMNAL 4- } \\
\text { LITER NARROW MOUTH POLYBOTTLES }\end{array}$ & January 18,1999 \\
\hline
\end{tabular}

Actual volumes and nominal (advertised) volumes of polyethylene bottles are not identical. For purposes of accuracy within criticality safety evaluations, the actual volume of a nominal 4-L narrow-mouthed polybottle was determined on January 13. An empty 4-L polybottle was tare weighed on an electronic balance and the tare weight reset to zero grams. The bottle was then filled with tap water to the bottom edge of the narrow mouth section on the top of the bottle. The bottle was reweighed with a net weight of 4,147 grams of water. At $1.00 \mathrm{gm} / \mathrm{mL}(1.00$ $\mathrm{kg} / \mathrm{L}$ ), the volume for this weight of water is $4.147 \mathrm{~L}$. The volume of the narrow mouth section that was not filled is no more than $30 \mathrm{~mL}$, so the total volume this bottle could contain is just below 4.20 L. The Plutonium Process Support Laboratories recommend that an actual volume of $4.20 \mathrm{~L}$ be used for criticality studies involving use of these bottles.

Volume determinations for 4-L wide-mouthed polybottles or bottles made of any other materials were not made and are expected to be different from the volume of a 4-L narrow mouth polybottle.

jac. 
Westinghouse

Internal

Hanford Company

Memo

$\begin{array}{lll}\text { From: } & \text { PFP Ana]ytical Laboratory } & \text { 15400-95-043 } \\ \text { Phone: } & 373-2211 \text { T5-05 } & \\ \text { Date: } & \text { June 6, 1995 } \\ \text { Subject: } & \text { NDA GLOVEBOX 188-1 }\end{array}$

To:

C. S. Sutter

T5-12
cc: J. A White T5-12
C. R. Stalibaum T5-05
NDA File
EWC:LB File

On June 5, 1995, glovebox 188-1 was assayed for residual piutonium content. This assay was completed by $D$. L. Sorenson using portabie Nal detector 600 . The plutonium value for glovebox $188-1$ is 5 grams with a range of 1 to 14 grams.

Should you have any questions regarding this assay, please contact Cheryl Sta7lbaum on 373-2562 or myself.

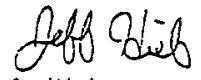

J. Hieb

Team Leader

dis 
HNF-3908 Rev. 0

This page intentionally left blank. 
DISTRIBUTION SHEET

\begin{tabular}{|c|c|c|c|c|c|}
\hline \multirow{2}{*}{$\begin{array}{l}\text { To } \\
\text { DISTRIBUTION }\end{array}$} & \multirow{2}{*}{\multicolumn{3}{|c|}{$\begin{array}{l}\text { From } \\
\text { Criticality and Shielding }\end{array}$}} & \multicolumn{2}{|l|}{ Page 1 of 1} \\
\hline & & & & \multicolumn{2}{|c|}{ Date $02 / 12 / 99$} \\
\hline \multirow{2}{*}{\multicolumn{4}{|c|}{$\begin{array}{l}\text { Project Title/Work Order } \\
\text { CSER 99-001: PFP Lab Denitrating Calciner, Rev. } 0\end{array}$}} & \multirow{2}{*}{\multicolumn{2}{|c|}{ EDT No. 623022}} \\
\hline & & & & & ECN No. $\quad N / A$ \\
\hline Name & MSIN & $\begin{array}{l}\text { Text } \\
\text { With All } \\
\text { Attach. }\end{array}$ & Text Only & $\begin{array}{l}\text { Attach./ } \\
\text { Appendix } \\
\text { Only }\end{array}$ & $\begin{array}{l}\text { EDT/ECN } \\
\text { Only }\end{array}$ \\
\hline
\end{tabular}

B \& W Hanford

J. A. Compton

S. E. Nunn

A. L. Ramble

R. W. Szempruch

M. E. Shaw

C. S. Sutter

T5-12

T5-11

T5-54

T5-48

T5-54

T5-12 $x$
$X$
$x$
$X$
$x$
$x$

$\begin{array}{ll}\text { B4-44 } & X \\ \text { B4-44 } & X \\ \text { B4-44 } & X \\ \text { B4-44 } & X \\ \text { B4-45 } & X \\ \text { B4-45 } & X \\ \text { B4-44 } & X \\ \text { B4-44 } & X \\ \text { T5-50 } & X \\ \text { B4-44 } & X \\ \text { B4-43 } & X\end{array}$

Fluor Daniel Northwest

K. D. Dobbin

D. G. Erickson

J. P. Estrell ado, Jr.

J. Greenborg

L. L. Reetz(3)

D. S. Leach

E. M. Miller

R. F. Richard

G. L. Rippy

W. D. Wittekind

D. W. Wootan

Central Files (Orig. + 2) Docket Files (2 copies)
$\begin{array}{ll}\mathrm{B} 1-07 & \mathrm{X} \\ \mathrm{A} 3-02 & \mathrm{X}\end{array}$

DOE READING ROOM

H2-53 $\quad x$

$K N$ 